\title{
Tatiana Duobles
}

\section{Análise da influência da microglia mutante na sobrevida do neurônio motor no modelo in vitro da esclerose lateral amiotrófica utilizando camundongos transgênicos para SOD1 humana}

Tese apresentada à Faculdade de Medicina da Universidade de São Paulo para obtenção do título de Doutor em Ciências

Programa: Neurologia

Orientador: Prof. Dr. Gerson Chadi

São Paulo 


\section{Tatiana Duobles}

\section{Análise da influência da microglia mutante na sobrevida do neurônio motor no modelo in vitro da esclerose lateral amiotrófica utilizando camundongos transgênicos para SOD1 humana}

Tese apresentada à Faculdade de Medicina da Universidade de São Paulo para obtenção do título de Doutor em Ciências

Programa: Neurologia

Orientador: Prof. Dr. Gerson Chadi

São Paulo 


\section{Dados Internacionais de Catalogação na Publicação (CIP)}

Preparada pela Biblioteca da

Faculdade de Medicina da Universidade de São Paulo

Creprodução autorizada pelo autor

\section{Duobles, Tatiana}

Análise da influência da microglia mutante na sobrevida do neurônio motor no modelo in vitro da esclerose lateral amiotrófica utilizando camundongos transgênicos para SOD1 humana / Tatiana Duobles. -- São Paulo, 2013.

Tese (doutorado)--Faculdade de Medicina da Universidade de São Paulo.

Programa de Neurologia.

Orientador: Gerson Chadi.

Descritores: 1.Esclerose amiotrófica lateral 2.Microglia 3.Neurônios motores 
Dedicatória

Aos meus pais pelo amor, apoio e incentivo. 


\section{AGRADECIMENTOS}

À D'us que me deu forças para realizar esse trabalho e colocou em meu caminho pessoas especiais que puderam colaborar em todas as etapas.

Ao Prof. Dr. Gerson Chadi pela oportunidade, pela idealização deste grande projeto temático em ELA e pela orientação segura.

Aos meus pais que me apoiaram em todos os sentidos, me encorajam em todos os momentos em me ensinaram a sempre agir com honestidade, humildade e força. Sem esse apoio não teria como realizar esse trabalho.

Aos meus avôs Szaja e Tojba, Dora e Luiz pelo exemplo de vida.

Ao meu irmão Gilberto pela cumplicidade, incentivo e apoio.

Ao Fernando, meu namorado, pelo carinho, paciência, apoio, compreensão, dedicação e encorajamento.

Aos meus tios e primos que mesmo de longe, sempre se preocuparam com $o$ andamento desse trabalho e meu futuro profissional.

À Juliana Scorisa, amiga e companheira de trabalho por ter me feito rir nas horas difíceis e estado presente em todos os setores da minha vida, me deu seu ombro e acompanhou todas as etapas desse trabalho, o qual não teria sido concluído sem seu apoio.

À Gabriela Pintar de Oliveira pelo apoio e por compartilhar resultados, experimentos, incentivo, conversas pessoais e profissionais que foram essenciais desde o início.

À Dra. Jéssica pela disposição, ajuda e pela convivência de tantos anos onde crescemos, aprendemos e nos apoiamos.

À Florence pelas lições que levarei para a vida, conselhos, fofocas e amizade.

Ao Gilmar e Sarah pela gentileza, ajuda e constante dedicação.

Aos colegas Chary, Thais Moura, Chrysthian, Allan Fappi, Juliana Neves e Vanessa pela compreensão, ajuda e descontração nas horas vagas.

Às meninas Re's, Fe e Larissa pela compreensão, momentos de descontração e desabafo.

À Juliana Costa pela confiança, amizade e força. 
À Profa. Dra. Debora Fior Chadi e Profa. Dra. Vânia Gomide pelas considerações na qualificação.

À pós graduação da neurologia da Faculdade de Medicina da Universidade de São Paulo.

À FAPESP (2008/10798-1) pela oportunidade em prover a bolsa de estudo.

À FAPESP (2010/20457-7) e CNPq pelo apoio financeiro. 


\section{Epígrafe}

"Mesmo quando tudo parece desabar, cabe a mim decidir entre rir ou chorar, ir ou ficar, desistir ou lutar; porque descobri, no caminho incerto da vida, que o mais importante é decidir" Cora Coralina 
Esta tese está de acordo com as seguintes normas, em vigor no momento desta publicação:

Referências: adaptado de International Committee of Medical Journals Editors (Vancouver).

Universidade de São Paulo. Faculdade de Medicina. Divisão de Biblioteca e Documentação. Guia de apresentação de dissertações, teses e monografias. Elaborado por Annelise Carneiro da Cunha, Maria Julia de A. L. Freddi, Maria F. Crestana, Marinalva de Souza Aragão, Suely Campos Cardoso, Valeria Vilhena. 3a Ed. São Paulo: Divisão de Biblioteca e Documentação; 2011.

Abreviaturas dos títulos dos periódicos de acordo com List $f$ Journals Indexed in Index Medicus 


\section{Sumário}

LISTA DE ABREVIATURAS, SÍMBOLOS E SIGLAS .................................

LISTA DE FIGURAS.............................................................. IV

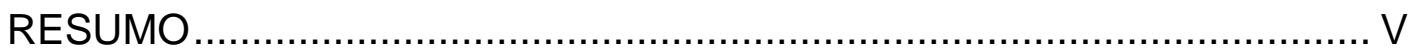

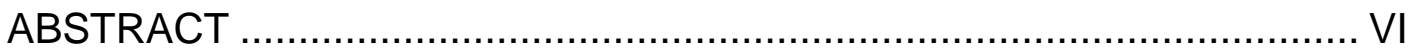

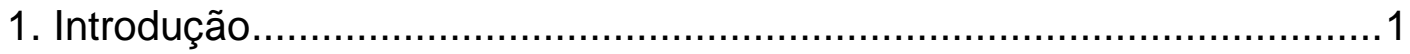

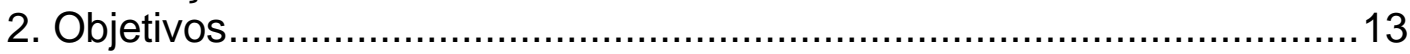

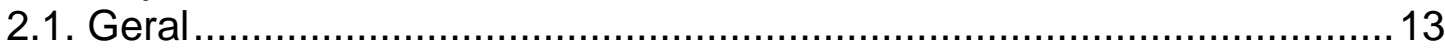

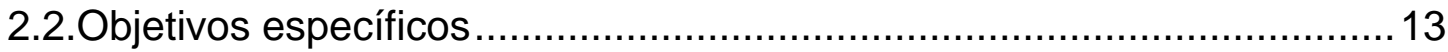

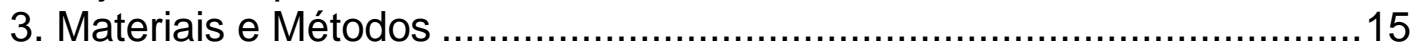

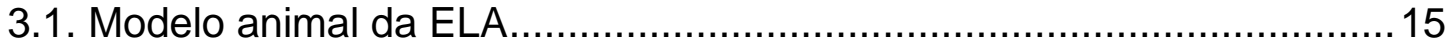

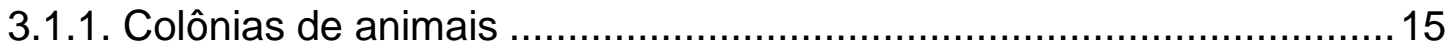

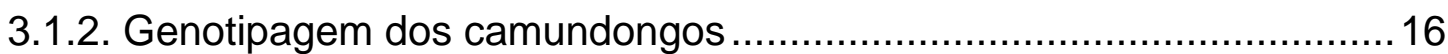

3.2. Culturas primárias de células ………............................................18

3.2.1. Cultura de neurônios motores .....................................................19

3.2.2. Cultura de microglia obtida a partir de camundongo neonato em $P 1$.. 20

3.2.3. Cultura de microglia obtida a partir do camundongo adulto pré-

sintomático em P60 ...........................................................................21

3.3. Determinação da pureza das culturas primárias ................................22

3.3.1. Imunoperoxidase e imunofluorescência .........................................22

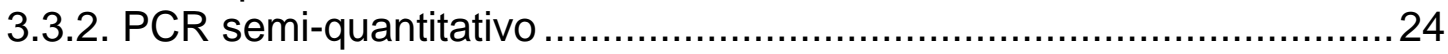

3.4. Estabelecimento da co-cultura neurônio/microglia ...............................25

3.5. Ativação microglial com LPS e avaliação de seu estado ativo ................25

3.6. Análise do estado trófico do neurônio na presença do meio condicionado de microglia ....................................................................26

3.7. Análise da morte neuronal em co-culturas neurônio/microglia ...............27

3.8. Presença de marcador de degeneração neuronal:.................................28

3.8.1. Presença de marcador de degeneração neuronal nos neurônios submetidos a tratamento com meio condicionado microglial.........................28 3.8.2. Presença de marcador de degeneração neuronal nos sistemas de

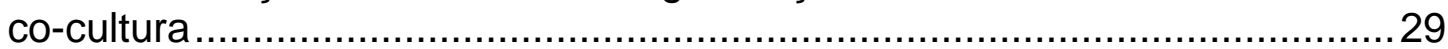

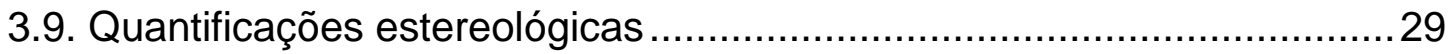

3.9.1.Quantificações estereológicas em contraste de fase nas células sob tratamento de meio condicionado ............................................................29

3.9.2. Quantificação estereológica para a pureza das culturas .......................30

3.9.3. Quantificações estereológicas em microscópio de fluorescência da morte neuronal provocada pelo tratamento com meio condicionado .............30

3.10. Seleção das moléculas do estudo ....................................................31

3.11. Quantificação de moléculas secretadas no meio condicionado

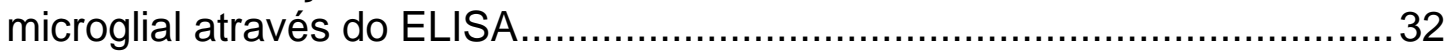

3.12. Extração e amplificação do RNA das culturas microgliais ....................33

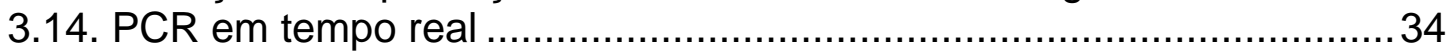

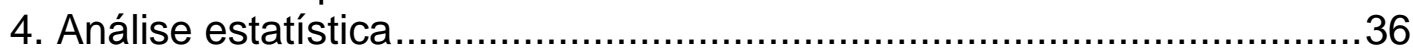

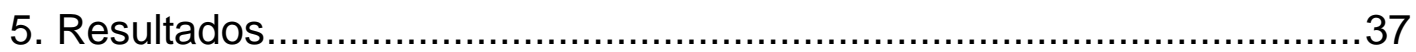

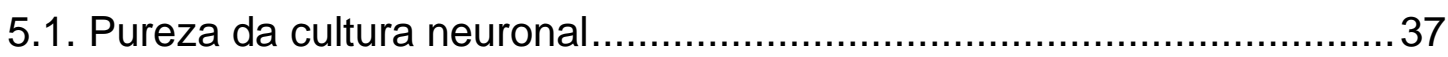

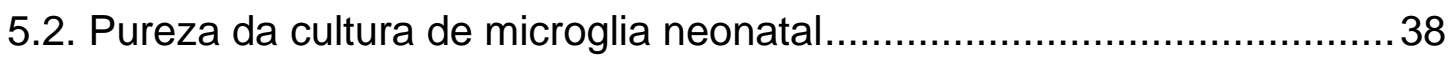

5.3. Pureza da microglia proveniente do camundongo adulto ........................40 
5.4. Análise do trofismo do neurônio na presença do meio condicionado de microglia sem ativação pelo LPS.

5.5. Ativação microglial com LPS e avaliação de seu estado ativo ................42 42

5.6. Análise do trofismo do neurônio na presença do meio condicionado de microglia com ativação do LPS

5.7. Presença de marcador de degeneração neuronal nos neurônios submetidos ao tratamento com meio condicionado de miroglias ativadas pelo LPS

5.8. Análise da morte neuronal em co-culturas neurônio/microglia ...............46

5.9. Seleção das moléculas a partir dos resultados do microarray .................48 48

5.10. Quantificação das moléculas candidatas no meio condicionado microglial através da técnica de ELISA

5.11. Quantificação da expressão gênica pela microglia cultivada através da técnica de PCR em tempo real

6. Discussão

6.1. Pureza das culturas de células....

6.2. Análise do trofismo do neurônio na presença do meio condicionado de microglia

6.3.Análise da morte neuronal em co-culturas neurônio/microglia .................57

6.4. Quantificação das moléculas candidatas no meio condicionado microglial através da técnica de ELISA

6.5. Quantificação da expressão gênica microglial através da técnica de

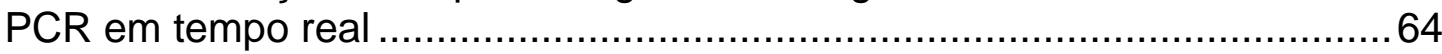

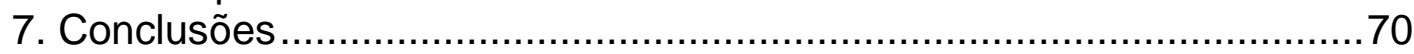

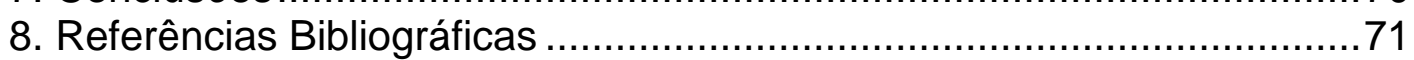

ANEXO A- Aprovação do Comitê de ética em pesquisa ...........................95

ANEXO B- Moléculas selecionadas a partir dos resultados do microarray para quantificação no MC microglial.

ANEXO C- Genes selecionados a partir dos resultados do microarray para quantificação da expressão gênica nas microglias.......................................101

ANEXO D- Artigo submetido para a revista BMC Neuroscience ..............104 


\section{LISTA DE ABREVIATURAS, SÍMBOLOS E SIGLAS}

AA- Do inglês, Areal fraction

ALS- Do inglês, Amyotrophic lateral sclerosis

AKAP13- Do inglês, A-kinase anchor protein 13

BSA- Do inglês, Bovin serum albumin

cDNA- Do inglês, DNA complementar

ChAT- Do inglês, Choline actetyltransferase

COX-2- Ciclo-oxigenase 2

CNTF- Do inglês, Ciliary neurotrophic factor

DMEM- Meio Dubbelco MEM

DNA- Do inglês, Deoxyribonucleic acid

EDTA-Do inglês, Ethylenediamine tetraacetic acid

ELA- Esclerose lateral amiotrófica

ELISA- Do inglês, Enzyme-linked immunosorbent assay

ET-1- Endotelina-1

GDNF- Do inglês, Glial cell line-derived neurotrophic factor

GFAP- Do inglês, Glial Fibrillary Acidic Protein

HIPK3- Do inglês, Homeodomain-interacting protein kinase 3

IGF- Do inglês, Insulin like growth factor

IGFBP- Do inglês, IGF binding protein

IL-2- Interleucina 2

IL-6- Interleucina 6

IL- $\beta$ - Interleucina $\beta$

LPS- Lipopolisacarídeo

MC- Meio condicionado

mg- Miligrama

ml- Mililitro

mm- Milímetro 
mM- Milimolar

mTG P1- Microglia transgênica proveniente de camundongo de 1 dia mTG P60- Microglia transgênica proveniente de camundongo de 60 dias mWT P1- Microglia wild type proveniente de camundongo de 1 dia mWTP60- Microglia wild type proveniente de camundongo de 60 dias NF-K $\beta$ - Do inglês, Nuclear factor kappa $\beta$ ng- Nanograma

NGF- Do inglês, Nerve growth factor

nm- Absorbância

nM- Nanomolar

NO- Do inglês, Nitric oxide

PBS- Do inglês, Phosphate buffered saline

PCR- Do inglês, Polymerase chain reaction

PDO- Poli D Ornitina

pg- Picograma

PLL- Poli L Lisina

RNA- Do inglês, Ribonucleic acid

RNAi- RNA de interferência

SFB- Soro fetal bovino

SNC- Sistema nervoso central

SOD1- Superóxido dismutase 1

SOD1m- Superóxido dismutase 1 mutante

Spf- Do inglês, specif pathogen free

SUMO- Do inglês, Small Ubiquitin-like Modifier

TG- Transgênico

TLR-2- Do inglês, Toll-like receptor2

TNFa- Fator de necrose tumoral $\alpha$

VEGF- Do inglês, Vascular endothelial growth factor

WT- Do inglês, wild-type 
$\mu \mathrm{l}$ - Microlitro

$\mu g$ - Micrograma

${ }^{\circ} \mathrm{C}$ - Graus Celsius

$<-$ Menor

> - Maior

a-Alfa

$\beta$ - Beta

ү- Gama 


\section{LISTA DE FIGURAS}

Figura 1. Procedimento para determinar o genótipo dos camundongos TG e WT

Figura 2. Imagem da cultura microglial neonatal marcada com lba-1 em marrom e GFAP em azul

Figura 3. Histograma demonstrando a pureza da cultura de microglia neonatal

Figura 4. Imagem de gel de agarose mostrando a expressão do RNA através das bandas: GAPDH, GFAP e Cd11b

Figura 5. Imagem da cultura microglial proveniente de animal adulto marcada com lba-1 em marrom e GFAP em azul

Figura 6. Gráfico ilustrando a população de células na cultura microglial proveniente de animal adulto

Figura 7. Imagem de culturas de neurônios motores purificadas

Figura 8. Gráfico ilustrando a população de células na cultura de neurônios motores

Figura 9. Gráficos representando a quantificação de prolongamentos e corpos neuronais de cultura de neurônios tratadas com meio neuronal (controle) e microglial

Figura 10. Gráfico com quantidade de NO secretada pelas microglias sem ativação ou através da ativação com 1 ou $10 \mu \mathrm{g} / \mathrm{ml}$ de LPS

Figura 11.Gráficos representando a porcentagem da produção de NO das microglias transgênicas adultas em relação às WT

Figura 12. Gráficos representando a quantificação de prolongamentos e corpos neuronais de cultura de neurônios tratadas com meio neuronal (controle) e meio condicionado microglial ativada com LPS

Figura 13. Imagem ilustrando os neurônios em verde, marcados com FluoroJade $C$, indicando que estão em processo de degeneração 46

Figura 14. Gráficos ilustrando a porcentagem de morte de neurônios WT e TG com os diferentes meios condicionados de microglias neonatais e adultas

Figura 15. Fotomicrografia de co-cultura neurônio/microglia tirada após processo de dupla imunofluorescência

Figura 16. Gráfico representando a média da quantidade de degeneração neuronal causada pelo contato neurônio/microglia neonatal e adulta nos sistemas de co-cultura

Figura 17. Níveis de TNFa, VEGF, IL-6, IGF, NGF, ET-1 dosados pelo método de ELISA sanduíche nos meios condicionados microgliais proveniente de animais neonatais e com 60 dias

Figura 18. Gráficos representando as diferenças de expressão relativa dos diferentes genes AKAP13, HIPK3, UBE2I, NKRF nas microglias cultivadas proveniente de animais neonatais e com 60 dias 


\section{RESUMO}

Duobles, T. Análise da influência da microglia mutante na sobrevida do neurônio motor no modelo in vitro da esclerose lateral amiotrófica utilizando camundongos transgênicos para SOD1 humana [Tese]. São Paulo: Faculdade de Medicina, Universidade de São Paulo; 2012.

A Esclerose Lateral Amiotrófica (ELA) é uma doença progressiva caracterizada pela perda de neurônios motores levando rapidamente os pacientes à morte. Os mecanismos da morte neuronal são desconhecidos e estudos recentes indicam que a microglia pode participar deste processo. Para investigar o papel da microglia na ELA, camundongos transgênicos SOD1 ${ }^{\mathrm{G} 93 \mathrm{~A}}$ foram utilizados na avaliação da morte e do trofismo neuronal em sistemas de co-culturas neurônio/microglia e do efeito do meio condicionado microglial sob os neurônios motores. Ambas as células foram extraídas da medula espinal de camundongos transgênicos (TG) e wild type (WT). A microglia foi obtida dos animais neonatos e adultos na fase pré-clínica da doença. Os neurônios extraídos de neonatos foram marcados com reagente específico para morte neuronal e seus prolongamentos foram quantificados em contraste de fase por métodos estereológicos específicos. A expressão gênica de moléculas candidatas à participação do processo neurodegenerativo relacionadas com a microglia foi quantificada pelo PCR em tempo real, assim como a quantidade de moléculas secretadas no meio condicionado das culturas microgliais dosada pelo ELISA sanduíche. O meio condicionado da microglia TG neonatal não foi capaz de acentuar a morte neuronal, entretanto a neurodegeneração foi potenciada nas análises das co-culturas. Interessantemente, o meio condicionado das microglias WT provenientes de animais adultos foram capazes de aumentar os prolongamentos neuronais feito não observado em relação às microglias TG. Quantidades aumentadas do fator de necrose tumoral $\alpha$, interleucina- 6 e fator de crescimento derivado do nervo foram quantificadas no meio condicionado das microglias TG. A microglia TG neonatal apresentou dimuição na expressão gênica de AKAP13, HIPK3, UBE2I E NTF5. Esses achados precoces sugerem perda de migração microglial, perda de resistência à apoptose, desbalanço entre proliferação e morte celular e diminuição do suporte trófico neuronal. Em conjunto, os resultados evidenciam a participação da microglia nos mecanismos da ELA.

Descritores: Esclerose amiotrófica lateral; microglia; neurônios motores. 


\section{ABSTRACT}

Duobles, T. Analysis of microglial influence on motor neuron death in an in vitro model of amyotrophic lateral sclerosis using SOD1 transgenic mice [Tese]. São Paulo: "Faculdade de Medicina, Universidade de São Paulo"; 2012.

Amyotrophic Lateral Sclerosis (ALS) is a progressive degenerative disorder affecting motoneurons and leading the patient to death.The cause of motor neurons degeneration in ALS is uncertain and there is any treatment able to prolong the patient life. Recent studies show that microglia could participate of the process of ALS degeneration. Its activation is linked to the disbalance of neuroprotective and neurotoxic action. To investigate the microglia role in ALS, SOD1 ${ }^{\mathrm{G} 93 \mathrm{~A}}$ transgenic mice that develop symptoms similar to the clinical disease were used. We evaluated the neuronal death and trophism in microglia/neuron co-cultures system and in microglial conditioned medium effect under the neurons. Neurons and microglia were extracted from transgenicor wild type mice spinal cord. Microglia was obtained from 1 day pos natal pups and adult onset of disease mice. Cells were stained with a specific marker to neuronal death. Neuronal extensions area and neuronal death was quantified by stereological method. The genic expression of candidate molecules related to degeneration in ALS was quantified by real time PCR and the release of some molecules were quantified by ELISA sandwich. Results showed that maybe transgenic neonatal microglia is not able to increase the neuronal death through releasing molecules in its conditionated medium, on the other hand when transgenic microglia was co-cultured with any kind of neuron, neuronal death was observed. Microglia from adult transgenic mice was not able to promote a neuroprotection compared to wild type in co-culture and conditionated medium experiments. In addition to this, was observed increased tumor necrosis factor alpha, interleukin 6 and nerve growth factor secretion by transgenic microglia. Neonatal transgenic microglia also exhibited reduced genic expression of AKAP13, HIPK3, UBE2I and NTF5. These findings at an early stage suggest a lost of migration potential, lost of apoptosis resistance, disbalance of proliferation and cell death and reduction of neuronal trophic support. So together, these data indicate the involvement of microglia in ALS mechanisms.

Descriptors: Amyotrophic lateral sclerosis; microglia; motor neuron. 


\section{Introdução}

Jean Martin Charcot descreveu pela primeira vez em 1869 a morte progressiva de neurônios motores na Esclerose Lateral Amiotrófica (ELA). O nome da doença deriva das observações da coloração pálida da substância branca da medula espinal representada pela degeneração e perda dos axônios motores superiores que se projetam do cérebro e estabelecem conexões diretas ou indiretas com os neurônios motores inferiores da medula espinal (Charcot e Joffroy, 1869).

A ELA é a doença do neurônio motor com início na idade adulta mais comum na sociedade moderna. A doença manifesta-se por volta da segunda ou terceira década de idade pelo declínio linear da função muscular que leva à paralisia, falência respiratória e ao óbito em dois a cinco anos (Mazzini et al., 2008). Os estudos mostram que a incidência e a prevalência da doença são de 1,89 e 5,2 por cem mil habitantes (Boillee et al., 2006).

A forma mais comum da ELA, a esporádica, ocorre em cerca de $90 \%$ dos casos, contrastando com a forma familiar que atinge menos de $10 \%$, estando esta atrelada a uma herança genética caracterizada como autossômica dominante. Sabendo que nas duas formas os mesmos neurônios são afetados e a patologia é similar, há grande interesse nas pesquisas que envolvem os processos inflamatórios e os mecanismos da doença (Ince et al., 1998).

A descoberta marcante de 1993 iniciou a era molecular das pesquisas em ELA. Rosen et al. (1993) identificaram as mutações no gene que codifica para a superóxido dismutase 1 (SOD1) como causadoras de cerca de $20 \%$ dos casos familiares da doença. A SOD1 é uma enzima citosólica cuja função é converter superóxidos, bioprodutos naturais da respiração, em água ou peróxido de hidrogênio (Bruijin, 2004).

Sabe-se que a ação da SOD1 é dependente da atividade catalítica do cobre, íon que necessita da sua chaperona específica para a incorporação. 
O fato do cobre intracelular ser tóxico para o neurônio motor (Wang et al., 2003) levantou a suspeita da mutação na estrutura da SOD1 promover a toxicidade por alteração na incorporação do íon, entretanto os experimentos recentes mostraram que a propriedade tóxica da SOD1 aparece como resultado da mutação da enzima em si e é independente da atividade da dismutase ou da chaperona relacionada e pode ser deflagrada sem a catálise de um sítio ativo de cobre (Wang et al., 2003). De fato, a expressão do gene mutante da SOD1 (SOD1m) em roedores leva à degeneração neuronal como resultado de propriedades tóxicas adquiridas (Gurney et al., 1994; Nagai et al., 2007).

Experimentos realizados com RNA de interferência (RNAi) mostram o retardo na progressão da doença após a redução da expressão do gene SOD1m, o que ressalta a contribuição da proteína mutante na patogênese da ELA (Miller et al., 2005; Ralph et al., 2005). Deste modo, o animal transgênico que carrega a SOD1m é aceito como modelo animal para o estudo da ELA.

Número superior a 150 mutações na SOD1 humana está descrito e mais de 10 linhagens de camundongos foram estabelecidas, sendo que a linhagem SOD $1^{\mathrm{G} 93 A}$ (substituição da glicina pela alanina na posição 93 da cadeia de aminoácidos) é a mais utilizada nos estudos, seguida daquelas linhagens $S O D 1^{\mathrm{G} 85 R}$ e SOD $1^{\mathrm{G} 37 \mathrm{R}}$ (Neusch et al., 2007). Ressalta-se que a maioria dos mecanismos conhecidos sobre a fisiopatologia da neurodegeneração do neurônio motor advem de estudos com estes animais transgênicos (Julien, 2001; Bendotti e Carri, 2004; Julien e Kris, 2006).

Das hipóteses que explicam a degeneração dos neurônios, destacamse aquelas sobre os danos oxidativos, a formação de agregados protéicos, os problemas no transporte axonal, as disfunções mitocondriais e as cascatas inflamatórias (Bruijn, 2004).

O estresse oxidativo foi observado em alguns estudos de ELA através da análise de marcadores bioquímicos em amostras de pacientes pós 
mortem, entretanto, esta hipótese por si não explica a degeneração do neurônio (Kim et al., 2003). O tratamento de pacientes com riluzole, droga capaz de diminuiro influxo de cálio e indiretamente reduzir o estresse oxidativo, não foi capaz de promover efeitos clínicos significativos (Zoccolella et al., 2009).

Os agregados protéicos citoplasmáticos são observados na ELA e em outras doenças neurodegenerativas como o Mal de Alzheimer, a Doença de Parkinson e a doença de Huntington (Watanabe et al., 2001). Na ELA em particular, tais agregados são formados, muitas vezes, por acúmulos anormais de proteínas como o neurofilamento, a periferina (Wong et al., 2000a; Mendonça et al., 2005), a proteína Tar ligante de DNA de $43 \mathrm{kDa}$, também conhecida como TDP43 (Arai et al., 2006), a proteína ligante de RNA fundida no sarcoma, também conhecida como FUS (Kwiatkowski et al., 2009; Vance et al., 2009), a ubiquitina, cujo acúmulo indesejado prejudica a renovação protéica por interferir com a maquinaria proteossômica (Wong et al., 2000b; Wang et al., 2003) e a própria SOD1 (Shaw et al., 2008). Apesar da relação amplamente documentada, a questão da morte dos neurônios motores ser causa ou consequência da formação dos agregados é algo que carece de avaliação. Achados recentes suportam a hipótese de que as alterações no metabolismo de RNA nos neurônios motores permitem a formação desses agregados protéicos na ELA (Strong, 2010; Droppelmann et al., 2013). De fato, estudos mostram a associação patológica da expansão na região não codificante do cromossomo 9 (C9ORF72) e a ELA (DejesusHernandez et al., 2011; Renton et al., 2011).

A questão da vulnerabilidade à morte seletiva dos neurônios motores na ELA é ainda desconhecida. Especula-se que o tamanho extenso dos prolongamentos dos neurônios motores implica em problemas relacionados ao transporte intracelular e ao metabolismo energético da célula, além da necessidade inerente dos suportes mitocontrial e citoesquelético adicionais, assim como a regulação da distribuição do RNA mensageiro para a síntese protéica (Ferraioulo et al., 2011). Ao contrário de outros grupos neuronais, 
esses neurônios têm níveis de expressão elevados dos canais de cálcio AMPA sem a subunidade GluR2 (Ince et al., 1993). Tal vulnerabilidade foi também recentemente relacionada ao aumento da expressão do receptor de Efrina A4 (Van Hoeke et al., 2012), à diminuição do receptor do fator de crescimento vascular endotelial (VEGF) (Brockington et al., 2006; Lunn et al., 2009), à alta sensibilidade ao estresse oxidativo (Saxena et al., 2009), além das alterações mitocondriais que acabam por aumentar o estresse oxidativo e os níveis de cálcio extracelular (Sullivan et al., 2004; Panov et al., 2011).

Defeitos no transporte axonal também são marcantes em diversas doenças neurodegenerativas (llieva et al., 2009). Camundongos SOD $1^{\mathrm{G} 93 \mathrm{~A}}$ apresentam diminuição no transporte axonal retrógrado (Perlson et al., 2009), mas também no anterógrado (Williamson e Cleveland, 1999). Isto diminui o suporte neuronal de ATP com consequente decréscimo na produção de dineínas e dinactinas (Tanaka et al., 2011), o que aumenta ainda mais a vulnerabilidade dessas células. Além disso, a expressão da subunidade p150 da dinactina-1 está diminuída nos neurônios motores de pacientes com ELA esporádica desde o início dos sintomas (Tanaka et al., 2011).

Defeitos mitocondriais também foram reportados na medula espinal (Sasaki e Iwata, 2007) e nas biópsias de músculos (Chung e Suh, 2002), fígado e córtex de pacientes com ELA (Menzies et al. 2002). Essas alterações, especialmente a presença de vacúolos com multimembranas, também foram observadas nos músculos e nos neurônios motores de camundongos SOD1 ${ }^{\mathrm{G} 37 R}$ e SOD $1^{\mathrm{G} 93 \mathrm{~A}}$ que acumulavam a SOD1m nos estágios precoces da doença, mais especificamente desde a $4^{\mathrm{a}}$ semana de vida, antes da ocorrência de qualquer perda neuronal (Gurney et al., 1994; Wong et al., 1995; Kong e Xu, 1998; Higgins et al., 2003; Martin et al. 2007).

Nesse sentido, a SOD1m parece interferir com os elementos das cadeias transportadoras de elétrons nas mitocôndrias dos neurônios, levando ao bloqueio da fosforilação oxidativa geradora de ATP (Mattiazzi et al., 2002; Browne et al., 2006). A SOD1m relaciona-se aos eventos pelos 
quais a mitocôndria tampona os níveis de $\mathrm{Ca}^{+2}$ citosólico, levando à falência de mecanismos anti-excitotóxicos (Petri et al., 2006). Agregados de SOD1m podem também interferir com os componentes da maquinaria apoptótica mitocondrial, ativando as cascatas apoptóticas nos neurônios pela liberação de citocromo C no citosol (llieva et al., 2009). A ativação da caspase-3 e a diminuição dos níveis da proteína anti-apoptótica Bcl-2 foram demonstradas nos neurônios motores espinais de pacientes com ELA (Ekegren et al., 1999). Ressalta-se que a combinação destes mecanismos pode ocorrer nas mitocôndrias não apenas dos neurônios, mas também das células gliais circundantes, resultando na degeneração neuronal através de diversos mecanismos nas várias fases de evolução da doença (Hensley et al., 2006). Experimentos de culturas de células mostraram a disfunção mitocondrial em células gliais e neuronais na presença da SOD1m (Ferri et al., 2006). A diminuição do transporte axonal na ELA, de fato, leva danos adicionais profundos à função mitocondrial (Martin et al., 2007), já que os neurônios motores SOD1 ${ }^{\text {G93A }}$ apresentam o acúmulo de mitocôndrias nos axônios terminais e geram níveis locais altos de radicais superóxidos comparados aos neurônios selvagens, evidências observadas tanto in vivo (Martin et al., 2007) quanto in vitro (De Vos et al., 2007). Trabalhos recentes mostram que esse acúmulo mitocondrial é de fato encontrado nas junções neuromusculares de camundongos SOD $1^{\mathrm{G} 93 \mathrm{~A}}$ juntamente com aumento de cálcio intracelular (Nguyen et al. 2009). Especula-se que, de fato, estas ocorrências colaboram para a manifestação da sintomatologia (Martin, 2011).

Notavelmente, a SOD1m também presente nas células não neuronais, principalmente nas células gliais, é decisiva para a evolução da doença. No sistema nervoso adulto, essas células atuam em diversos processos fisiológicos dos neurônios, por exemplo, na modulação da neurotransmissão, na produção de fatores neurotróficos, na regulação do desenvolvimento, na manutenção da vida da célula, bem como nos eventos de neuroplasticidade e envelhecimento neuronal (Neush et al., 2007). As 
células gliais participam também das respostas neuroimunomodulatórias e desempenham papel importante nos eventos neurodegenerativos de reparo e cicatrização (Morgenstern et al., 2002; Rhodes et al., 2003). O fato destas células contribuírem para as respostas inflamatórias agrega discussões acerca do seu papel dúbio, protetor/indutor, em doenças neurodegenerativas como no Parkinson, no Alzheimer e, sobretudo, na ELA (Philips e Robberecht, 2011). Pelo descrito acima, a desregulação dos mecanismos da interação neurônio-glia pode influenciar diretamente na integridade dos neurônios motores, contribuindo para a fisiopatologia da ELA. De fato, estudos recentes sugerem que, em determinadas situações, as células gliais podem contribuir para o dano neuronal na ELA por tornar o ambiente tóxico aos mesmos (Bruijn et al., 2004).

A construção de camundongos quiméricos com o promotor da SOD1m em tipos celulares específicos mostrou o aumento dos índices de morte neuronal e o fenótipo da doença no animal que possuía neurônios não mutantes envoltos por células gliais com a mutação, por outro lado, quando a expressão da mutação da SOD1 se apresentou apenas nos neurônios, as células gliais que o envolviam permaneceram relativamente intactas (Clement et al., 2003). Assim, o modelo de animal quimérico reforçou as especulações anteriores de que as células gliais podem estar envolvidas nos mecanismos da ELA.

Os astrócitos são as células mais abundantes no SNC (Zhang et al., 2010), participam da sinalização neurônio-glia nas sinapses e na manutenção da vida do neurônio pela secreção de substâncias solúveis (Haydon et al., 2001; Mazzanti et al., 2001; Zhang et al., 2005; Fellin et al., 2006; Haydon et al., 2006). A manutenção da concentração de glutamato extracelular em níveis fisiológicos pelo astrócito é especialmente relevante já que o glutamato em excesso na fenda leva à excitotoxicidade neuronal causada por influxo excessivo de cálcio. A retirada do excesso de glutamato da fenda sináptica por essas células é feita principalmente pelo transportador de glutamato EAAT2/GLT-1 (Bruijn et al., 1997). Pacientes 
com ELA familiar e esporádica bem como os camundongos com a SOD1m possuem expressão e imunorreatividade de EAAT2/GLT-1 diminuídas (Bruijn et al., 1997; Howland et al., 2002). Estes achados foram de grande impacto nos estudos da fisiopatologia da ELA e impulsionaram os experimentos com alvo terapêutico na doença, entretanto, análises subsequentes mostraram a alta complexidade dos possíveis mecanismos envolvidos, já que os astrócitos não são capazes de induzir a doença por si só, a despeito da expressão de SOD1m cursar com astrogliose na região do corno anterior da medula espinal (Gong et al., 2000). Interessantemente, Nagai et al. (2007) mostraram alterações na sobrevida de neurônios motores cultivados na presença de meio condicionado de astrócitos SOD1m, sendo que os neurônios SOD1m e aqueles não transgênicos eram igualmente afetados. De fato, trabalhos apontavam para 0 aumento da secreção do fator de crescimento do nervo (NGF) pelos astrócitos de pacientes com ELA e de camundongos com a SOD1m (Pehar et al., 2004; Turner et al., 2004; Ferraioulo et al., 2011) como possível causa da toxicidade. Adicionalmente, Yamanaka et al. (2008) sugeriram que a desregulação na interação entre as células gliais, em particular astrócito e microglia, pudessem ser um fator relevante na ELA, ao revelarem que a supressão de SOD1m nos astrócitos atrasou a ativação microglial.

A microglia representa 5 a $12 \%$ da população das células gliais e desempenha papel imunoefetor no SNC (Ling et al., 1973). De fato, quaisquer alterações na homeostase neuronal ativam a microglia (Streit et al., 1999). Em particular, a lesão do tecido nervoso induz a ativação microglial e a sua proliferação e subsequente secreção de citocinas, prostaglandinas e outras substâncias que participam do processo inflamatório (Kreutzberg et al., 1996; Hanisch et al., 2002). A ativação microglial está associada também ao aumento da produção de moléculas citotóxicas, como por exemplo, o óxido nítrico (NO), as proteases e as citocinas pró-inflamatórias como a interleucina-beta (IL-ß), o fator de necrose tumoral alfa (TNFa) e a interleucina 6 (IL-6). No estágio final da morte 
neuronal, a microglia ativada alcança o seu estágio fagocítico tornando-se grande e globosa (Streit et al., 1999).

A superativação da microglia foi observada em tecidos pós mortem de pacientes com ELA, indicando a presença de uma cascata de eventos pósinflamatória mediada por estas células durante 0 curso da neurodegeneração na doença (Kawamata et al., 1992). A microglia é encontrada em seu estado ativo no cérebro e na medula espinal não apenas de pacientes com ELA, mas também de camundongos e ratos que carregam a SOD1m (Henkel et al., 2004; Turner et al., 2004; Henkel et al., 2006), inclusive antes da fase da perda neuronal e do aparecimento da sintomatologia (Graber et al., 2010). Essa ativação microglial é descrita como uma ocorrência histológica precoce que ocorre cerca de 60 dias após o nascimento do animal transgênico (Troost et al., 1993; Alexianu et al., 2001; Weydt et al., 2003; Boillee et al., 2006). Outro estudo também demonstrou a presença de fatores solúveis pró-inflamatórios no fluído cérebro-espinal de pacientes com ELA muito possivelmente secretado pela microglia ativada (Almer et al., 2002). Nestes pacientes, a severidade da doença correlacionou-se à maior quantidade de fatores inflamatórios encontrados no líquido cefalorraquidiano (Keizman et al., 2009). Ainda, os níveis de receptores de TNF estavam elevados no soro destes indivíduos (Poloni et al., 2000).

A microglia é responsável pelo caráter progressivo de muitas doenças neurodegenerativas, principalmente pelo fato de desenvolverem uma relação modulatória complexa com os neurônios, exercendo papel tanto protetor quanto citotóxico a estas células (Henkel et al., 2009). As substâncias secretadas pela microglia em situações específicas e quando estas células se tornam reativas são apontadas como as principais responsáveis pela propagação da morte neuronal (Sargsyan et al., 2005; Neusch et al., 2007).

Inibidores da reatividade microglial são postulados como candidatos terapêuticos para ELA, pelo fato de diminuírem não só a secreção de 
glutamato, mas de outras moléculas formadoras da inflamação e morte neuronal (Beers et al., 2006). Sabe-se que a secreção de moléculas como superóxido, NO e TNFa pela microglia ativada aumenta a morte neuronal na ELA como demonstrado in vivo e in vitro (Akassoglou et al., 1997; He et al., 2002; Beers et al.,2006).

Outras evidências da participação da microglia na fisiopatologia da ELA foram obtidas com a constatação da exacerbação da sintomatologia nos camundongos SOD1m submetidos ao tratamento crônico com lipopolissacarídeo (LPS), substância esta classicamente utilizada como ativador microglial (Nguyen et al., 2004). De fato, a microglia SOD1m é mais responsiva ao estímulo do LPS do que a microglia proveniente de animais selvagens (Xiao et al., 2007). A microglia do animal SOD1m estimulada pelo LPS produz quantidades maiores de TNFa que aquelas produzidas pela respectiva célula do animal não transgênico (Weydt et al., 2004), abrindo a possibilidade desta citocina promover a toxicidade ao neurônio motor, efeito acompanhado pela diminuição da sobrevida do animal transgênico estimulado. A administração de antagonista do TNFa aumenta a sobrevida do animal SOD ${ }^{\text {G93A }}$ (West et al., 2004). A microglia SOD1m ativada libera quantidades maiores de $\mathrm{NO}$ e de superóxido que combinam-se para formar o peroxinitrato, composto altamente tóxico quando comparado ao observado na mesma célula do animal não transgênico (Beers et al. 2006). Esse mesmo estudo evidenciou que a substituição de microglias com a mutação por microglias selvagens prolonga a sobrevida do camundongo (Beers et al. 2006). Ainda, o co-cultivo de microglia SOD1m com neurônios motores provocou maior morte neuronal em comparação aos experimentos que utilizaram microglias selvagens, denotando o potencial neurotóxico maior das microglias transgências in vitro (Beers et al. 2006).

Por outro lado, a própria SOD1m liberada pelos neurônios e capaz de ativar a microglia vizinha, fechando assim um ciclo modulatório tóxico neurônio-microglia (Urushitani et al., 2006) com implicações no processo evolutivo da ELA. Estudo recente mostrou que a microgliose é ativada pela 
adição da SOD1 humana extracelular e ainda é atenuada quando a microglia é proveniente do animal mutante, resultando em maior morte neuronal do que situação em que a microglia proveniente do animal selvagem (Zhao et al., 2010).

Três estudos independentes mostraram que a microglia contribui para a propagação e a aceleração dos processos neurodegenerativos da ELA nas fases avançadas da doença. Porém, não é sabido ainda quais os mecanismos moleculares que regem tais eventos. A inibição da SOD1m microglial através da utilização do transgene $\mathrm{Cd} 11 \mathrm{~b}$-Cre promoveu atraso na progressão da doença no modelo SOD $1^{\mathrm{G} 37 \mathrm{R}}$. A sobrevida dos animais após o início dos sintomas aumentou quase 3 vezes comparado aos animais que não receberam o transgene (Boilee, 2006). Da mesma forma, a diminuição da progressão da ELA após a redução da expressão de SOD1m na microglia também foi confirmada na linhagem transgênica SOD $1^{\mathrm{G} 85 \mathrm{R}}$ (Wang et al., 2009).

Deste modo, dentre os mecanismos microgliais possíveis na ELA, a neuroinflamação mediada pela microglia transgênica ganha importância no desenvolvimento e na progressão da doença. Algumas revisões atuais respaldam este aspecto (Weydt et al., 2005; Papadimitriou et al., 2009). A ciclooxigenase-2 (COX-2), que é produzida por neurônios e astrócitos, mas em abundância pela microglia, estimula a produção local de citocinas próinflamatórias. A produção de COX-2 está aumentada na medula espinal de pacientes com ELA (Yiangou et al., 2006), o que reforça o envolvimento da microglia na patologia. De fato, a administração do celecoxibe, um inibidor da COX-2, na dose oral de 1500ppm em camundongos diariamente desde 0 $28^{\circ}$ dia de vida (Drachman et al., 2002), prolongou a sobrevida dos neurônios mutantes, interferindo no início da doença experimentalmente. Tal efeito não foi reproduzido em humanos com a dose correspondente utilizada nos camundongos de $800 \mathrm{mg} / \mathrm{dia}$ por via oral (Cudkowicz et al., 2006). A administração de outras drogas anti-inflamatórias nas fases finais da doença em camundongos com ELA também prolonga a sobrevida do animal 
(Klivenyi et al., 2004; Lorenzl et al., 2006), porém não mostram efeitos clínicos importantes (Appel et al., 1988; Werdelin et al., 1990; Gordon et al., 2007; Stommel et al., 2009).

A minociclina, um derivado de tetraciclina capaz de inibir a ativação microglial, também aumentou a sobrevida do camundongo modelo da ELA (Kriz et al., 2002). Por outro lado, estudos clínicos envolvendo a administração deste composto em pacientes com ELA também não mostrou resultados positivos (Gordon et al., 2007). A principal hipótese para a falta de resultados clínicos parece ser a impossibilidade do diagnóstico pré-clínico e assim, talvez, a ativação microglial já deve ser resistente às intervenções farmacológicas (Keller et al., 2010).

As ações da microglia podem ser outras que não apenas a promoção da inflamação, esta de fato pode vir como consequência. Trabalhos recentes têm mudado o foco da citotoxicidade da microglia na ELA. Qualquer alteração fisiológica no microambiente induz a migração dessas células até o sítio de lesão, algo que ocorre rapidamente para realização de suas ações. A integrina, uma proteína de adesão, parece ser responsável pela propriedade dinâmica da microglia (Sargsyan et al., 2011). Surpreendentemente, Sargsyan et al. (2011) revelaram que a microglia SOD1 ${ }^{\text {G93A }}$ possui deficiências nas características neuroprotetoras quando comparadas com as células microgliais de animais selvagens, principalmente no que diz respeito à sua capacidade migratória. Ainda, a expressão baixa de integrina na microglia SOD1m e a habilidade reduzida de sua locomoção ao sítio de lesão foram constatadas (Sargsyan et al., 2011). Dessa forma, esses achados indicam que a microglia SOD1m pode precisar de concentração maior de fatores estimulantes para ter uma resposta igual àquela obtida por uma célula microglial não mutante.

O estudo de Dibaj et al. (2011) também se destacou ao mostrar que a microglia $S O D 1^{\mathrm{G} 93 \mathrm{~A}}$ de animais submetidos a lesão axonal apresenta resposta microglial diferente dependendo da idade do animal. Animais 
submetidos a esta lesão na fase pré-clínica da doença, com 60 dias de idade, tiveram uma reação microglial semelhante aos animais controles, porém a resposta microglial foi diminuída no animal mais velho, já sintomático com 120 dias, evidenciando uma possível perda de função microglial nas idades sintomáticas.

Com as evidências descritas acima, o papel exato da microglia na fisiopatologia da ELA ainda é desconhecido. $O$ fato de não existir tratamento capaz de ao menos atrasar o início dos sintomas da doença estimulou a proposta do presente trabalho que busca estudar as alterações moleculares e a influência microglial na sobrevida do neurônio motor. As microglias foram extraídas de camundongos $\mathrm{SOD} 1^{\mathrm{G} 93 \mathrm{~A}}$ logo após o nascimento e pouco antes do início dos sintomas (1 e 60 dias) com o intuito de indicar algum marcador precoce para o desenvolvimento de futuras terapias. 


\section{Objetivos}

\subsection{Geral}

Avaliar a natureza celular e molecular da influência microglial na morte do neurônio motor em sistemas de co-culturas neurônio motor/microglia obtidos da medula espinal dos camundongos transgênicos SOD1 ${ }^{\text {G93A }}$ (TG) e não transgênicos (wild type, WT). Neste contexto, estudar a ocorrência de efeitos diferenciais da microglia obtida do tecido de animal neonato com 1 dia de vida (P1) e adulto jovem na fase pré-sintomática com 60 dias de idade (P60).

\subsection{Objetivos específicos}

2.2.1. Adequar a metodologia para a obtenção de culturas de neurônios motores da medula espinal de camundongos controles (WT) e transgênicos SOD1 ${ }^{\text {G93A }}$ (TG) em P1.

2.2.2. Avaliar a influência da microglia de animais $W T$ e TG na viabilidade dos neurônios motores utilizando métodos estereológicos específicos de contagem de células em sistemas de co-cultura neurônio/microglia.

2.2.3. Avaliar a influência do meio condicionado obtido das culturas de microglia de animais WT e TG no estado trófico dos neurônios motores espinais de animais WT e TG através da quantificação do número e dos prolongamentos neuronais bem como a viabilidade destes neurônios, utilizando métodos estereológicos específicos de contagem de células.

2.2.4. Quantificar a expressão de moléculas candidatas à participar do processo neurodegenerativo nos meios condicionados das culturas microgliais por ELISA. 
2.2.5. Quantificar a expressão gênica de moléculas potencialmente envolvidas no desenvolvimento da doença nas microglias WT e TG cultivadas de ambas idades através da técnica do PCR em tempo real. 


\section{Materiais e Métodos}

Este estudo foi aprovado pela Comissão de Ética e de Biossegurança em Organismos Geneticamente Modificados da Faculdade de Medicina/Hospital das Clínicas da Universidade de São Paulo (Aprovação número: 0113/08).

\subsection{Modelo animal da ELA}

Camundongos transgênicos B6SJL-TgN(SOD1 $\left.{ }^{\mathrm{G} 93 \mathrm{~A}}\right) 1$ Gur que expressam o gene mutante SOD ${ }^{\mathrm{G} 93 \mathrm{~A}}$ humano, originalmente produzidos por Gurney et al. (1994), foram obtidos do Laboratório Jackson (Bar Harbor, ME, USA). Estes animais são amplamente utilizados como modelo experimental para o estudo da ELA (Miana-Mena et al., 2005).

\subsubsection{Colônias de animais}

Colônias de animais transgênicos (SOD1 ${ }^{\mathrm{G} 93 \mathrm{~A}}$, TG) e controles (B6SJL) foram estabelecidas no Biotério Central da Faculdade de Medicina da Universidade de São Paulo. A reprodução e o alojamento dos animais foram feitos em ambiente desprovido de patógenos específicos (spf) para garantir a estabilidade das colônias, controle sobre a reprodução e homogeneidade fenotípica entre os animais. Esta parte dos experimentos foi feita por técnicos especializados do Biotério Central da Faculdade de Medicina da Universidade de São Paulo. O regime spf compreende gaiolas ventiladas e com filtros especiais, bem como a manipulação dos camundongos e suas proles em regime estéril dentro de câmara de fluxo laminar. Temperatura ambiente controlada entre 21 e $22^{\circ} \mathrm{C}$, umidade do ar em torno de $55 \%$ e iluminação sob ciclo claro/escuro de 24 horas, sendo cada fase do ciclo de 12 horas, foram itens que receberam também a atenção. A ração, a água e a maravalha foram rotineiramente autoclavadas antes da utilização. Como controle da não contaminação da colônia por agentes patogênicos, os animais foram periodicamente submetidos a controles bacteriológico e 
parasitológico segundo a rotina spf estabelecida no Biotério da Faculdade de Medicina da Universidade de São Paulo. Os cruzamentos foram realizados entre machos heterozigotos SOD $1^{\mathrm{G} 93 \mathrm{~A}}$ com fêmeas da linhagem B6/SJL-F1, com o intuito de gerar uma prole aproximadamente $50 \%$ heterozigota TG e $50 \%$ WT, segundo orientações do Laboratório Jackson que forneceu as matrizes para o início das colônias. Esse desenho de amplificação das colônias permitiu as melhores condições controle e experimentais.

Os casais foram mantidos com suas respectivas proles até 30 dias de idade quando, então, foram separados por sexo e pelo genótipo. Os animais transgênicos são utilizados como experimentais e os não transgênicos como controles.

\subsubsection{Genotipagem dos camundongos}

A identificação dos camundongos TG ou WT utilizados nos experimentos foi realizada através da genotipagem. $O$ primeiro passo constituiu na extração de amostras de DNA de cada um dos animais a partir de fragmento da cauda.

O procedimento de extração de DNA seguiu o protocolo a seguir: $500 \mu \mathrm{l}$ de tampão contendo $1 \mathrm{mg} / \mathrm{ml}$ de proteinase $\mathrm{K}, 20 \mathrm{mM}$ Tris- $\mathrm{HCl}(\mathrm{pH} 8,0)$, $10 \mathrm{mM} \mathrm{NaCl}, 30 \mathrm{mM}$ EDTA (pH8,0) e 0,5\% SDS (Sigma) que foram adicionados a cada tubo contendo as amostras individuais. Cada amostra foi homogeneizada e incubada a $60^{\circ} \mathrm{C}$ sob agitação de $1400 \mathrm{rpm}$ no Thermomixer (Eppendorf) por uma hora, seguida de centrifugação a $16000 \mathrm{~g}$ por 10 minutos. O sobrenadante destas amostras foi transferido de tubo contendo $500 \mu \mathrm{l}$ de isopropanol gelado e misturado suavemente até o aparecimento de precipitado. As amostras foram centrifugadas a 14000rpm por 10 minutos à $4^{\circ} \mathrm{C}$ e os sobrenadantes desprezados. Os tubos foram lavados a seguir com $500 \mu \mathrm{l}$ de etanol $70 \%$ e uma segunda vez com $500 \mu \mathrm{l}$ da mesma solução. Após uma centrifugação final de 14000rpm por 5 minutos, os sobrenadantes foram descartados e os tubos deixados para secar em posição invertida. Após a secagem do precipitadode DNA, cada amostra foi 


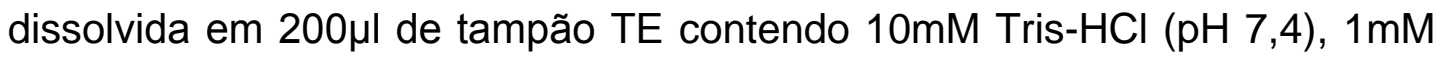
EDTA e água deionizada. As amostras de DNA foram armazenadas à $4^{\circ} \mathrm{C}$ até a realização da genotipagem por Reação em Cadeia da Polimerase (PCR).

Os iniciadores utilizados que permitiram a realização da genotipagem através da técnica de PCR foram IMR113 (5'-ATCAGCCCTAATCCATCTGA3') e IMR114 (5'-16 CGCGACTAACAATCAAAGTGA-3') para amplificação de um fragmento da SOD1humana e IMR042 (5'-CTAGGCCACAGAA TTGAAAGATCT-3') e IMR043 (5'-GTAGGTGGAAATTCTAGCATCATCC-3') para amplificação de um fragmento da interleucina-2 (IL-2) de murino como controle positivo (Rosen et al., 1993). Estes iniciadores estão descritos no protocolo do Laboratório Jackson (http://jaxmice.jax.org/pubcgi/protocols/protocols.sh?objtype=protocol\&protoc ol_id=523). A reação de PCR incluiupara cada amostra 12,5 $\mu$ I PCR Master Mix (2X) (Fermentas Life Sciences), 500nM de cada iniciador supracitado, 100 ng de DNA e água livre de nucleotídeos para o volume final de $25 \mu \mathrm{l}$. A reação compreendeu um período inicial de 3 minutos à $95^{\circ} \mathrm{C}$, seguidos por 35 ciclos de $95^{\circ} \mathrm{C}$ por 30 segundos, $60^{\circ} \mathrm{C}$ por 30 segundos e $72^{\circ} \mathrm{C}$ por 45 segundos, que se repetiam por 35 ciclos, além do período de 2 minutos à $72^{\circ} \mathrm{C}$ com resfriamento até $10^{\circ} \mathrm{C}$.

Os produtos das reações dos PCRs foram visualizados sob luz ultravioleta após eletroforese em gel de agarose 1\% com brometo de etídeo e fotografados para documentação (Figura 1). 


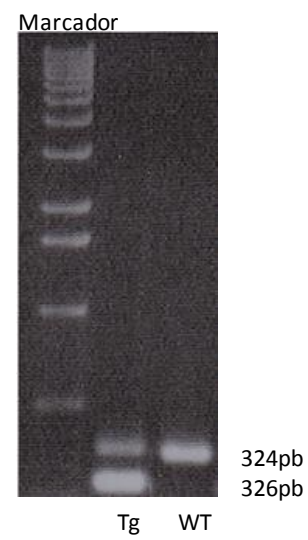

Figura 1. Imagem de gel de agarose visualizado sob luz ultravioleta. As amostras foram obtidas a partir da cauda e subsequente genotipagem por PCR utilizando-se sondas para amplificação de um fragmento da interleucina-2 (IL-2) de murino como controle positivo e da SOD1 mutante. Para o animal transgênico $(\mathrm{Tg})$ observa-se a presença da forma mutante da SOD1 (com 326 pares de bases) e da IL-2 (com 324 pares de bases). Já nos animais controles wild-type (WT) observa-se apenas a presença da IL-2.

\subsection{Culturas primárias de células}

Culturas primárias de neurônios motores e microglia foram obtidas das medulas espinais de camundongos WT e TG com 1 dia de vida pósnatal (P1) segundo protocolos publicados e previamente modificados em nosso laboratório. Além disso, a cultura de microglia também foi obtida a partir da medula espinal de animais adultos jovens dos mesmos genótipos com 60 dias de idade (P60), período em que a microglia já se encontra ativada, na fase que precede os primeiros sintomas clínicos clássicos da doença (Troost el al., 1993; Hall et al., 1998; Alexianu et al., 2001; Weydt et al., 2003; Alves et al., 2011).

A grande maioria dos estudos em ELA utiliza culturas de neurônios a partir da medula espinal de animais em idades embrionárias devido à dificuldade de obtenção destas células após o nascimentodo animal, entretanto o nosso laboratório conseguiu bons resultados com a obtenção destas células do animal P1, após adaptação do protocolo (Scorisa et al., 2010). Os animais neonatos foram decapitados no seu primeiro dia de vida pós-natal e imersos em solução de etanol 70\% por cerca de 2 minutos para assepsia da superfície corpórea. A região lombar da medula espinal foi exposta e removida com tesouras previamente esterilizadas. Posteriormente, 
a dura-máter e vasos sanguíneos foram retirados da medula espinal, com o auxílio de duas pinças microcirúrgicas sem danificar o tecido, que era, então, colocado em placa de vidro de $60 \mathrm{~mm}$ esterilizada e submetido aos protocolos descritos a seguir.

\subsubsection{Cultura de neurônios motores}

A cultura de neurônios motores da medula espinal foi realizada a partir do protocolo descrito por Henderson et al., (2002) adaptado pelo pesquisador Bradley Turner da Universidade de Melborne (Austrália) e gentilmente cedido para nós. Ainda assim, foram realizadas algumas modificações e adequações no protocolo que possibilitou a realização do cultivo dessas células obtidas a partir de medula espinal de animais WT e TG P1.

A medula espinal dissecada foi colocada em solução tampão fosfato (PBS). Em seguida, o tecido foi transferido para um novo tubo contendo PBS e tripsina na concentração final de 0,025\% (Gibco) e levado para banhomaria à $37^{\circ} \mathrm{C}$ por 5 minutos seguidos de 5 minutos sob leve agitação. Após o período em banho-maria, o tecido foi imediatamente colocado em um novo

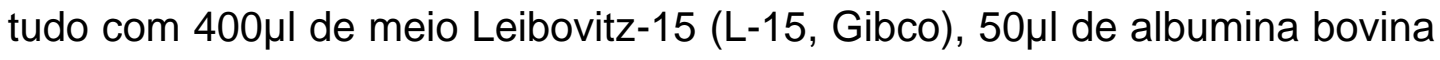

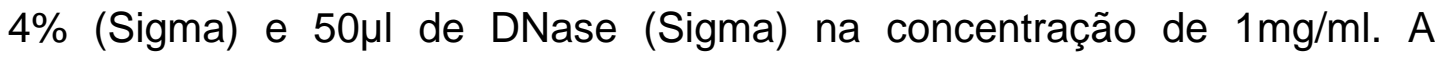
solução foi então agitada vigorosamente até que o tecido se fragmentasse. Em seguida, a solução foi dissociada com a pipeta por duas vezes e os fragmentos foram assentados e transferidos de tubo, no qual foi adicionado $450 \mu \mathrm{l}$ de $\mathrm{L}-15,50 \mu \mathrm{l}$ de albumina bovina $4 \%$ e $10 \mu \mathrm{l}$ de DNase na concentração de $1 \mathrm{mg} / \mathrm{ml}$. Os fragmentos foram ressuspendidos e diluídos. No tubo com os fragmentos diluídos foi adicionado o sobrenadante do tubo anterior, quando $1 \mathrm{ml}$ de albumina bovina $4 \%$ foi cuidadosamente aplicado com uma pipeta Pasteur no centro do fundo do tubo. O mesmo foi submetido à centrifugação de 5 minutos à $350 \mathrm{~g}$. Após, o sobrenadante foi descartado $\mathrm{e}$ o precipitado ressuspendido em $1 \mathrm{ml}$ de $L-15$. As células foram completamente dissociadas e transferidas cautelosamente para um novo 
tubo já contendo $1 \mathrm{ml}$ de $3,7 \%$ de gradiente de densidade Optiprep (Sigma) diluído em tricina, no qual então era visível a região densa e não translúcida de interface. O tubo foi levado para centrifugação a $700 \mathrm{~g}$ por 15 minutos sem breque, para separar as células de acordo com sua densidade. Após a centrifugação, uma banda turva na interface representava os neurônios motores. Essa banda foi cuidadosamente coletada e os mesmos foram contados e plaqueados em placa com 24 poços com lamínula de vidro, previamente tratada com Poli-L-D-Ornitina $(25 \mu \mathrm{g} / \mathrm{ml}$; Sigma) e laminina $(25 \mu \mathrm{g} / \mathrm{ml}$; Sigma) por duas horas cada um. Cada medula espinal fornecia cerca de $10^{5}$ células, que por sua vez eram cultivadas com meio neuronal que consistia em uma solução de meio Neurobasal A suplementado com 1\% de penicilina/estreptomicina, $2 \%$ de soro de cavalo, $0,5 \mathrm{mM}$ de L-glutamina, $25 \mu \mathrm{M}$ de 2-mercaptoethanol, $10 \mathrm{ng} / \mathrm{ml}$ de fator neurotrófico ciliar (CNTF), $100 \mathrm{pg} / \mathrm{ml}$ de fator neurotrófico derivado da glia (GDNF) todos adquiridos da Sigma e suplemento B-27 da Gibco.

As placas de culturas contendo os neurônios derivados dos animais WT e TG foram acompanhadas por 6 dias após o plaqueamento. As culturas foram avaliadas para determinação da pureza e submetidas ao tratamento do meio condicionado microglial descrito a seguir.

\subsubsection{Cultura de microglia obtida a partir de camundongo neonato em P1}

As medulas espinais foram obtidas conforme descrito acima e a obtenção de culturas de microglia dos camundongos WT e TG em P1 foram obtidas a partir de uma cultura mista de células gliais conforme descrito na literatura (Giulian e Baker, 1986). Para isso, as medulas espinais desses animais foram retiradas e submetidas à digestão com $0,25 \%$ de tripsina (Gibco) por 30 minutos à $37^{\circ} \mathrm{C}$. A ação da tripsina foi interrompida adicionando-se o mesmo volume de meio de cultura (DMEM, Gibco), 10\% de soro fetal bovino (SFB, Gibco), penicilina e estreptomicina 100u/mL- D10, 
no qual $0,02 \%$ de DNase foi adicionado. Em seguida o conteúdo foi centrifugado por 5 minutos à $200 \mathrm{~g}$ e ressuspendido em meio de cultura. $\mathrm{O}$ tecido foi então triturado através de múltiplas pipetagens com pipeta Pasteur seguida de dissociação através de uma agulha 20G. As células foram plaqueadas em placas de 6 poços e mantidas à $37^{\circ} \mathrm{C}$ em incubadora de $\mathrm{CO}_{2}$ à $5 \%$. $O$ meio de cultura foi trocado a cada 2 dias. A cultura atingia a confluência perto do décimo dia, contendo cerca de $75 \%$ de astrócitos e $25 \%$ de microglia.

A cultura de microglia foi preparada através de suaves tripsinizações, (Saura et al., 2003). Deste modo, a cultura glial confluente por no mínimo 3 dias foi lavada por cerca de 1 minuto com DMEM para eliminação do soro e tripsinizada com uma solução de tripsina $(0,06 \%)$ na presença de EDTA

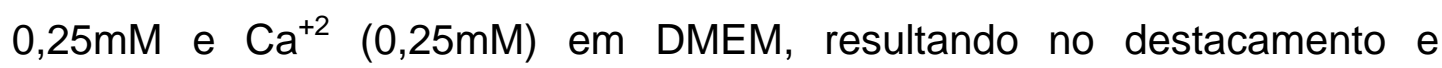
eliminação dos astrócitos que compunham $75 \%$ da placa naquele momento, deixando, então, a microglia intacta. Nessa etapa, as microglias cultivadas foram utilizadas para a determinação da pureza, ou então destacadas e plaqueadas sob os neurônios motores formando o sistema de co-cultura, ou replaqueadas na densidade de $2,5 \times 10^{4}$ para sua ativação com LPS (Sigma) e condicionamento do meio, procedimentos que serão descritos abaixo.

\subsubsection{Cultura de microglia obtida a partir do camundongo adulto pré- sintomático em P60}

Os procedimentos para a cultura de microglia a partir da medula espinal adulta foram reproduzidos conforme descrito por Marriot et al. (1996) e modificado em nosso laboratório. Cada animal assintomático em P60, WT e TG, foi perfundidos com solução salina por 3 minutos para eliminar qualquer célula sanguínea das suas medulas espinais. Antes da perfusão, $10 \mu \mathrm{l}$ de heparina foram adicionados ao coração para auxiliar a completa eliminação de células do sangue (Moussaud e Draheim, 2010). Em seguida, as medulas espinais foram removidas e suas meninges e vasos sanguíneos retirados com auxílio de pinças finas previamente esterilizadas. $\mathrm{O}$ tecido foi 
então colocado em uma solução salina balanceada de Earle (Earle's balanced salt solution; Sigma) e levada ao fluxo laminar, onde a solução foi trocada por uma nova e os fragmentos medulares foram cortados com o auxílio de uma tesoura. Tais fragmentos foram dissociados com uma seringa acoplada à agulha de 19G. Quando as medulas espinais estavam completamente dissolvidas na solução, foram então centrifugadas a $700 \mathrm{~g}$ por 5 minutos. O sobrenadante foi descartado e o precipitado ressupendido em DMEM suplementado com $0,1 \mathrm{mg} / \mathrm{ml}$ de I-valina, $10 \%$ SFB e $100 \mathrm{u} / \mathrm{ml}$ de penicilina e estreptomicina. As células foram plaqueadas em placas de 6 poços previamente tratados com Poli-L-Lisina (PLL; Sigma) e mantidas à $37^{\circ} \mathrm{C}$ em incubadora de $\mathrm{CO}_{2}$ à $5 \%$. Aproximandamente 4 semanas após, a cultura glial atingia a confluência.

Três dias após atingirem esta fase, os astrócitos foram eliminados como descrito acima no protocolo da microglia neonatal, através de suaves tripsinizações (Saura et al., 2003). Depois de purificadas, as culturas de microglia foram destacadas e plaqueadas sob os neurônios motores formando o sistema de co-cultura ou, então, replaqueadas na densidade de $2,5 \times 10^{4}$ para sua ativação com LPS e condicionamento do meio.

\subsection{Determinação da pureza das culturas primárias}

\subsubsection{Imunoperoxidase e imunofluorescência}

Para a verificação da pureza das culturas primárias, as células cultivadas foram submetidas a marcações pela imunoperoxidase ou imunofluorescência ( $n=3$ ) (Duobles et al., 2008). Para isso, as culturas de células foram purificadas sob lamínulas e no dia seguinte, lavadas duas vezes com tampão fosfato (PBS) e fixadas com paraformaldeído $4 \%$ gelado por 1hora. Em seguida, as células foram lavadas novamente com PBS e permeabilizadas através de solução de PBS com 1\% Triton (Sigma) por 10 minutos. A permeabilização foi concluída após lavagem das células com 0,02\% Tween 20 (BioRad) em PBS por 5 minutos e 0,02\% Tween 20 e 1\% albumina bovina por 5 minutos. O bloqueio foi realizado com solução de PBS 
com $2 \%$ de soro de cabra (Sigma), 4\% BSA, 0,2\% Triton por 30 minutos. Para verificar a pureza das culturas microgliais, foi realizada uma incubação com o anticorpo policlonal contra $\mathrm{Cd11b}$ (BD Biosciences) na concentração 1:600 em solução com $2 \%$ de soro de cabra, $4 \%$ BSA, $0,2 \%$ Triton em PBS por 18 horas em geladeira $\left(4^{\circ} \mathrm{C}\right)$. No dia seguinte, as lamínulas foram lavadas 3 vezes em PBS e em seguida realizou-se a incubação do anticorpo secundário anti-coelho ( $\operatorname{lgG}$ ) biotinilado (Vector) na diluição 1:250 e na mesma solução que o anticorpo primário. Novamente, as culturas foram lavadas em PBS e incubadas com avidina-biotina para amplificação do sinal da imunocitoquímica. A reação foi feita com DAB (Sigma) a $0,5 \mathrm{mg} / \mathrm{ml}$ e $0,01 \% \mathrm{H}_{2} \mathrm{O}_{2}$ até a coloração marrom ser observada. Após interrupçãoda reação com trizma, as culturas foram lavadas em PBS por diversas vezes e o bloqueio era repetido por mais 10 minutos. Em seguida, o anticorpo contrao marcador de astrócito, Proteína Glial Fibrilar Ácida (GFAP, Sigma), foi incubado na concentração 1:200 por 48 horas e as incubações do anticorpo secundário e avidina e biotina foram feitas da mesma maneira que a descrita acima. A reação do GFAP foi realizada em 4-cloro-naftol para observação da coloração em azul, obtendo uma dupla marcação (Duobles et al., 2008; Scorisa et al., 2010).

As culturas neuronais foram submetidas ao mesmo processo, porém o anticorpo primário contra a colina acetil transferase (ChAT, Millipore), específico para neurônio motor, foi incubado na mesma solução por 48 horas na concentração de 1:1500. O procedimento de lavagem se repetiu da mesma forma àquela descrita acima, porém o anticorpo secundário utilizado foi produzido em cabra e conjugado ao vermelho do Texas (Vector). Tais lamínulas foram montadas com Montex acoplado ao marcador nuclear DAPI (Vector) e analisadas em microscópio de fluorescência.

As lamínulas com culturas microgliais e neuronais foram montadas e as imagens foram analisadas em microscópio de fluorescência. Fotografias foram feitas para quantificações da pureza da cultura, descrita mais a frente. 


\subsubsection{PCR semi-quantitativo}

Para realização das PCRs semi-quantitativas, o RNA das células foi extraído pelo método de Trizol (Sigma) de acordo com as recomendações do fabricante. Resumidamente, foi adicionado trizol aos poços de cultura, a solução foi coletada e centrifugada e em seguida $200 \mu$ l de clorofórmio foram adicionados e então a solução foi agitada vigorosamente e mantida por 5 minutos em temperatura ambiente. As fases foram separadas por centrifugação $12000 \mathrm{~g}$ por 15 minutos à $4^{\circ} \mathrm{C}$. A fase aquosa, que continha 0 RNA, foi transferida para outro tubo ao qual foi adicionado $500 \mu \mathrm{l}$ de isopropanol. Após homogeneização, a solução foi incubada à $-80^{\circ} \mathrm{C}$ durante 18 horas para melhorar a eficiência da precipitação pelo isopropanol. Em seguida, as amostras foram deixadas descongelar sobre gelo e então foram descansadas à temperatura ambiente durante 10 minutos, seguidos de centrifugação a $13000 \mathrm{~g}$ por 10 minutos à $4^{\circ} \mathrm{C}$ para coleta do RNA. O precipitado foi lavado por duas vezes com etanol $75 \%$ e centrifugado a $1500 \mathrm{~g}$ por 5 minutos à $4^{\circ} \mathrm{C}$. Após a remoção do etanol, o RNA foi eluído em $20 \mu l$ de água livre de nucleotídeos. Para transformar o RNA em DNA complementar (cDNA) foi utilizado $1 \mu \mathrm{g}$ do RNA total extraído com $2 \mu \mathrm{l}$ de água livre de nucleotídeos e o Lit Ready-to-go PCR beads (GE healthcare), de acordo com as recomendações do fabricante, seguido de 40 ciclos de amplificação. Em seguida, o cDNA, produto de PCR transcriptase reversa, foi amplificado com os iniciadores específicos obtidos do GenBank para o GFAP (5'-GCA GAG ATG ATG GAG CTC AAT GAC C-3' e 3'-GTT TCA TCC TGG AGC TTC TGC CTC A-5'), O Cd11b (5'- ATG GAC GCT GAT GGC AAT ACC-3' e 3'-TCC CCA TTC ACG TCT CCA- 5') e o GAPDH (5'- CCA AGG TCA TCC ATG ACA AC-3' e 3' GCT TCA CCA CCT TCT TGA TG-5') por PCR simples. O produto dessas PCRs foi pipetado em gel de agarose $1 \%$ com brometo de etídio para observação sob luz ultravioleta. 


\subsection{Estabelecimento da co-cultura neurônio/microglia}

Células neuronais dos animais WT e TG foram cultivadas como descrito acima. No dia seguinte da cultura, as microglias cultivadas de animais WT e TG em idades P1 e P60 foram tripsinizadas com tripsina $0,25 \%$ (Sigma), centrifugadas e plaqueadas à densidade de $2,5 \times 10^{4}$ sob os neurônios em meio neuronal trocado previamente o que possibilitou os sistemas de co-cultura. Diferentes combinações de co-cultura foram realizadas, como descrito abaixo, para a análise da influência da microglia WT ou TG na morte de neurônio WT ou TG.

\subsection{Ativação microglial com LPS e avaliação de seu estado ativo}

Seis culturas purificadas de microglia provenientes de animais WT e TG em idades $\mathrm{P} 1$ e $\mathrm{P} 60$ foram tripsinizadas e transferidas para uma placa de 96 poços na concentração de $2,5 \times 10^{4}$ células/poço, para que as moléculas secretadas no meio ficassem suficientemente concentradas para facilitar a

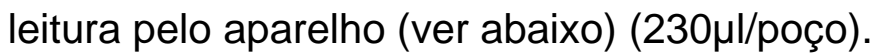

Tais culturas foram ativadas com LPS em duas concentrações diferentes 1 e $10 \mu \mathrm{M}$ com intuito de avaliar seu estado ativo (Weydt et al., 2004; Xiao et al., 2007). Os meios das amostras foram coletados 48 horas após e centrifugados $(700 \mathrm{~g}$ por $10 \mathrm{~min}$ ) para eliminar as células em suspensão, congelados em alíquotas de $100 \mu \mathrm{l}$ e $200 \mu \mathrm{l}$ e armazenados à $-80^{\circ} \mathrm{C}$

Os sobrenadantes foram submetidos à técnica do reagente de Griess (Promega) para a determinação da quantidade secretada de NO (Ignarro et al., 1987). Essa quantidade está diretamente relacionada ao grau de ativação microglial (Block et al., 2005). Para tal, as amostras foram descongeladas e $50 \mu \mathrm{l}$ de cada uma foram incubados com $50 \mu \mathrm{l}$ do reagente de Griess por 20 minutos à temperatura ambiente. Cada alíquota de $100 \mu l$ foi utilizada em duplicata, representando uma amostra. A reação 
colormétrica é explicada resumidamente a seguir. $\mathrm{O}$ reagente de Griess contém ácido sulfanílico e $\mathrm{N}$-etilenodiamina, sendo que o ácido sulfanílico é quantitativamente convertido em sal de diazônio pela reação do nitrito em uma solução ácida. Esse sal, por sua vez, se liga ao N-etilenodiamina, formando um corante que é quantificado no espectrofotômetro na absorbância de 548nm (Ignarro et al., 1987; Tracey et al., 1990). Curva de diluições seriadas com concetrações conhecidas de nitrito foi feita para quantificação comparativa.

\subsection{Análise do estado trófico do neurônio na presença do meio condicionado de microglia}

Após 4 dias em cultura na placa de 6 poços, $1 \mathrm{ml}$ de meio condicionado da cultura de microglia foi coletado e centrifugado ( $700 \mathrm{~g}$ por 5 minutos) para eliminar as células em suspensão. O sobrenadante foi coletado e congelado como descrito acima. Para a análise do estado trófico do neuônio, os meios condicionados microgliais foram utilizados no tratamento neuronal. Antes do uso, os meios condicionados foram suplementados com penicilina/estreptomicina e coquetel de fatores neurotróficos (Nagai et al., 2007).

Esse tratamento foi realizado com e sem ativação com LPS. Para aqueles meios nos quais as microglias foram submetidas à ativação com LPS na placa de 96 poços, 2 dias após a ativação, cerca de $200 \mu \mathrm{l}$ de meio condicionado foi coletado e processado como descrito logo acima.

Os experimentos com meio condicionado foram conduzidos segundo o protocolo estabelecido no nosso laboratório. Neurônios foram obtidos de animais WT e TG como descrito acima. As células foram fotografadas sob microscópio invertido já antes do tratamento com meio microglial para quantificação de seus corpos celulares e prolongamentos. Ao final do $1^{\circ}$ dia de cultura, vinte por cento do meio de cultivo neuronal foi substituído pelo meio condicionado das culturas de microglia obtida de animais WT e TG, de 
ambas as idades. Os procedimentos de tratamento foram repetidos do $1^{\circ}$ ao 6 o dia de cultura e o procedimento de documentação das imagens foi feito no $5^{\circ}(\mathrm{n}=3)$ dia de tratamento.

Quadro do resumo dos tratamentos das culturas de neurônios com os meios condicionados microgliais é apresentado a seguir:

\begin{tabular}{|c|c|}
\hline Neurônio & $\begin{array}{c}\text { Meio condicionado } \\
\text { microglial/ idade }\end{array}$ \\
\hline WT & WT P1 $(n=3)$ \\
& TG P1 $(n=3)$ \\
& WT P60 $(n=3)$ \\
& TG P60 $(n=3)$ \\
\hline TG & WT P1 $(n=3)$ \\
& TG P1 $(n=3)$ \\
& WT P60 $(n=3)$ \\
& TG P60 $(n=3)$ \\
\hline
\end{tabular}

\subsection{Análise da morte neuronal em co-culturas neurônio/microglia}

Para a análise da influência da microglia WT ou TG de ambas as idades em co-cultura com neurônios WT ou TG, os sistemas foram formados da seguinte forma:

\begin{tabular}{|c|c|}
\hline Neurônio & Co-cultura microglia/ idade \\
\hline WT & WT P1 $(n=3)$ \\
& TG P1 $(n=3)$ \\
& WT P60 $(n=3)$ \\
& TG P60 $(n=3)$ \\
\hline TG & WT P1 $(n=3)$ \\
& TG P1 $(n=3)$ \\
& WT P60 $(n=3)$ \\
& TG P60 $(n=3)$ \\
\hline
\end{tabular}


Para a quantificação da morte neuronal nas co-culturas, estas foram submetidas à marcação com FluoroJade $\mathrm{C}$, conforme descrito a seguir, e visualizadas/fotografadas em microscópio de fluorescência. Após marcação, 6 campos fotográficos de cada poço foram rapidamente obtidos e o número de corpos de neurônios motores em degeneração foram quantificados.

\subsection{Presença de marcador de degeneração neuronal}

\subsubsection{Presença de marcador de degeneração neuronal nos neurônios submetidos a tratamento com meio condicionado microglial}

Culturas de neurônios WT e TG que foram tratadas com meio condicionado microglial de ambas as linhagens foraminterrompidas no $5^{\circ}$ dia de tratamento e submetidas à marcação de FluoroJade $C$ (Millipore) ( $n=3$ para cada linhagem de meio condicionado). Para isso, as culturas foram lavadas 2 vezes com PBS e fixadas com paraformaldeído a 4\% por 1 hora. Em seguida, o fixador foi retirado e resíduos dele foram removidos com uma lavagem em água destilada. As células foram permeabilizadas com uma solução de triton $0,3 \%$ em água destilada por 10 minutos e lavadas novamente em água. $\mathrm{O}$ marcador de morte neuronal, FluoroJade $\mathrm{C}$, foi incubado à $0,0001 \%$ no escuro, por 30 minutos, o que proporcionou a visualização dos neurônios em degeneração em verde. Após a marcação, as lamínulas foram montadas com MONTEX contendo DAPI (Vector) para observação dos núcleos em azul. Uma vez que a cultura foi comprovadamente considerada pura para neurônios, todas as células marcadas pelo FluoroJade $\mathrm{C}$ foram consideradas em processo de morte, por outro lado, células cujos núcleos estivessem intactos foram consideradas saudáveis. As lâminas foram observadas em microscópio de fluorescência (Olympus AX70) e quantificadas conforme descrito mais à frente. 


\subsubsection{Presença de marcador de degeneração neuronal nos sistemas de co-cultura}

Após 5 dias de co-cultura, as lamínulas foram lavadas com PBS e fixadas com paraformaldeído a $4 \%$ por 1 hora. A permeabilização e a marcação com FluoroJade $C$ foram realizadas exatamente como descrito acima. Após a marcação, as lamínulas foram montadas com MONTEX contendo DAPI (Vector) para observação dos núcleos em azul. Em seguida as lâminas foram observadas em microscópio fluorescente para quantificação.

\subsection{Quantificações estereológicas}

\subsubsection{Quantificações estereológicas em contraste de fase nas células sob tratamento de meio condicionado}

As culturas neuronais tratadas com o respectivo meio condicionado de microglia TG ou WT ou então o meio de cultivo neuronal foram fotografados. As fotografias foram feitas em microscópio invertido, com objetiva de 40x sob contraste de fase em 6 campos equidistantes entre si. $O$ número de neurônios e a área dos prolongamentos por neurônio foram determinados em cada animal utilizando ferramenta esterológica específica acoplada às imagens, segundo procedimento de rotina no nosso laboratório (Gomide e Chadi, 1999; Levy, 2008).

Após o procedimento de coleta das imagens, estas foram transferidas para o computador $\mathrm{e}$ as células analisadas quantitativamente através do método estereológico. A moldura de contagem das células vivas formada por número definido de pontos (675 pontos) com área definida $\left(4,9 \times 10^{5} \mu \mathrm{m}^{2}\right)$ foi sobreposta às imagens coletadas dos 6 campos da placa. Todos os prolongamentos neuronais e regiões dos corpos celulares dos neurônios que atingiram os pontos da moldura foram contados. A somatória dos pontos contados resultou na área dos prolongamentos de cada campo. $\mathrm{O}$ número 
médio de neurônios presentes nos campos também foi obtido. As áreas médias dos prolongamentos neuronais encontrados nos 6 campos quantificados foram obtidas e divididas pelo número de pontos existente da moldura, resultando assim na Areal Fraction (AA). A AA média dos prolongamentos foi então dividida pelo número médio dos corpos celulares para que, então, os resultados fossem expressos em função do número dos corpos celulares. Este procedimento foi realizado em todas as placas de cultura por grupo experimental. Em seguida, os resultados do $5^{\circ}$ dia de tratamento foram expressos como porcentagem em relação aos resultados obtidos antes do tratamento com meio condicionado (pré-tratamento). Esta abordagem permitiu obter uma visão geral sobre o crescimento dos prolongamentos dos neurônios tratados em relação aquele período que não receberam tratamento. A média e o erro padrão dos grupos foram calculados.

\subsubsection{Quantificação estereológica para a pureza das culturas}

O procedimento para quantificação de pureza das culturas tanto neuronais quanto microgliais foi o mesmo, quantificando as células ChAT positivas, indicando neurônios e ChAT negativas coradas apenas com DAPI evidenciando os núcleos de outras células contaminantes ou $\mathrm{Cd} 11 \mathrm{~b}$ positivas como microglias e GFAP positivas como astrócitos contaminantes, deste modo foi possível obter a porcentagem de células contaminantes em cada cultura.

\subsubsection{Quantificações estereológicas em microscópio de fluorescência} da morte neuronal provocada pelo tratamento com meio condicionado

As imagens de 6 campos equidistantes entre si de cada poço de cultura neuronal obtido para a análise da morte neuronal após a marcação dos neurônios com FluoroJade $\mathrm{C}$ e submetidos ao tratamento com meios 
condicionados, também foram quantificadas por método estereológico específico. Uma moldura de 432 pontos com distância de $30 \mu \mathrm{m}^{2}$ foi desenhada e sobreposta às imagens fotografadas em microscópio de fluorescência sob o aumento de 20x. Todos os corpos celulares que estavam marcados em verde indicando processo de neurodegeneração foram contados, assim como todos os núcleos celulares, marcados em azul com DAPI. Deste modo, os corpos celulares marcados foram expressos pela quantidade de núcleos, resultando na porcentagem de células em degeneração existente em cada imagem. A média de cada grupo foi obtida.

\subsection{Seleção das moléculas do estudo}

Para definir as moléculas objeto do estudo com potencial para participar do processo neurodegenerativo da ELA, foram utilizados os resultados dos experimentos de microarray feitos no laboratório a partir de amostras de RNA da medula espinal de animais WT e TG nas idades de 40 e 80 dias que antecedem os sintomas clássicos da doença. A plataforma utilizada continha 44000 genes, correspondentes ao genoma completo do camundongo. Os resultados obtidos foram analisados sob o ponto de vista dos aspectos funcionais desses genes diferencialmente expressos através da ferramenta DAVID (http://david.abcc.ncifcrf.gov) que organiza os dados de acordo com as famílias de genes, funções moleculares, processos biológicos, componente celular, classe da proteína, vias de sinalização e relação em doenças neurodegenerativas. Em seguida, nosso laboratório se empenhou na seleção de genes de possíveis candidatos a participarem do processo neurodegenerativo da ELA e este trabalho revisou a análise no contexto das ações mirogliais. Para isso, foi levada em consideração a diferença de expressão do TG em relação ao WT (fold relativo), a importância do gene para a sinalização parácrina na sobrevivência neuronal, funções moleculares, processos biológicos, via de sinalização, relevância na literatura e contextualização com a microglia. 


\subsection{Quantificação de moléculas secretadas no meio condicionado microglial através do ELISA}

A análise da literatura indicou algumas moléculas solúveis secretadas pela microglia que pudessem ser quantificadas no meio condicionado e objetos deste estudo (Anexo B). As quantificações do NGF (Chemicon), do IGF e da endotelina 1 (ET-1) (Uscn) nos meios condicionados microgliais foram realizadas através da técnica ELISA sanduíche de acordo com as recomendações dos respectivos fabricantes e lidas no espectofotômetro (BioTek). Já as quantificações do TNFa, do VEGF e da IL-6 (Chemicon) foram realizadas através da mesma técnica, porém lidas através de um aparelho Luminex (Chemicon) através da tecnologia MULTIPLEX.

Todas as amostras de meio condicionadoforam coletadas 48 horas após a estimulação com LPS, centrifugadas e armazenadas em alíquotas de 100 e $200 \mu \mathrm{l}$ à $-80^{\circ} \mathrm{C}$ até serem utilizadas ( $\mathrm{n}>3$ para todos os grupos). Resumidamente, para o método de ELISA sanduíche convencional as amostras, os calibradores e a curva de diluição que foi realizada com diluições conhecidas da proteína recombinante, foram incubados em poços pré-sensibilizados com o antígeno de interesse. Em seguida os poços foram incubados com o conjugado enzimático para amplificação da leitura. Entre as incubações, lavagens foram realizadas de modo a remover componentes não reativos e restos de anticorpos não ligados. Em seguida, o substrato TMB foi adicionado, que reage com o conjugado enzimático produzindo cor que foi medida no espectofotômetro. Após a adição de uma solução que interrompe a reação, foi determinada a densidade óptica de cada poço, medindo a absorbância em espectrofotômetro a $\lambda=450 \mathrm{~nm}$.

A técnica de ELISA com a tecnologia MULTIPLEX foi realizada para a quantificação dos outros analitos (TNFa, VEGF e IL-6). Cada um desses anticorpos veio conjugado a microesferas de cores diferentes. O conjunto de microesferas foi incubado com as amostras ou com os padrões nos 
respectivos poços da placa. Em seguida, os anticorpos de detecção que eram biotinilados, foram adicionados. Assim, cada conjunto de microesferas se acoplou ao anticorpo de detecção correspondente e ao analito em questão presente em cada amostra. Para amplificação do sinal, foi adicionado o conjugado estreptavidina-ficoeritrina que se ligou ao repórter biotinilado e emitiu o sinal fluorescente que foi lido através de um feixe de laser específico para cada cor no aparelho Luminex.

Para ambos os métodos, a determinação da concentração dos antígenos em cada amostra foi realizada a partir da curva de diluições seriadas com concentrações conhecidas e preparadas com o anticorpo em questão de cada kit e expressa em pg/ $\mu$ l.

Utilizou-se ainda um controle para validação de cada kit. Esse controle foi constituído por dois padrões, um de concentração elevada e um padrão de baixa concentração. Tais concentrações conhecidas foram lidas e comparadas com os valores da curva.

\subsection{Extração e amplificação do RNA das culturas microgliais}

Dois dias após a ativação promovida pelo LPS $(1 \mu \mathrm{g} / \mathrm{ml})$ das culturas microgliais (desidade de 2,5 $\times 10^{4}$ ), foram lavadas com PBS para retirada do

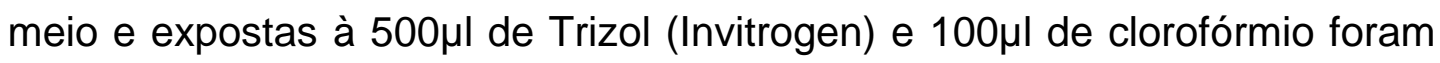
adicionados aos tubos e, em seguida, foram submetidos a agitação vigorosa. Cinco minutos após, os tubos foram centrifugados a $12000 \mathrm{~g}$ por $15 \mathrm{~min}$ à $4^{\circ} \mathrm{C}$. A fase aquosa foi transferida para outro tubo ao qual foi adicionado $500 \mu$ de isopropanol. Os tubos foram agitados por inversão com o intuito de precipitar o RNA.

Após pernoitarem em freezer $-80^{\circ} \mathrm{C}$, os tubos foram descongelados em temperatura ambiente e centrifugados por 30 minutos a 14000 rpm à $4^{\circ} \mathrm{C}$. Após a centrifugação, os sobrenadantes foram descartados e $500 \mu \mathrm{l}$ de álcool $80 \%$ foram adicionados aosprecipitados. Tal conteúdo foi submetido 
ao vórtex e centrifugado novamente por 15 minutos a $12500 \mathrm{rpm}$ à $4^{\circ} \mathrm{C}$. Esse procedimento de lavagem, vórtex e centrifugação se repetiu por 2 vezes, sendo que na última, após a centrifugação o precipitado foi seco e eluído em $10 \mu \mathrm{l}$ de água livre de nucleotídeos. A quantificação foi feita da concentração do RNA no aparelho espectrofotômetro NanoDrop 2000 (Thermo Scientific) e o tubo estocado em freezer $-80^{\circ} \mathrm{C}$.

As amostras foram descongeladas e o RNA total foi amplificado empregando-se o kit Message Amp II aRNA de acordo com recomendações do fabricante (Ambion). O protocolo usado para amplificação baseia-se na amplificação guiada pela T7-RNA polimerase e promotor T7. Resumidamente, o cDNA foi sintetizado a partir do RNA total, utilizando-se oligonucleotídeos que ancoram na cauda poli-A dos RNA mensageiros e possuem sítio de ligação para T7 RNA Polimerase. Para uma produção exponencial de RNA, este cDNA foi submetido à transcrição in vitro durante a amplificação. Todos os reagentes utilizados fazem parte do kit. O RNA amplificado foi quantificado pelo NanoDrop 1000 (Thermo) e a qualidade da amplificação foi avaliada com o kit Pico6000 Bioanalyzer (Agilent) que avalia a integridade do RNA.

\subsection{PCR em tempo real}

As reações de PCR em tempo real foram realizadas após a análise dos dados de microarray. Os PCRs em tempo real foram realizados com ensaios inventoriados Taqman na maioria dos genes selecionados e SYBR do gene da NTF5 com a sequência 5'3' GCACTGGCTCTCAGAATGCAA e GAPDH com a sequência 5'3' CGGCACAGTCAAGGC e eficiência de 102 e 92,3\% respectivamente. Os genes HIPK3 (Mm01278553_g1), AKAP13 (Mm01320098_m1), NKRF (Mm01297400_m1) e UBE2I (Mm04243971_g1) tiveram sua expressão quantificada por Taqman e o GAPDH (Mm99999915_g1) foi utilizado como controle endógeno. Os ensaios foram realizados no aparelho StepOnePlus ${ }^{\mathrm{TM}}$ Real-Time PCR System (Applied 
Biosystems). As reações foram realizadas nas condições universais de ciclagem: 10 minutos à $95^{\circ} \mathrm{C}$ para a ativação da enzima Maxima $\AA^{\circ}$ Hot Start Taq DNA Polymerase, seguidos de 50 ciclos de desnaturação à $95^{\circ} \mathrm{C}$ durante 15 segundos e um minuto a $60^{\circ} \mathrm{C}$ para o pareamento dos iniciadores e extensão. Foi adicionada uma etapa de 20 minutos de duração ao final da amplificação, na qual a temperatura aumenta gradualmente de $60^{\circ} \mathrm{C}$ para $95^{\circ} \mathrm{C}$ a $0,3^{\circ} \mathrm{C}$ por segundo com a contínua aquisição da fluorescência (Morrison et al., 1998), a partir da qual se obtém uma curva de dissociação, na qual a presença de um pico único confirma a especificidade da amplificação. As moléculas de SYBR emitem sinal fluorescente ao intercalar do DNA de fita dupla, enquanto no sistema Taqman a emissão fluorescente depende de uma sonda que se anela especificamente nos nucleotídeos.

Uma vez que a cada ciclo da reação (tanto Taqman quanto SYBR) novas moléculas de fita dupla são formadas, o nível de fluorescência emitida aumenta gradualmente, sendo que quanto menor o ciclo em que a fluorescência atinge um determinado limite, maior é o nível de expressão do transcrito analisado (Morrison et al., 1998). O parâmetro utilizado é o Ct (Cycle Threshold ou ciclo limite), uma linha aleatória fixa na região exponencial das reações e usada para determinar o ciclo em que cada amostra atinge determinado valor de fluorescência (Livak e Schmittgen, 2001). As reações, realizadas em duplicata, aceitaram valores de desvio padrão até 0,5 e foram repetidas quando ultrapassaram esse valor.

A expressão diferencial dos transcritos alvo foi determinada pela quantificação relativa em relação à média de GAPDH, uma vez que os experimentos de microarray não apontaram expressão diferencial entre transgênicos e selvagens para este gene em nenhuma das idades analisadas. Para cálculo da medida relativa de expressão foi utilizado o modelo matemático $2^{(-\Delta \Delta C t)}$. 


\section{Análise estatística}

A análise estatística foi realizada utilizando-se o programa Graph Pad Prism, versão 5 para Windows (Graph Pad Software, San Diego, Califórnia, USA).

Todos os dados obtidos foram analisados através dos métodos estatísticos não paramétricos do teste $t$ de Student ou análise de variância ( $A N O V A)$ de uma via, dependendo do caso, o que será relatado no momento da apresentação de cada resultado. Variações significativas foram aceitas em que a diferença entre os grupos resultou em um $p$ menor ou igual a 0,05. Os resultados estão apresentados como média aritmética \pm erro padrão da média. 


\section{Resultados}

\subsection{Pureza da cultura neuronal}

As culturas de neurônios motores da medula espinal de amundongos neonatos WT e TG foram devidamente purificadas. A Figura 2 ilustra estas células através de imagens por contraste de fase $(A)$ e imunomarcadas com ChAT, específico para neurônios motores (B). A razão entre os perfis nucleares das células ChAT positivos pelo número total de núcleos celulares das células foi de $80 \%$ oque denota culturas purificadas de neurônios motores obtidos neste trabalho (Figura 3).
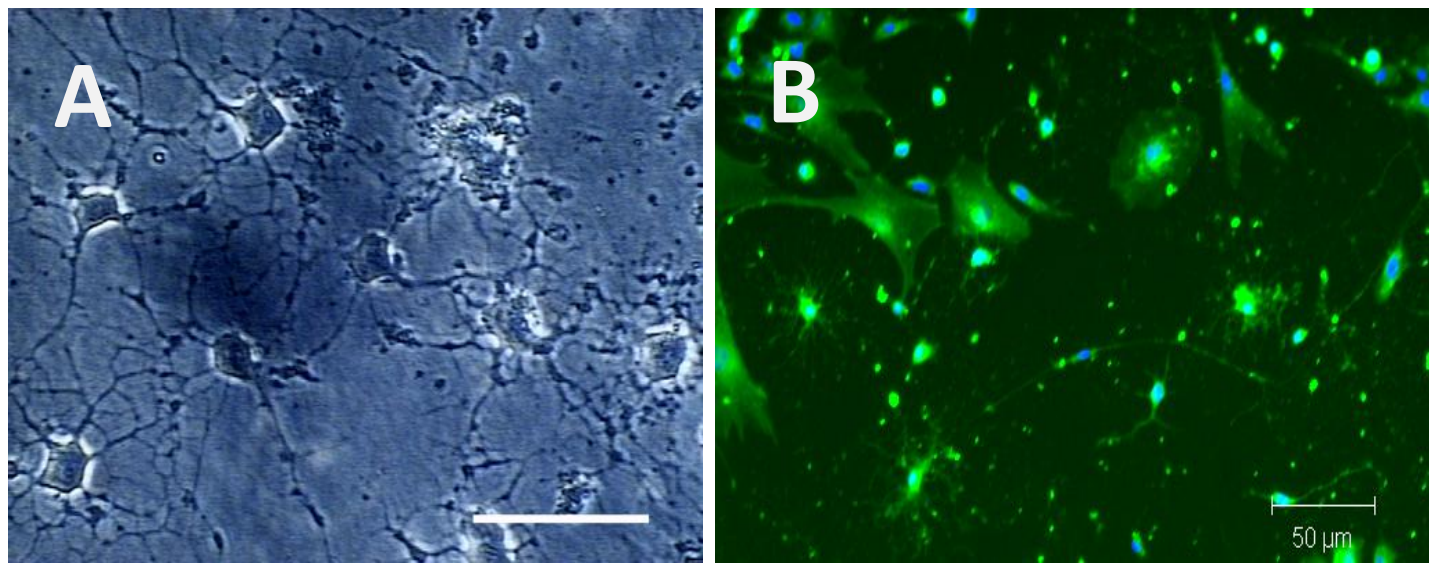

Figura 2. Fotomicrografias representativas de cultura de neurônios motores obtidas em microscópio de contraste de fase $(A)$ e de fluorescência (B). Pode se observar neurônios motores com prolongamentos longos e ramificados, estes estabelecendo contatos entre si (A). Ainda estes neurônios quando avaliados à imunofluorescencia mostraram o citoplasma fortemente imunorreativo ao $\operatorname{ChAT}(B)$, que indica a pureza da cultura, já que não há núcleos sem marcação do corpo celular (Chat negativo). Barras: 50 $\mu \mathrm{m}$. 


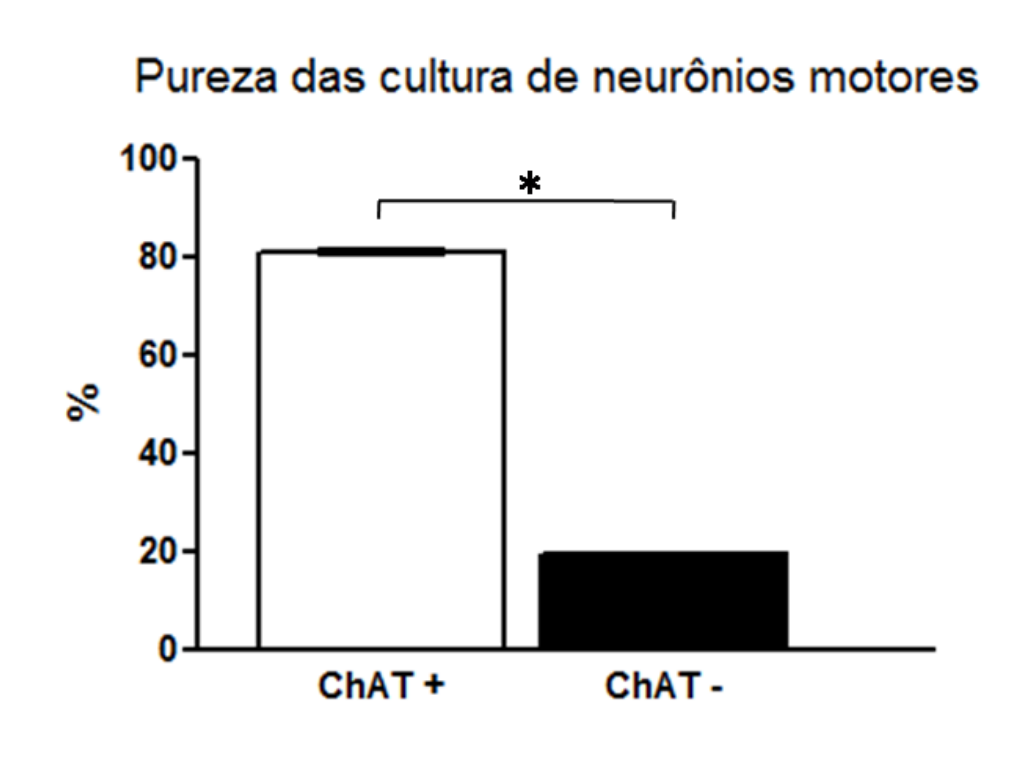

Figura 3. Gráfico mostra a presença de $80 \%$ de células ChAT imunorreativas (ChAT+) e $20 \%$ de células desprovidas desta imunorreatividade (ChAT-) na cultura de neurônios motores deste trabalho. Todas as células tiveram seus núcleos marcados com DAPI. ${ }^{*} \mathrm{p}<0,001$, segundo o teste $t$ de Student.

\subsection{Pureza da cultura de microglia neonatal}

As microglias obtidas da medula espinal dos camundongos TG e WT foram plaqueadas em lamínulas de vidro e submetidas à imunocitoquímica comos anticorpos contra o Cd11b, específico para microglia e a GFAP, específico para astrócito (Figura 4). Após a imunomarcação, as culturas foram fotografadas e as células quantificadas por método estereológico específico como descrito no método. O resultado foi expresso em porcentagem como mostra a Figura 5. Foi possível considerar a cultura microglial neonatal altamente purificada, observando $93 \%$ da população celular composta por microglia Cd11b imunopositivas e 6\% de astrócitos GFAP imunopositivos. 


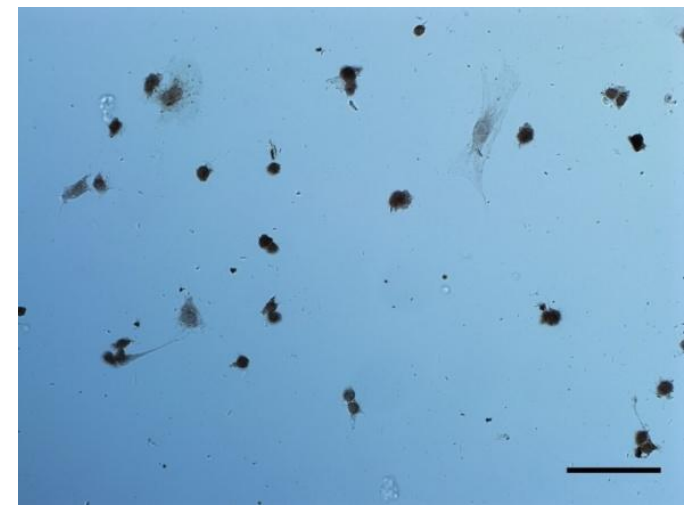

Figura 4. Fotomicrografia de cultura microglial proveniente de neonatos (P1). Microglias

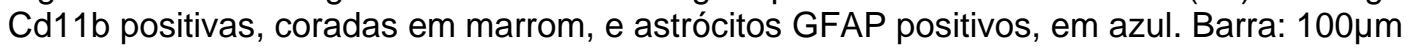

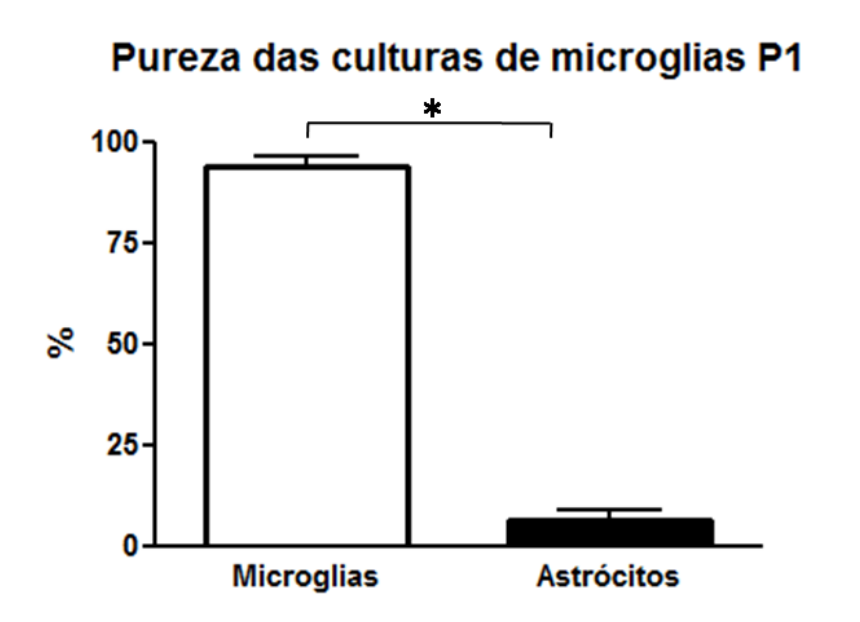

Figura 5. Gráfico mostra a porcentagem da população de microglia imunopositiva ao Cd11b e astrócito imunopositivo à GFAP na cultura microglial de camundongos neonatos (P1). Diferença estatística $\left({ }^{*} p<0,001\right)$ foi observada segundo o teste $t$ de Student entre as duas populações de células.

Ainda, para a certificação adicional da pureza das culturas de miroglias P1, a PCR semi-quantitativa foi realizada, empregando iniciadores específicos para microglia (Cd11b) e astrócito (GFAP), bem como o gene da molécula constitutiva GAPDH que foi utilizado como controle. A comparação das bandas do Cd11b com aquela do GFAP, a primeira que representa as células microgliais, é mais intensa do que a dos astrócitos, denotando a presença maioritária da microglia nestas culturas (Figura 6). 


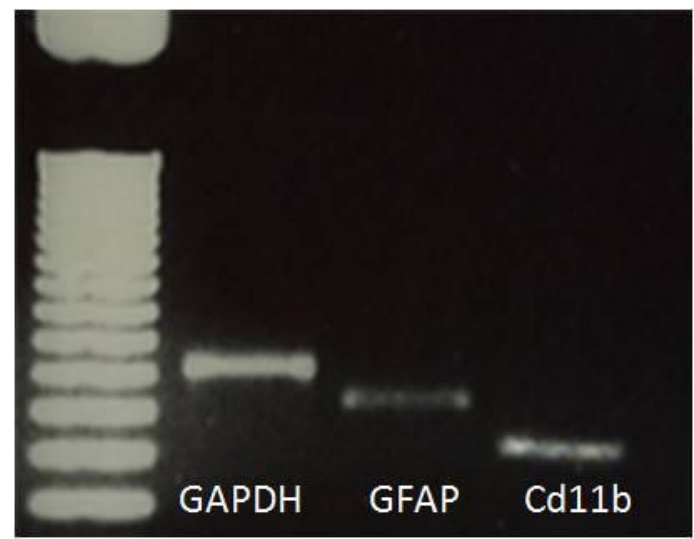

Figura 6. Representação das bandas obtidas em gel de agarose corado com brometo de etídeo para as PCRs dos genes GAPDH (308 pares de base), GFAP (260 pares de base) e Cd11b (135 pares de base). Observa-se que a banda do Cd11b é mais intensa que aquela da GFAP.

\subsection{Pureza da microglia proveniente do camundongo adulto}

As microglias cultivadas provenientes da medula espinal de camundongos WT e TG em idade P60, plaqueadas em lamínulas de vidro e submetidas à imunocitoquímica do Cd11b, específico para microglia, e da GFAP, específica para astrócito, são ilustradas na Figura 7. Após a imunomarcação, as células foram fotografadas e quantificadas por método estereológico específico. O resultado foi expresso em porcentagem, como mostra a Figura 8. Foi possível observar que a grande maioria da população celular da cultura, $90 \%$ é composta por microglia Cd11b imunopositivas, enquanto apenas $10 \%$ dessa população é composta por astrócitos GFAP imunopositivos. 


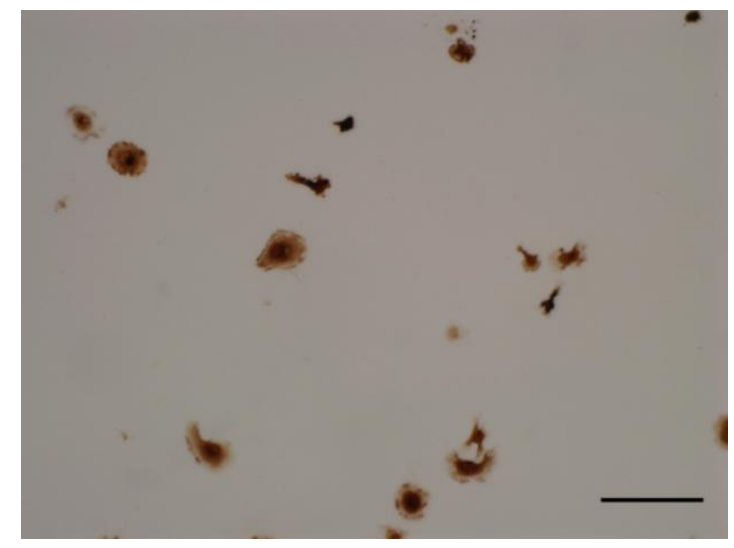

Figura 7. Fotomicrografia de cultura de microglial proveniente de medula espinal de camundongos adultos pré sintomáticos (P60). Microglias $\mathrm{Cd} 11 \mathrm{~b}$ positivas, coradas em marrom, e astrócitos GFAP positivos, em azul. Barra: $100 \mu \mathrm{m}$

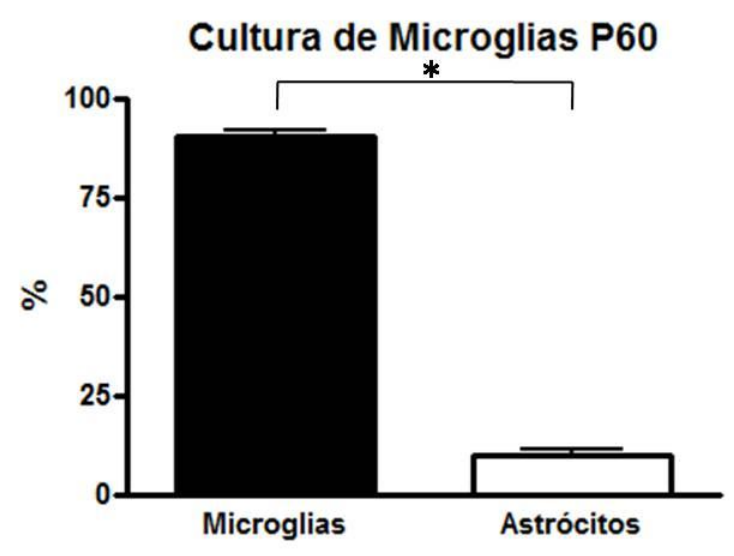

Figura 8. Gráfico mostra a porcentagem da população de miroglia imunopositiva ao Cd11b e de astrócito imunopositivo à GFAP na cultura microglial de camundongos adultos pré sintomáticos (P60). Diferença estatística $\left({ }^{*} p<0,001\right)$ foi observada segundo o teste $t$ de Student entre as duas populações de células.

\subsection{Análise do trofismo do neurônio na presença do meio condicionado de microglia sem ativação pelo LPS}

A análise dos dados obtidos com as quantificações dos prolongamentos neuronais em cultura mostra que os neurônios estavam saudáveis até $05^{0}$ dia de tratamento, já que seus prolongamentos aumentavam na medida em que todas as amostras mostraram valores superiores a $100 \%$ o que indica que o tempo influencia nos prolongamentos neuronais, dado confirmado pelo teste ANOVA com pós-teste de Bonferroni. 
Os neurônios WT e TG tratados com MC de miroglia WT e TG tanto de P1 quanto $\mathrm{P} 60$, apresentaram quantidades de prolongamentos que não diferenciaram das culturas equivalentes tratadas com meio neuronal, como demonstrado pelo teste ANOVA com pós-teste de Bonferroni (Figura 9). De modo semelhante, as culturas de neurônios WT e TG tratadas com MC de microglia TG, tanto aquelas derivadas de $\mathrm{P} 1$ quanto as de $\mathrm{P} 60$, não apresentaram quantidade de prolongamentos diferentes daquelas culturas equivalentes tratadas com o MC de miroglia WT (Figura 9).
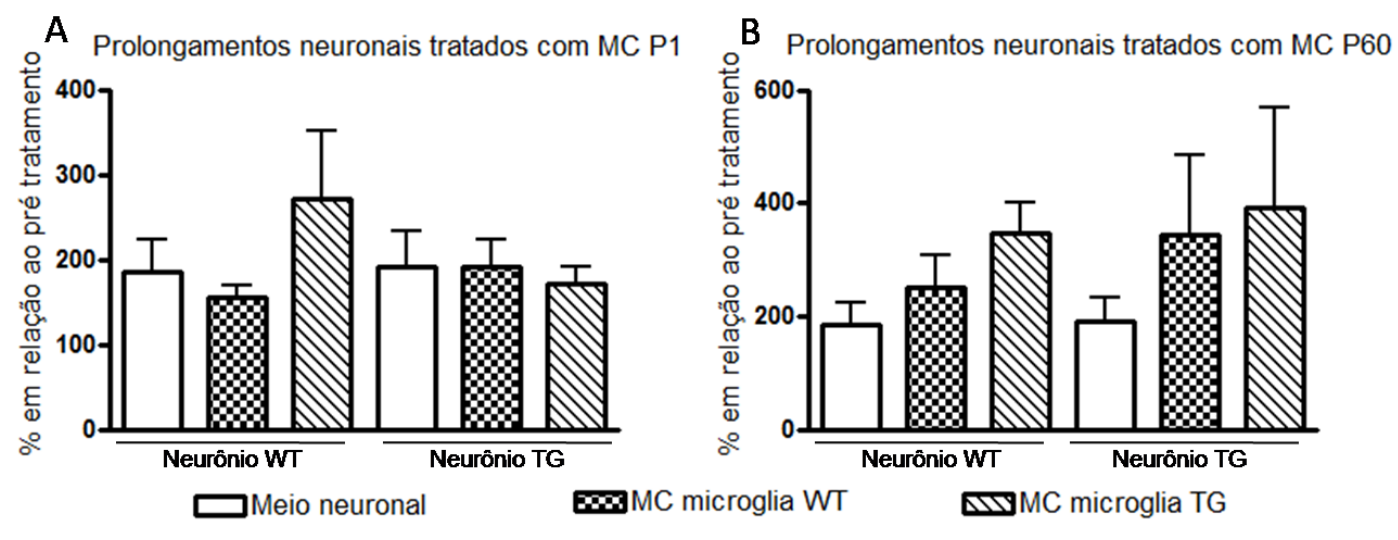

Figura 9. A figura mostra a quantidade de prolongamentos no $5^{\circ}$ dia de culturas de neurônios motores de animais wild-type (WT) e transgênicos (TG) após os tratamentos com os meios condicionados (MC) de microglias de camundongos em P1 (A) e P60 (B) expressa em porcentagem dos respectivos valores encontrados imediatamente antes dos tratamentos. As culturas microgliais não recebram o tratamento com LPS. Para controle do procedimento, culturas adicionais de neurônios motores de animais WT e TG foram tratadas com meio neuronal, seguindo os mesmos parâmetros daquelas tratadas com MC. Para detalhes do tratamento consultar o texto. Ausência de diferença estatística pelo teste ANOVA de uma via com pós-teste de Bonferroni

\subsection{Ativação microglial com LPS e avaliação de seu estado ativo}

A ausência de efeitos tóxicos dos $M C$ de microglias não tratadas pelo LPS aos neurônios motores cultivados reafirmou a necessidade de ativação das mesmas e análise dos efeitos dos seus MC na quantidade de prolongamentos de neurônios motores.

Para observar o comportamento microglial no seu estado ativo, testes foram realizados para verificar qual a concentração de LPS que resultaria em uma ativação ideal. As culturas de microglias WT e TG (P1 e P60) 
tratadas com as concentrações de 1 e $10 \mu \mathrm{g} / \mathrm{ml}$ de LPS tiveram a concentração de NO secretada quantificada em seus MCs pelo método de Griess (descrito em detalhes no método) para análise do grau de ativação promovido. O gráfico abaixo (Figura 10) representa os meios condicionados microgliais WT e TG nas duas idades sem tratamento de LPS, e nas duas concentrações testadas.

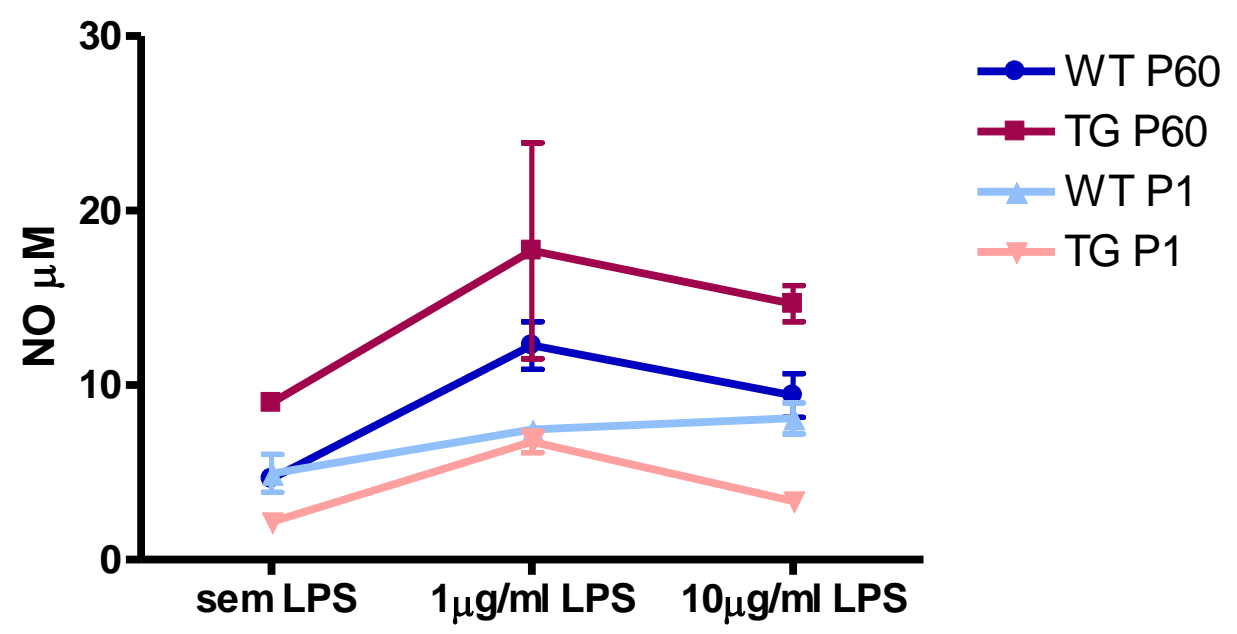

Figura 10. Gráfico representa a quantidade de Óxido Nítrico (NO) secretada pelas microglias wild type (WT) transgênicas (TG) de culturas de animais neonatos (P1) e adultos (P60) sem ou através da ativação com1 ou $10 \mu \mathrm{g} / \mathrm{ml}$ de LPS. $\mathrm{n}=6$ para cada grupo.

O LPS na concentração de $1 \mu \mathrm{g} / \mathrm{ml}$ induziu a secreção de quantidades maiores de NO pelas miroglias de ambas as idades e genótipos (Figura 10) o que orientou a utilização dessa concentração nas análises dos efeitos tóxicos das miroglias P1 e P60 de animais WT e TG aos neurônios motores cultivados, como descrito a seguir.

A análise dos dados da figura 10 mostrou também que os MCs da microglia TG P60 apresentaram quantificação maior de NO em relação aos controles WT mesmo sem ativação com LPS $(84,4 \%)$ e com $1 \mu \mathrm{g}$ de LPS $(55,6 \%)$, sendo que a diferença estatística não foi conseguida nesta última devido à variabilidade entre os ensaios (Figura 11). 

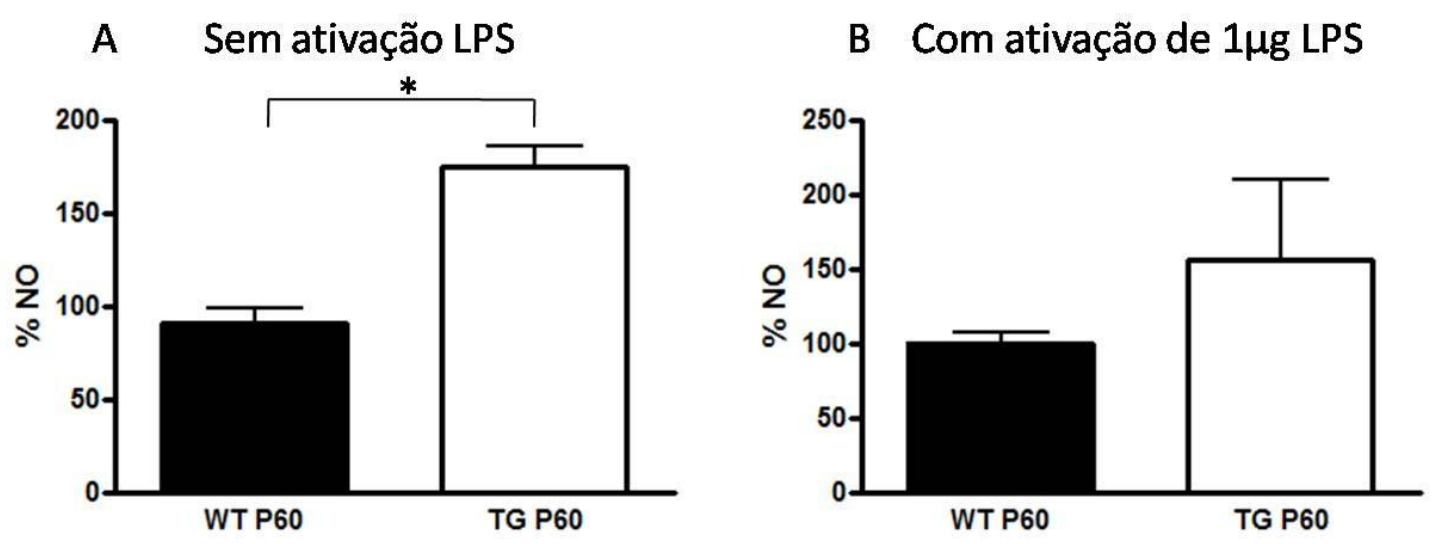

Figura 11. Quantidade de NO no meio condicionado de microglia de animais WT e TG de 60 dias de vida (P60) sem (A) e com (B) o tratamento com LPS. Detalhes dos trabalhos e das culturas são encontrados no texto. Os dados foram expressos pela concetração de NO da miroglia TG em relação à concentração de NO seretada pela miroglia WT. Diferença estatística $\left({ }^{*} p<0,05\right)$ foi observada segundo o teste $t$ de Student entre a concentração de NO secretada pela microglia TG P60 comparada a WT da mesma idade sem ativação pelo LPS.

\subsection{Análise do trofismo do neurônio na presença do meio condicionado de microglia com ativação do LPS}

Prolongamentos neuronais foram observados vinte e quatro horas após o tratamento das culturas de neurônios WT e TG com meio neuronal e MC de miroglias WT e TG, de animais P1 e P60, tratadas com LPS. Entretanto diferenças aparentes entre os tratamentos não foram detectados com os meios condicionados provenientes de microglias P1 (Figura 12A).

Adicionalmente as culturas de neurônios tratadas com o $M C$ de microglias WT P60 ativadas pelo LPS mostraram maior extensão de prolongamentos neuronais comparados aos neurônios que receberam meio neuronal como tratamento (306,2\% neurônios WT e 289,5\% neurônios TG tratados com MC microglias WT P60 em relação ao meio). Ainda, os neurônios WT tratados com MC microglia WT P60 apresentaram aumento de $178,8 \%$ nos seus prolongamentos em relação aos dos neurônios WT que receberam tratamento com MC de microglia TG (Figura 12B). 
A Prolongamentos neuronais tratados com MC P1

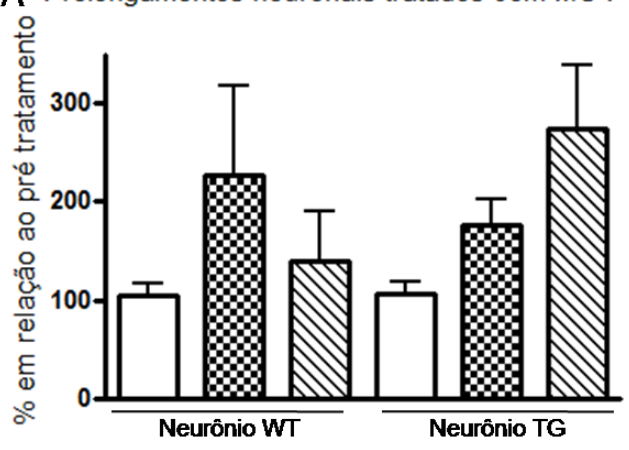

$\square$ Meio neuronal
B Prolongamentos neuronais tratados com MC P60

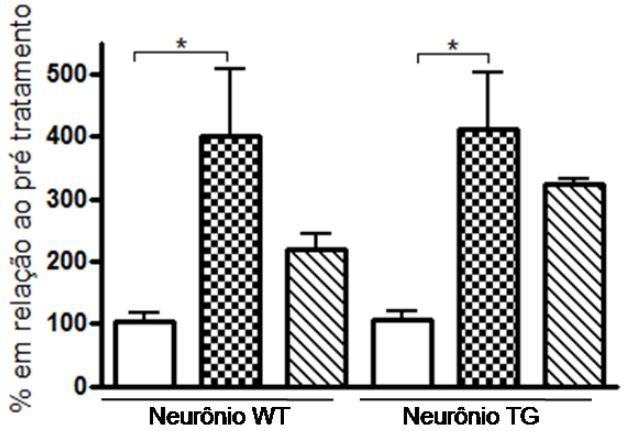

$\triangle \mathrm{MC}$ microglia TG

Figura 12. A figura mostra a quantidade de prolongamentos no $5^{\circ}$ dia de culturas de neurônios motores de animais wild-type (WT) e transgênicos (TG) após os tratamentos com os meios condicionados (MC) de microglias de camundongos em P1 (A) e P60 (B) ativadas com $1 \mu \mathrm{g} / \mathrm{ml}$ de LPS expressa em porcentagem dos respectivos valores encontrados imediatamente antes dos tratamentos. As culturas microgliais não receberam o tratamento com LPS. Para controle do procedimento, culturas adicionais de neurônios motores de animais WT e TG foram tratadas com meio neuronal, seguindo os mesmos parâmetros daquelas tratadas com MC. Para detalhes do tratamento consultar o texto. * $p<0,01$ segundo o teste ANOVA de uma via com pós-teste de Bonferroni.

\subsection{Presença de marcador de degeneração neuronal nos neurônios submetidos ao tratamento com meio condicionado de microglias ativadas pelo LPS}

As culturas de neurônios motores que receberam tratamento do meio condicionado microglial e foram submetidas à coloração com marcador de morte neuronal, FluoroJade C, estão ilustradas na Figura 13.

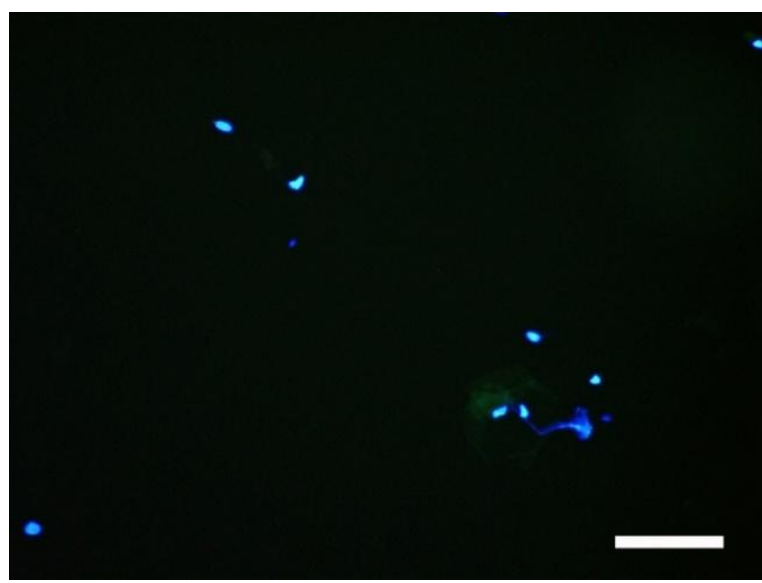

Figura 13. Fotomicrografia ilustra os neurônios motores cultivados marcados com FluoroJade C (verde) indicando processo de morte neuronal. Os núcleos marcados com DAPI (azul) indicam todos os neurônios presentes no campo fotográfico. Barra: 100um. 
Os valores da quantificação dos perfis neuronais FluoroJade $C$ posoitivos, indicativos de morte neuronal, e expressos em porcentagem relativa às células DAPI positivas, marcador nuclear de todas as células dos campos fotográficos, estão apresentados na figura 14. Observa-se que tanto as culturas de neurônios que foram tratadas com MC microglial P1 (Figura $14 \mathrm{~A})$ quanto àquelas tratadas com $M C$ da microglia $P 60$ (Figura 14B) não resultaram em diferença estatística entre os grupos, mostrando que os fatores secretados pelas microglias ativadas não foram capazes de promover a morte neuronal.

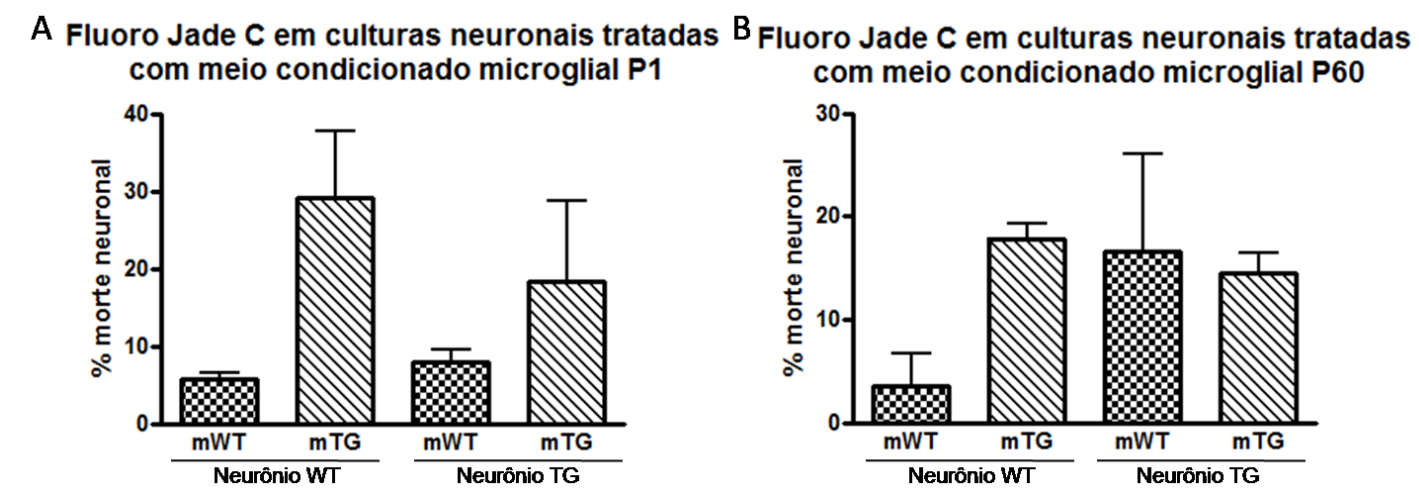

Figura 14. Gráficos mostram a porcentagem de morte neuronal, através da quantificação de perfis neuronais FluoroJade $C$ positivosno 5 o dia de tratamento dos neurônios WTe TG com os diferentes meios condicionados de microglias P1 (A) e P60 (B) wild type (mWT) e transgênicos (mTG) em relação à presença de perfis FluoroJade $C$ positivos antes dos tratamentos. Diferença estatística não foi observada segundo o teste ANOVA de uma via com pós-teste de Bonferroni.

\subsection{Análise da morte neuronal em co-culturas neurônio/microglia}

A Figura 15 mostra a presença dos dois perfis celulares em cocultura, notavelmente os neurônios motores imunomarcados com a ChAT (vermelho) e microglias, células menores, e imununomarcadas pelo anticorpo específico lba-1 (verde). 


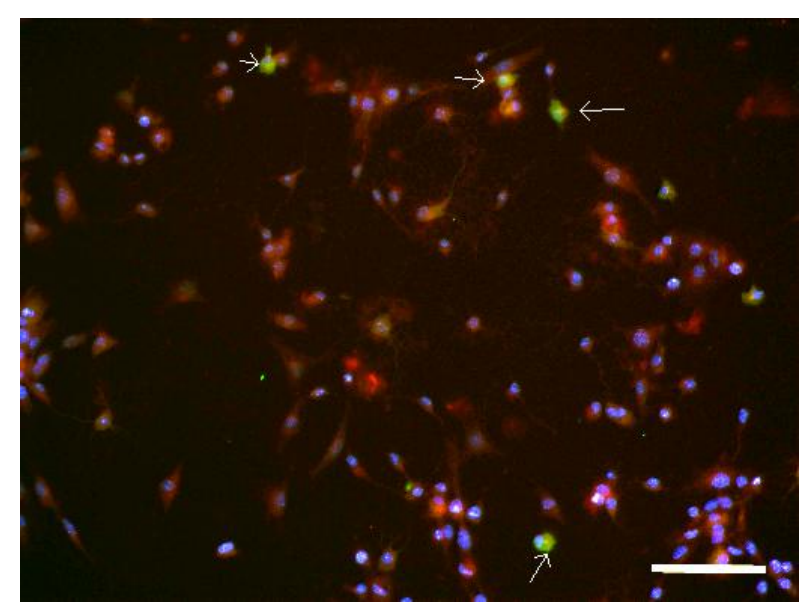

Figura 15. Fotomicrografia de imunofluorescênciacom dupla marcação imunohistoquímica no sistema de co-cultura neurônio/microglia. Neurônios motores ChAT imunopositivos (vermelho) e miroglias, indicadas pelas setas, Iba-1 imunopositivas (verde). Barra: 100 $\mu \mathrm{m}$.

As quantificações do número de neurônios motores FluoroJade $\mathrm{C}$ positivos nos sistemas de co-ultura com miroglias, indicando neurodegeneração, estão apontados na figura 16. Número maior de neurônios em degeneração foi observado quando os neurônios WT eram cultivados com microglias TG de P1 (6,14\%) ou P60 (4,61\%), quando comparado às co-culturas de neurônios WT com microglias WT (Figura 16A e B). Por outro lado, diferenças estatísticas não foram observadas quando as microglias TG (P1 e P60) eram co-cultivadas com neurônios TG, ainda em relação às co-culturas neurônio TG com miroglia WT (Figura 16A e B). 
A co-cultura neurônio/microglia P1

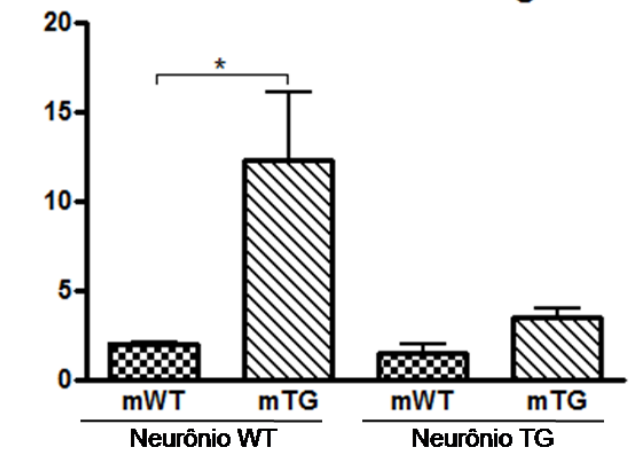

B co-cultura neurônio/microglia P60

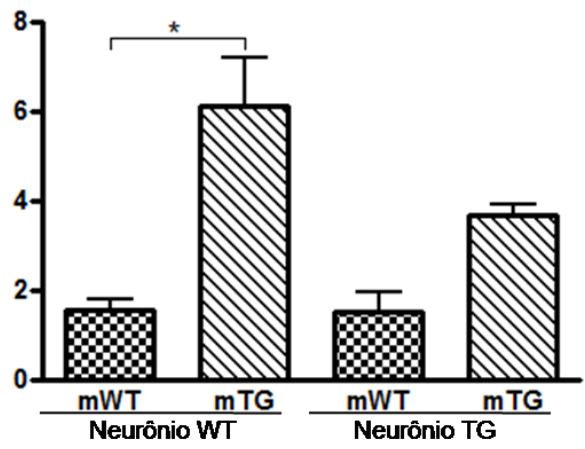

Figura 16. Gráficos mostram a porcentagem de morte neuronal marcada pelo FluoroJade $C$ no $5^{\circ}$ dia de tratamento dos neurônios WT e TG nos sistemas de co-cultura com microglias $\mathrm{P} 1$ (A) e P60 (B) em relação a morte neuronal observada antes dos tratamentos. Diferença estatística $\left({ }^{*} p<0,01\right)$ foi observada segundo o ANOVA de uma via com pós-teste de Bonferroni entre a quantidade de células FluoroJade $C$ positivas nas co-culturas de neurônios WT com microglias TG (mTG) comparado com a co-cultura de neurônios WT com miroglias WT (mWT) proveniente de animais nas ambas as idades analisadas.

\subsection{Seleção das moléculas a partir dos resultados do microarray}

Dos 44000 genes nos quais foram hibridizados o RNA da medula espinal de camundongos WT e TG de 40 e 80 dias, 1318 foram diferencialmente expressos $(p<0,05)$ no TG com 40 dias e 1314 no TG com 80 dias. A análise bioinformática pelo DAVID permitiu selecionar os genes NKRF, HIPK3, UBE2I, AKAP13, NTF5, NTRK1, NGFR, IRF-4, IGFBP4, VEFA, VEGFB, TEAD4 e EDNRA para serem avaliados por PCR em tempo real nas microglias cultivadas, bem como escolher as proteínas TNFa, VEGF, IL-6, IGF, NGF, ET-1 a serem quantificadas no meio condicionado destas culturas.

O anexo B representa as proteínas selecionadas para quantificação no meio condicionado microglial, o gene relacionado diferencialmene expresso no microarray com o repectivo fold relativo e os trabalhos e idéias principais que levaram a escolha de tal molécula. 
$\mathrm{O}$ anexo $\mathrm{C}$ mostra os genes selecionados para a quantificação da sua expressão nas microglias cultivadas, assim como o fold relativo e os trabalhos e idéias principais que levaram a eleição de tal gene.

\subsection{Quantificação das moléculas candidatas no meio condicionado microglial através da técnica de ELISA}

Os meios condicionados microgliais coletados 48 horas após 0 estímulo com $1 \mu \mathrm{g}$ de LPS foram submetidos aos ensaios disponíveis comercialmente de ELISA sanduíche para a quantificação dos níveis de TNFa, VEGF, IL-6, IGF, NGF, ET-1.

As quantificações dos níveis de TNFa no meio condicionado da cultura de microglia mostraram maior quantidade da citocina $(37,9 \%)$ secretada pelas microglias TG P60 quando comparada à WT da mesma idade (Figura 17A). Diferença estatística não foi observada nos níveis de TNFa nos meios condicionados das microglias WT e TG P1 (Figura 17A). Os meios condicionados das microglias TG P60 mostraram quantidades maiores de IL-6 quando comparadas às quantidades da citocina presente nos meios condicionados WT da mesma idade (94,9\%) e TG P1 $(91,6 \%)$ (Figura 17B). A quantidade de NGF presente no meio condicionado das microglias TG P60 (128,4\%) e WT P60 (71,8\%) se mostrou aumentada em relação às $\mathrm{P} 1$ dos mesmos genótipos e ainda a microglia TG $\mathrm{P} 1$ se mostrou secretando quantidade maior de NGF do que a WT $(29,6 \%)$ da mesma idade (Figura 17E). Ainda, notavelmente, as microglias TG secretaram maior quantidade de NGF do que as WT (Figura 17A). Com relação ao VEGF, IGF e ET-1 não foram encontradas diferenças estatísticas entre os grupos (Figura 17C, D, F). 
Moléculas secretadas no MC microglial
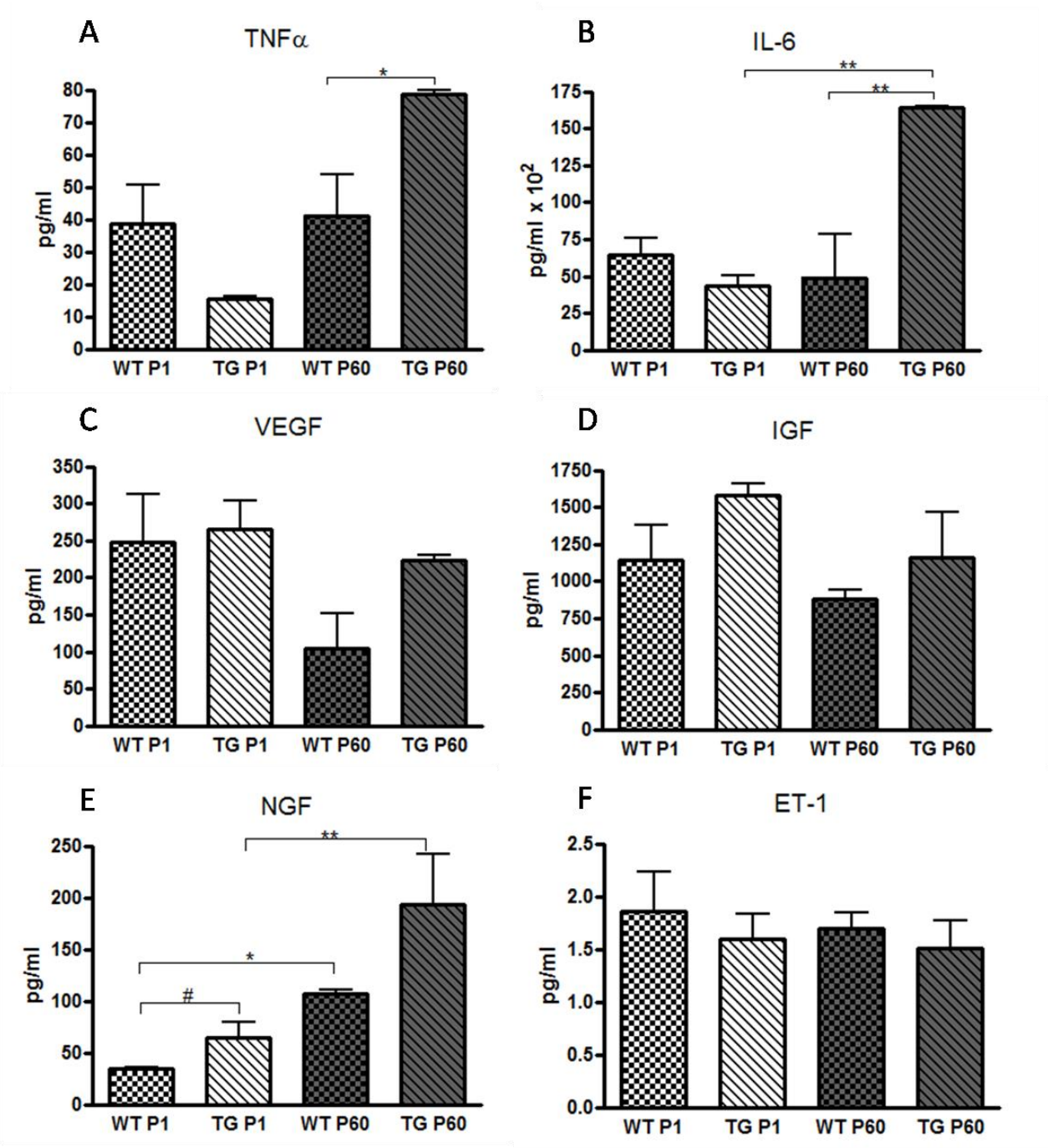

Figura 17. Gráficos mostram os níveis (pg/ml) de TNFa (A), IL-6 (B), VEGF (C), IGF (D), NGF (E) e ET-1 (F) quantificados pelo método de ELISA nos meios condicionados (MC) microgliais wild type (WT) e transgênicos (TG) provenientes de animais neonatais (P1) e com 60 dias (P60). Diferenças estatísticas $\left({ }^{*} p<0,01 e^{* *} p<0,001\right)$ foram observadas segundo - ANOVA de uma via com pós-teste de Bonferroni entre a quantidade de TNFa presente no MC da microglia TG P60 com a WT da mesma idade (A), entre a quantidade de IL-6 presente no MC da microglia TG P60 com a WT da mesma idade e com a TG P1 (B), entre a quantidade de NGF presente no MC da microglia TG P60 com a TG P1 e entre a WT P60 com a WT P1. Diferença estatística $(\# p<0,01)$ foi observada segundo o teste $t$ de Student entre a quantidade de NGF secretada pela microglia TG P1 com a microglia WT da mesma idade. 


\subsection{Quantificação da expressão gênica pela microglia cultivada através da técnica de PCR em tempo real}

Após a amplificação dos RNAs as expressões dos genes AKAP13, HIPK3, UBE2I, NKRF e NTF5 foram quantificadas nas microglias dos diferentes grupos. A Figura 18 representa a diferença de expressão relativa (fold relativo) entre a microglia WT e TG das idades diferentes.

A expressão do gene AKAP13 foi menor nas culturas de microglia TG P1 em relação às culturas de microglia WT P1(149,2\%) e TG P60 (199\%) (Figura 18A). Ainda, a expressão o HIPK3 também se mostrou diminuída nas culturas de microglia TG P1 (77\%) e WT P60 (65\%) (Figura 18B). O nível de expressão do gene UBE2l foi maior na microglia TG P60 (117\%). A análise da expressão do gene NKRF não mostrou diferenças estatísticas entre os grupos (Figura 18D). Finalmente, o nível de expressão do gene NTF5 pelas microglias TG $\mathrm{P} 1$ foi menor em relação aos WT da mesma idade $(52,6 \%)$ (Figura 18E). 

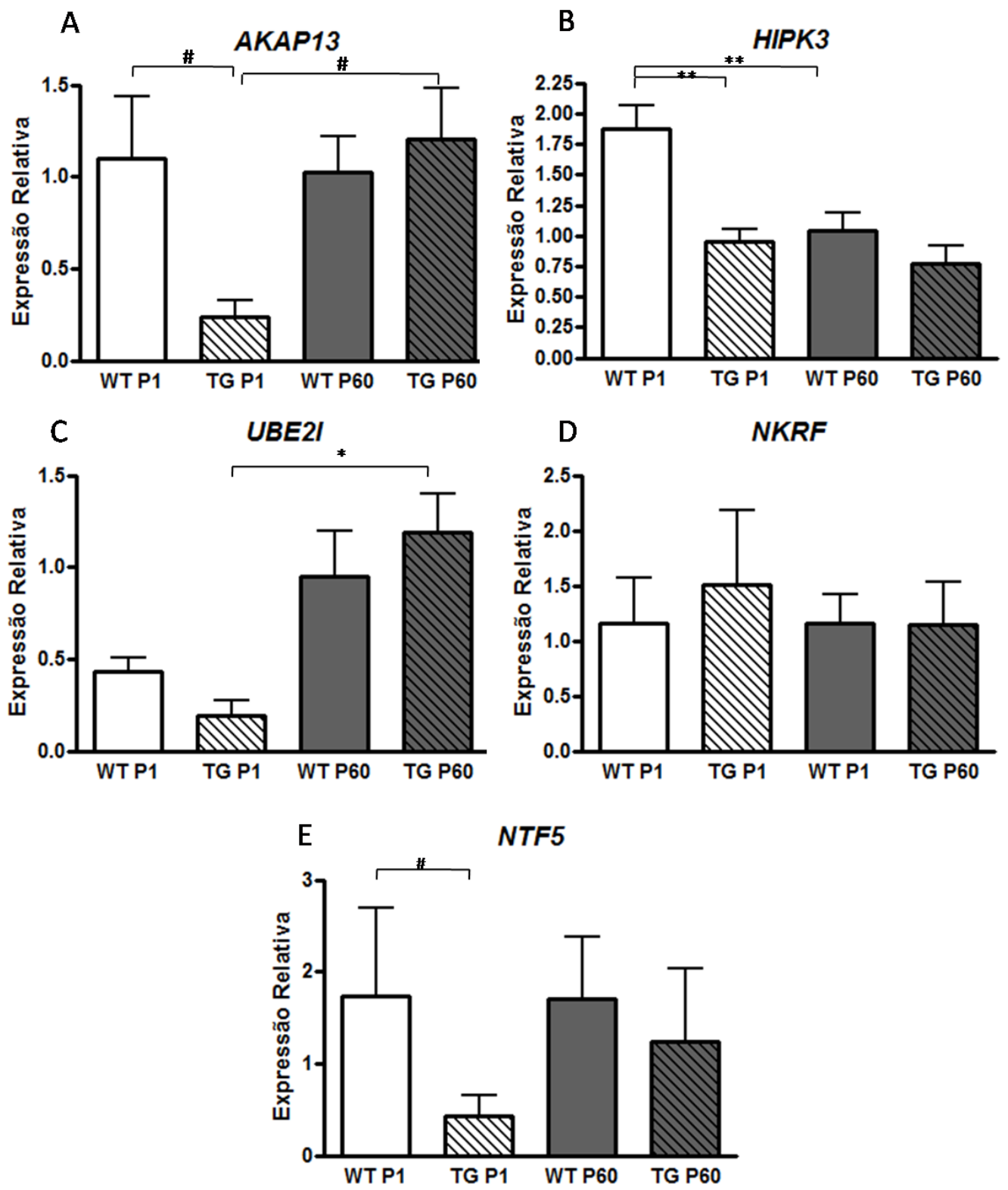

Figura 18. Gráficos mostram as diferenças de expressão relativa dos diferentes genes AKAP13 (A), HIPK3 (B), UBE2I (C), NKRF (D) nas culturas purificadas de microglia proveniente de camundongo wild type (WT) e transgênico (TG) de 1 (P1) e 60 (P60) dias pós natal. ${ }^{*} p<0,05 e^{* *} p<0,01$ segundo o ANOVA de uma via com pós-teste de Bonferroni. \# $p<0,05$, segundo o teste $t$ de Student. As diferenças estatísticas estão apontadas nos gráficos. 


\section{Discussão}

Muitos estudos indicam que a ELA é uma doença neurodegenerativa que envolve não somente os neurônios motores, mas também as células gliais que circundam a população neuronal (llieva et al., 2009). A microglia, em particular, contribui substancialmente para a progressão da doença (Boilee et al., 2006; Lobsiger et al., 2007; Neusch et al., 2007). A despeito das evidências do impacto da neuroinflamação na progressão da ELA, esse ainda é um tema pouco conhecido e entendido. O presente estudo buscou compreender melhor o papel da microglia na participação da degeneração do neurônio motor na doença.

A microglia no seu estado ativo desempenha funções necessárias para a manutenção da vida neuronal. Sua ativação também está envolvida na regulação do desenvolvimento do SNC e na neurogênese através da secreção de fatores tróficos e anti-inflamatórios (Hanisch e Kettenmann, 2007). Porém, em algumas circunstâncias, a microglia pode se tornar super ativada e induzir efeitos neurotóxicos diretos aos neurônios através da secreção de substâncias citotóxicas (Block e Hong, 2005). Estas, por sua vez, são capazes de ativar o astrócito, outra célula glial, e, através deste mecanismo, pode contribuir nos processos de morte neuronal (Rohl et al., 2007). No modelo animal, a redução da ativação microglial diminui o estado reativo dos astrócitos (Cernak et al., 2005; Gunther et al., 2005; Miller e McAllister, 2007). As células astrócitarias possuem receptores para muitos dos fatores inflamatórios secretados pela microglia (Zhang et al., 2010), mostrando que essas células são, de fato, responsivas à ativação microglial e, assim, podem estar desempenhando um efeito citotóxico aos neurônios (Nagai et al., 2007).

\subsection{Pureza das culturas de células}

Uma das dificuldades na determinação da contribuição da microglia na fisiopatologia da ELA é a complexidade das interações que ocorrem entre a mesma e os neurônios motores in vivo. Deste modo, os modelos in vitro 
são úteis na investigação dos efeitos funcionais de cada célula individualmente bem como a desregulação deles no caso de processos neurodegenerativos.

Dessa forma, a pureza das culturas celulares é necessária já que, a contaminação por outros tipos celulares pode trazer viéses (Scorisa et al., 2010). Trabalhos que utilizaram co-culturas de microglia com neurônio motor não descrevem os detalhes de pureza nas culturas, tanto microgliais quanto neuronais (Weydt et al., 2004; Nagai et al., 2007). Assim, os resultados obtidos podem ser influenciados pelos efeitos das células contaminantes nas culturas primárias e não da microglia em questão. As culturas obtidas neste trabalho apresentaram células microgliais ramificadas e de aspecto amebóide, semelhantes a outros estudos apresentados na literatura (Giulian e Baker, 1986). Observou-se que microglias WT e TG apresentaram morfologia semelhante, sugerindo que a presença da mutação da SOD1 não interfere com o fenótipo da célula (D’ambrosi et al., 2009).

\subsection{Análise do trofismo do neurônio na presença do meio condicionado de microglia}

O tratamento com meio condicionado da microglia não ativada com LPS mostrou que as moléculas secretadas tanto pela microglia TG quanto pela microglia WT não foram capazes de causar qualquer alteração nos prolongamentos neuronais dos dois genótipos. Nagai et al. (2007) mostraram que a presença da SOD1 ${ }^{\mathrm{G} 93 \mathrm{~A}}$ no neurônio motor não é capaz de influenciar per si a morte celular, sugerindo a necessidade da participação do astrócito neste processo.

Ao contrário do esperado, o tratamento com meio condicionado da microglia TG P1 sem ativação de LPS resultou em neurônios TG comprolongamentos ainda maiores do que as culturas neuronais WT tratadas com meio, porém sem diferença estatística. Trabalho publicado recentemente facilitou o entendimento deste efeito. Dijab et al. (2011) demonstraram em experimento in vivo a reação rápida das microglias TG 
após discreta lesão no SNC em animais pré-sintomáticos SOD1 ${ }^{\text {G93A }}$. Os autores descreveram a possibilidade da microglia TG buscar a reversão da lesão de modo mais rápido que a microglia não TG. Quando a lesão foi provocada nos animais TG mais velhos com 90 e 120 dias, por outro lado, a migração microglial não foi rápida para o sítio de lesão e não foi capaz de diminuir o dano tecidual. Esses autores destacaram duas fases diferentes de resposta microglial nesses animais. Nos estados pré-clínicos, a microglia se encontra reativa, indicando um aumento de resposta à lesão, já nos estágios tardios, a microglia perde seu papel dinâmico de vigilância do SNC, permitindo que a doença avance rapidamente. Dessa forma, nossos resultados corroboram com estas descrições, uma vez que o tratamento com o meio condicionado da microglia TG P1 mostrou grandes prolongamentos neuronais, diferente daqueles observados nos neurônios tratados com 0 meio condicionado da microglia $\mathrm{P} 60$, denotando as possíveis ações neurotróficas da microglia TG do animal neonato. A falta de diferença estatística nesse experimento pode ter ocorrido devido à variabilidade da amostra ou ao baixo número amostral.

Estes resultados em conjunto com outros trabalhos recentes da literatura (Weydt et al., 2004; Xiao et al., 2007) apontaram para a necessidade da ativação microglial, simulando a situação encontrada na desordem neurodegenerativa, similar à que ocorre na ELA. Já se sabe que a ativação microglial é decorrente do estado de disfunção neuronal (Morioka et al., 1991). Dados indicam que a microglia ativada secreta quantidades maiores de substâncias neurotóxicas e neurotróficas em relação à microglia quiescente, dependendo da situação fisiológica em que se encontra (Nakamura e Kataoka, 1999; Weydt et al., 2004). A ativação pelo LPS parece ser o mecanismo mais rápido, reprodutível e mais utilizado para ativar microglia in vitro (Das et al., 1995; Nakamura e Kataoka, 1999), mecanismo explorado neste trabalho.

O meio condicionado das culturas de microglia ativada pelo LPS foi analisado bioquimicamente antes da utilização dele nos neurônios motores. 
Interessantemente, mesmo antes da ativação com LPS, as microglias TG já secretavam quantidade maior de NO quando comparadas às WT. Xiao et al. (2007) mostraram que microglias provenientes de animais SOD1 ${ }^{\text {G93A }}$ são de fato mais responsivas ao estímulo pelo LPS, porém não demonstraram in vitro que essas já secretam mais NO que as WT antes mesmo da ativação. Estes resultados indicam que a microglia TG apresenta ativação intrínseca que a torna capaz de secretar substâncias citotóxicas com potencial neurodegenerativo.

A análise das quantificações dos prolongamentos neuronais das culturas WT e TG tratadas com os meios condicionados microgliais após a ativação com LPS mostrou a ausência de evidências da citotoxicidade dos meios condicionados microgliais TG. Notavelmente, os prolongamentos neuronais das culturas tratadas com microglias WT P60 são maiores quando comparados com aqueles tratados com meio condicionado proveniente de microglia TG ou até mesmo com meio neuronal. Recentemente, Sargsyan et al. (2011) mostraram que as microglias TG possuem deficiência da proteína integrina, esta envolvida em funções celulares diversas, tais como, adesão celular, migração e regulação do ciclo celular (Brakebusch et al., 2005). Níveis reduzidos de integrina podem prejudicar a adesão, a fagocitose e até mesmo a proliferação microglial. Nesse sentido, a presença do gene SOD1m na microglia pode estar prejudicando seu papel neurotrófico. Kawamura et al. (2012) mostraram a diminuição da imunoreatividade do IGF nas microglias próximas aos neurônios motores em degeneração na medula espinal de camundongos SOD $1^{\text {G93A }}$ logo que os primeiros sintomas aparecem, sugerindo a diminuição do potencial neurotrófico das microglias TG. Tal evento poderia, de fato facilitar a morte neuronal. Ainda não se sabe até que ponto a presença do gene SOD1m na microglia prejudica a secreção de fatores tróficos ao neurônio, porém o que pudemos concluir ao analisar nossos resultados foi que a microglia perdeu sua capacidade neuroprotetora, já que os prolongamentos neuronais obtidos após o tratamento com meio da microglia WT P60 eram maiores do que aqueles tratados com qualquer outro 
meio experimental. Mesmo assim, aqueles prolongamentos quantificados nos neurônios tratados com meios condicionados de microglia TG não se mostraram diminuídos quando comparados aos WT em ambas idades.

A análise da morte do neurônio motor foi avaliada in vitro pela marcação com o FluoroJade $\mathrm{C}$, utilizado na identificação das degenerações celulares e histológicas neuronais (Schmuck e Kahl, 2009). Como a morte neuronal pode ocorrer por apoptose ou necrose, um marcador capaz de identifica-la de modo não específico foi utilizado, diferentemente, por exemplo, do anticorpo BAX, marcador específico de apoptose, amplamente empregado na análise da influência das células gliais sobre a morte do neurônio motor na ELA (Nagai et al., 2007).

Aumento da morte neuronal não foi observada nos experimentos com meios condicionados microgliais após a ativação com LPS, sugerindo que a ativação microglial aplicada não foi capaz de promover a morte neuronal através de seus fatores secretados no meio, ou, possivelmente que a microglia não atua diretamente sobre a morte neuronal $e$, talvez, indiretamente como, por exemplo, através da secreção de fatores inflamatórios que por sua vez, ativam astrócitos e outras células gliais envolvidas que podem estar agindo diretamente na morte neuronal (Nagai et al., 2007).

\subsection{Análise da morte neuronal em co-culturas neurônio/microglia}

Com o objetivo de testar se o contato entre o neurônio e a microglia é capaz de promover a morte neuronal observada in vivo, experimentos de coculturas com as diferentes combinações genotípicas foram realizados. $O$ uso de co-culturas entre neurônios motores e células gliais permitem 0 detalhamento do papel dessas células na ELA (Gong et al., 2000; Pramatarova et al., 2001; Lino et al., 2002; Boillee et al., 2006; Nagai et al.,2007; Yamanaka et al., 2008). Este procedimento permite a comparação da influência do gene da SOD1m na microglia sobre neurônios e vice-versa. 
Quantidade maior de morte neuronal foi observada naquelas culturas neuronais co-cultivadas com microglias TG, em comparação aos neurônios na presença de microglias WT obtidas tanto do animal P1 quanto P60. A secreção de moléculas citotóxicas pela microglia TG como o NO, o NOX2 e a SOD extracelular (Weydt et al., 2004; Zhao et al., 2010; Liao et al., 2012) pode estar envolvida na morte dos neurônios motores. Além disso, a microglia TG madura secreta quantidade menor de BDNF, fato também relacionado à morte neuronal (Liao et al., 2012). Esses resultados corroboram com aqueles de Xiao et al. (2007) que demonstraram índice maior de morte do neurônio motor co-cultivado com a microglia TG P8 comparado à microglia WT. O diferencial do presente estudo foi o sistema de co-cultura sem pré-ativação microglial, levando à conclusão de que a presença do neurônio já ativa a microglia. Possivelmente, ainda, a comunicação direta entre as células pode aumentar o contato dos neurônios com as moléculas secretadas microgliais intensificando a morte.

\subsection{Quantificação das moléculas candidatas no meio condicionado microglial através da técnica de ELISA}

O presente estudo avaliou ainda a presença de moléculas específicas no meio condicionado de microglia ativada para o melhor entendimento do papel destas células na ELA. Moléculas que tiveram suas vias de secreção evidenciadas por genes diferencialmente expressos no microarray de medula espinal de camundongos TG com 40 e 80 dias de idade foram selecionadas (Anexo B).

As microglias são as principais produtoras e mais responsivas ao TNFa no SNC (Weydt et al., 2004). A sinalização do TNFa pode resultar em respostas inflamatórias, proliferação glial, migração celular, apoptose e necrose, dependendo do receptor e vias de sinalização ativada (McCoy e Tansey, 2008). Em condições patológicas, as microglias rapidamente se proliferam e tornam-se reativas, secretando grande quantidade de TNFa, uma citocina pró inflamatória com ações classicamente descritas (Bezzi et al., 2001). O nível aumentado de TNFa pela microglia pode agir diretamente 
sobre a liberação de glutamato pelo astrócito, influenciando deste modo na excitabilidade neuronal (Bezzi et al., 2001). Ainda, esta citocina em níveis aumentados pode agir diretamente sob os neurônios, já que seu receptor de afinidade primária, o TNFR1, é homólogo ao p75 e sua sinalização aumenta a excitabilidade neuronal com ação nas sinapses glutamatérgicas (Akassoglou et al., 2008; Balosso et al., 2005). Normalmente, a microglia secreta TNFa através da ativação da via da ERK após estímulos de ATP neuronais ou astrocitários (Suzuki et al., 2004). Em conjunto, o TNFa pode ser um fator microglial importante na ELA. Ressalta-se que o aumento dos níveis de TNFa no líquor e no soro de pacientes com ELA já foi demonstrado, aumentando com a progressão da doença (Moreau et al., 2005; Cereda et al., 2008). Os níveis de seus receptores solúveis também foram encontrados aumentados no soro desses pacientes (Moreau et al., 2005). O aumento da imunoreatividade principalmente em células microgliais e neurônios motores do RNAm de TNFa na medula espinal de camundongos SOD1 ${ }^{\mathrm{G} 93 \mathrm{~A}}$ foi observado inclusive antes do aparecimento dos primeiros sintomas (Elliott et al., 2001). Esse nível vai aumentando com a idade e atinge o pico na última fase da doença (Yoshihara et al., 2002). Os níveis do TNFR1 e TNFR2 nos neurônios motores e microglia aumentam concomitantemente com o aparecimento dos sintomas e se correlacionam com a severidade da doença (Elliott et al., 2001; Veglianese et al., 2006). Com essas evidências, Gowing et al. (2006) produziram um camundongo SOD $1{ }^{\text {G93A }}$ e knockout para TNFa porém, não observaram efeitos no que diz respeito ao início, severidade e progressão da doença, sugerindo que esse fator por si não é um contribuidor crucial para o desenvolvimento da doença (Gowing et al., 2006). Este trabalho mostra o aumento na produção de TNFa no meio condicionado das microglias TG P60 em relação às WT da mesma idade, o que corrobora com o trabalhode Weydt et al. (2004) que mostrou essa citocina no MC de microglias TG P60 após estímulo com LPS. Quando comparado, tal aumento não ocorre no meio condicionado das microglias cultivadas a partir da medula espinal do camundongo TG P1, o que indica que a microglia TG P60 já possui algum tipo de estímulo que a faz secretar 
quantidades alteradas de TNFa comparativamente àquelas WT em uma idade mais avançada do desenvolvimento, pouco antes do aparecimento dos sintomas.

A IL-6 é a citocina com mais abundância no SNC saudável, nessa situação sua função pode ser induzida pela atividade neuronal (Salman et al., 2000) e está relacionada com a diferenciação neuronal, crescimento axonal e estímulo da produção de NGF (Erta et al., 2012). Camundongos knockout para IL-6 têm deficiência no aprendizado e memória (Balschun et al., 2004). Apesar disso, a IL-6 tem participação ativa na neuroinflamação, transformando a resposta imune inata pela adquirida, aumentando a astrogliose, o stress oxidativo e a resposta inflamatória (Jones, 2005). A IL-6 modula a expressão de vários genes envolvidos na inflamação e na apoptose, dessa forma, encontrando-se aumentada em modelos de lesão do SNC (Erta et al., 2012). Nesses casos, essa citocina media a morte neuronal induzida por glutamato (Suzuki et al., 2000). Assim, a IL-6 também já foi identificada contribuindo para patologias do SNC (Campbell et al., 1993). No caso da ELA, foi observado o aumento da IL-6 no líquor (Terenghi et al., 2006), no soro (Moreau et al., 2005) e na pele (Ono et al., 2001) de pacientes e na medula espinal de camundongos SOD1 ${ }^{\mathrm{G} 93 \mathrm{~A}}$ (Moreau et al., 2005). Devido a pouca quantidade de estudos sobre a IL-6 no contexto da ELA, investigamos a sua quantidade no meio condicionado microglial e, de fato, pode-se observar que existe um aumento da secreção de IL-6 pelas microglias TG P60 comparadas às WT da mesma idade, indicando um mecanismo inflamatório por essas células. De fato, a média de IL-6 secretada por culturas de microglias puras após ativação de LPS é em torno de $60 \mathrm{pg} / \mathrm{ml}$ (Folden e Combs, 2007), o que corrobora com nossos resultados e evidencia a possibilidade microglia TG P60 envolver-se em respostas pró inflamatórias em grau maior em relação às WT. Weydt et al. (2004) demonstraram a diminuição da secreção de IL-6 pelas microglias TG P60 in vitro e postularam que a interação astrócito/microglia mediada pelo TNFa regula a expressão de IL-6 no sistema nervoso com ELA. No entanto, esses autores não decreveram dados de pureza da cultura microglial e nem 
fizeram a dosagem em culturas de astrócitos TG para o detalhamento do achado.

A falta de fatores neurotróficos contribuindo para doenças do neurônio motor é bem descrita (Appel et al., 1981). O IGF é um fator de crescimento que pode agir durante 0 desenvolvimento e na neurodegeneração, fornecendo suporte trófico aos neurônios motores (Corbo et al., 2010). Nos fluidos biológicos, o IGF se liga a proteínas de alta afinidade conhecidas como IGF-binding proteins (IGFBP), que agem como transportadores de IGF, prolongando sua meia vida e modulando sua atividade (Bach et al., 2005). O IGF e as IGFBP podem atravessar a barreira hematoencefálica e captar o IGF do líqudo cérebroespinal (Carro et al., 2000). Alterações no metabolismo de IGF e IGFBP na ELA já foram descritas. Corbo et al. (2010) demontraram uma correlação entre o IGF livre e a maior severidade da doença, possivelmente como uma reação compensatória ao dano neuronal. Além disso, a excitotoxicidade e a inflamação são processos que influenciam na progressão da doença e também podem levar à resistência da resposta ao IGF (Venters et al., 1999; Garcia-Galloway et al., 2003), o que poderia acelerar a progressão da ELA (Wilczak et al., 2003). A diminuição das IGFBP também já foi demonstrada no soro e no líquor de pacientes com ELA (Corbo et al., 2010), corroborando com os resultados do microarray da medula espinal de camundongos TG de 80 dias, onde a expressão do gene IGFBP4 apresentou-se 1,64 vezes menor em relação aos WT. Além disso, a literatura aponta também para o aumento do receptor de IGF no músculo e nos neurônios motores da medula espinal pós mortem de pacientes e do camundongo com ELA (Wilczaket al., 2003; Chung et al., 2003; Lunetta et al., 2012). Esses achados nos levaram a investigação da secreção de IGF pelas microglias cultivadas. Kawamura et al. (2012) demostraram in vivo a menor expressão de IGF na microglia TG em relação à WT após axotomia do nervo hipoglosso lesado do camundongo modelo da ELA de 70 dias, evidenciando o potencial neuroprotetor diminuído destas células. Kihira et al. (2007) descreveram em material pós mortem da medula espinal de 
pacientes com ELA, a população de microglia neuroprotetora, que expressa IGF, e outra citotóxica, que não apresenta a imunoreatividade do fator. Os resultados in vitro do presente trabalho mostraram que não houve diferença entre a secreção de IGF pelos diferentes grupos microgliais estudados.

O VEGF é um fator crítico para o controle do crescimento e permeabilidade de vasos sanguíneos tanto no desenvolvimento normal quanto na resposta a mudanças metabólicas (Carmeliet, 2000). O VEGF está relacionado classicamente ao crescimento tumoral (Skene e Cleveland, 2001). Camundongos com deleção dos genes promotores de VEGF apresentam profundos déficits motores na idade adulta com degeneração dos neurônios motores e atrofia muscular, o que os tornou um modelo experimental adicional para ELA (Lambrechts et al., 2003). O tratamento de neurônios motores cultivados com VEGF aumenta a sobrevida neuronal (Skene e Cleveland, 2001). Adicionalmente, a expressão de VEGF está diminuída nos neurônios sobreviventes de pacientes com ELA (Brockington et al., 2006), assim como os seus níveis no soro desses pacientes (Lambrechts et al., 2003). Nesta linha, a administração de VEGF antes ou após o início dos sintomas da doença foi capaz de diminuir a excitotoxicidade, de atrasar a morte neuronal e prolongar a vida do animal (Van Damme, 2009; Tovar-y-Romo e Tapia, 2012). Por fim, o nosso laboratório observou a diminuição da expressão do VEGFA na medula espinal dos camundongos de 40 dias e do VEGFB em 80 dias, o que nos levou a quantificar o fator VEGF nos meios condicionados microgliais. Entretanto, a ausência de diferença estatística entre os grupos poderia diminuir a importância da microglia nos possíveis papeis do VEGF na ELA.

Como já comentado, a resposta inflamatória microglial é caracterizada não só pela secreção de fatores que mediam a neurotoxicidade, mas também pela liberação de moléculas que promovem o reparo do tecido e regeneração neuronal (Elkabes et al., 1996). Interessantemente, a expressão do receptor de tirosina quinase NTRK1 está diminuída 2,43 vezes nas análises de microarray em animais TG de 40 dias e a expressão do 
receptor p75 NGFR está aumentada em 1,72 vezes nesses animais. Ambos os genes codificam para diferentes receptores de NGF. Assim, a probabilidade do NGF ligar-se ao receptor p75 aumenta. A quantificação do NGF nos meios condicionados de microglias WT e TG mostrou diferenças entre microglias P1 e P60, assim o fator pode modular as ações tóxicas da microglia na ELA, sendo esta uma possibilidade descrita aqui originalmente.

Heese et al. (1998) mostraram que o tratamento com LPS aumentou os níveis de expressão de NGF nas microglias cultivadas. O NGF é uma neurotrofina que se liga ao receptor tirosina quinase que ativa a via da MAP quinase sinalizando para a regulação de crescimento e ciclo celular (Turner et al., 2004). Já foi relacionado que elevada concentração de NGF satura os receptores tirosina quinase e o NGF por sua vez vai se ligar ao seu receptor de afinidade secundária, p75 que por sua vez sinaliza diretamente para morte celular. Neurônios saudáveis adultos não expressam p75, porém passam a expressar após uma lesão no SNC. O tratamento com 100ng/ml de NGF em células neuronais ativou o receptor p 75 e provocou $40 \%$ de mais morte celular do que nas culturas controle ou aquelas tratadas com $0,01 \mathrm{ng} / \mathrm{ml}$ de NGF, no qual ativou apenas os receptores tirosina quinase (Turner et al., 2004). Tais achados mostram que baixos níveis de NGF ativam receptores que sinalizam para viabilidade celular enquanto altos níveis ativam o p75 resultando em morte celular.

O aumento de NGF foi descrito na medula espinal e em biópsias de músculos de pacientes com ELA (Anand et al.,1995; Stuerenburg and Kunze, 1998; Kust et al., 2002). O tratamento com antagonista do receptor p75 em culturas de células de camundongos SOD1 ${ }^{\mathrm{G} 93 \mathrm{~A}}$ bloqueou o efeito de morte neuronal, porém não mostrou efeitos estatísticamente diferentes quando reproduziu o experimento in vivo (Turner et al., 2004). Dessa forma, existem evidências que $O \mathrm{NGF}$ pode contribuir com 0 processo neurodegenerativo da ELA e a microglia particularmente merece uma atenção especial nesse processo. 
As endotelinas (ET) formam uma pequena família de peptídeos expressas no SNC saudável por células endoteliais (Yoshimoto et al., 1990; Tsang et al., 2001), neurônios (Lee et al., 1990) e astrócitos (MacCumber et al., 1990; Tsang et al., 2001) que mantêm a tônus vascular cerebral. Após lesão no SNC, as microglias passam a expressar ET-1 (Wu et al., 2006). Altos níveis de ET-1 podem induzir a ativação e proliferação de astrócitos (Sasaki et al., 1998) e a regulação da secreção de citocinas (Wu et al., 2009). A reatividade de ET-1 é aumentada nessas células após lesão isquêmica no SNC (Yamashita et al., 1994; Barone et al., 1995), indicando que as ET podem contribuir para a lesão cerebral limitando a vasodilatação em resposta a isquemia e iniciando a gliose e inflamação após o evento. Em experimentos realizados no nosso laboratório, o gene do receptor de ET-1 EDNRA foi encontrado aumentado em 2,26 vezes nas análises de microarray da medula espinal de camundongos TG de 40 dias comparados ao WT da mesma idade. Os níveis de ET-1 nos meios condicionados das microglias foram bem semelhantes entre os grupos e possivelmente não participam dos mecanismos microgliais na ELA.

\subsection{Quantificação da expressão gênica microglial através da técnica de PCR em tempo real}

Os dados do microarray da medula de animais WT e TG apontaram para outros genes potencialmente importantes nas investigações do papel da microglia na ELA (Anexo $C$ ) e a expressão gênica de microglias do modelo experimental da ELA ainda não foi profundamente explorada na literatura.

O AKAP13 foi selecionado por estar superexpresso na medula espinal de camundongos TG tanto de 40 quanto de 80 dias em relação aos WT mas, a expressão deste gene nas culturas microgliais provenientes de animais com 60 dias não se mostrou alterada. Há pouca informação na literatura sobre a expressão de $A K A P$ em microglia e macrófagos. O papel da AKAP13 está diretamente relacionado com inflamação. Receptores toll like (TLR) são reguladores essenciais da imunidade inata, iniciando uma cascata 
cumulativa na ativação do fator de transcrição do NF-Kß (Matsumoto et al., 2003). Estudos recentes têm mostrado que a $A K A P 13$, uma proteína quinase, é induzida por um TLR específico conhecido como TLR2 para ativar a via NF-K $\beta$ e direcionar o local e a resposta imunológica específica (Kim et al., 2011). Outra função conhecida da AKAP13 é de ser uma proteína que coordena a via da Rho (Diviani et al., 2011). Essa via é composta principalmente pelas moléculas Cdc42, Rac1 e RhoA. Tais moléculas participam da organização do citoesqueleto e da adesão célula/matriz extracelular (Jones et al., 2000), participando da mobilidade celular. Os presentes experimentos de PCR em tempo real mostraram que a AKAP13 está diminuída nas microglias TG neonatais em relação às WT. Considerando que a AKAP13 sinaliza a via da Rho que guia para mobilidade celular, poderíamos supor que as microglias TG podem apresentar um problema de mobilidade celular que as impede de fagocitar de modo eficaz neurônios em degeneração ou até de se dirigir ao sítio de lesão, perdendo a capacidade neuroprotetiva. Esses dados corroboram com 0 efeito encontrado na quantificação de prolongamentos neuronais. Recentemente Yan et al. (2012) mostraram que a microglia possui receptores de Nogo-66 ( $\mathrm{NgR})$ que ativam a via Rho e que guiam para a mobilidade microglial através da Cdc42. Camundongos knockout para $\mathrm{NgR}$ demonstram menor expressão de Cdc42 e menor aderência e migração microglial, indicando que a baixa expressão da $A K A P 13$ nas microglias TG $\mathrm{P} 1$ pode estar causando a não ativação da Rho e por consequência a não ativação da Cdc42 com consequente perda de mobilidade microglial.

O HIPK3 codifica a proteína de mesmo nome capaz de interagir com receptores de superfície e ao mesmo tempo ter funções nucleares importantes (Rochat-Steinr et al., 2000). A função clássica da HIPK3 é de fosforilar a FADD, uma proteína adaptadora do receptor de superfície da superfamília de TNF (Kretz-Remyet al., 1996, Rochat-Steiner et al., 2000). A alta expressão de HIPK3 em células cancerígenas resistentes à morte por diferentes drogas (Curtin e Cotter, 2004) permitiu o entendimento de seu 
funcionamento, no qual está envolvido com a regulação de apoptose através da regulação da fosforilação da FADD. Rochat-Steiner et al. (2000) identificaram uma nova proteína quinase de interação com a FADD chamada FIST/HIPK3 que impede a ativação JNK conferindo resistência à apoptose.

O PCR em tempo real para o gene HIPK3 nas microglias P1 apresentou diminuição da expressão gênica nas microglias TG em relação às WT. Dado que as microglias ao entrarem em processo de apoptose secretam mais fatores apoptóticos, tornando o ambiente em que se encontram tóxico aos neurônios, podemos postular que com a diminuição de HIPK3, as microglias TG não oferecem resistência a apoptose, entrando assim em um processo de morte crônico, tornando o ambiente tóxico e estimulando então morte neuronal através de fatores citotóxicos, evidenciando o papel da microglia na morte neuronal da ELA. O mesmo não ocorre nas microglias P60 onde não aparece diferença estatística da expressão de HIPK3 entre os grupos, mostrando que essa relação se estabiliza com o aumento da idade e progressão da doença.

O NKRF (NF-kß repressing factor) foi identificado como uma proteína

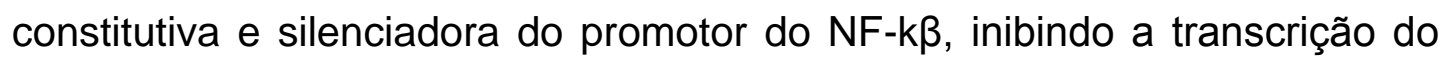
mesmo (Nourbakhsh e Hauser, 1999). Como já comentado acima, o NF-kß é essencial para a mediação de secreção de citocinas inflamatórias. Estudos mostram que 0 tratamento com anti-inflamatório em doenças neurodegenerativas como a esclerose múltipla aumentam os níveis nucleares de NKRF diminuindo por sua vez a inflamação através da menor ativação de astrócitos e microglias (Wilms et al., 2010). Crosio et al. (2011) inibiram a via NF-k $\beta$ seletivamente nos astrócitos de camundongos SOD1 ${ }^{\text {G93A }}$, porém não obtiveram benefícios no início e progressão da doença. Foi reportado através de imunohistoquímica maior ativação do NF$\mathrm{K} \beta$ em neurônios, astrócitos e microglias da medula espinal pós mortem de pacientes com ELA. Ainda não foi realizada a manipulação da via NF-K $\beta$ nessas três linhagens celulares concomitantemente no contexto da ELA. O autor sugere que esssa via tem um papel central na patologia da doença, 
envolvendo três importantes células do SNC e pode ser um bom alvo terapêutico (Sako et al., 2012). OPTN é um gene que codifica a optineurina e é responsável por ativar o fator NF-Kß bloqueando sua inibição. Muitos pacientes com ELA possuem mutação nesse gene e o camundongo TG com essa mutação desenvolve o fenótipo da ELA o que o tornou um modelo experimental aceito pela literatura atual (Maruyama et al., 2010). Não há trabalhos que descrevem a expressão dos níveis de NKRF em animais ou pacientes com ELA. Nas análises de microarray de medula espinal dos nossos animais com 80 dias a expressão deste gene está quase 5 vezes mais altanos animais TG do que nos WT. Os resultados na microglia mostram que não há diferença estatística entre os níveis de NKRF entre as microglias TG e WT de ambas as idades, mostrando que esse fator não está diminuído nos TG, ou seja, a inflamação presente na ELA não deve ocorrer devido à diminuição de NKRF nas microglias e sim por outros fatores ainda não descritos.

A modificação de proteínas SUMO (Small ubiquitin-like modifier) tem efeitos sobre a estabilidade, localização, interações proteína-proteína e regulamento transcricional (Kim et al., 2002; Seeler e Dejean, 2003; Johnson, 2004). Essa modificação SUMO é vista como uma pequena ubiquitinização levando a uma alteração na atividade proteica. A proteína Ube2i está envolvida nesse processo, atuando como uma enzima conjugadora de moléculas SUMO e promovendo a degradação protéica in vivo (Xu et al., 2009). O processo de sumoilação e degradação protéica é totalmente dependente da Ube2i (Sun et al., 2007; Uzunova et al., 2007). O gene UBE2I tem um papel importante na supressão ou promoção da proliferação de células (Qin et al., 2011). Pode-se observar que essas expressões de UBE2/ não seguem a mesma proporção nas microglias TG e WT, apresentando-se menor nas microglias TG P1, evidenciando uma desregulação na proliferação microglial. Essa diferença pode ser um indicativo da participação dessas células nos mecanismos da ELA, algo que deve ser explorado no futuro. 
O gene NTF5 codifica a proteína de mesmo nome, também conhecida como NT-4/5. Essa proteína foi recentemente identificada no Xenopus laevis com atividade neurotrófica capaz de promover o crescimento neurítico e sobrevivência neuronal (Hallbook et al., 1991). Camundongos knockout para NT-5 têm um desenvolvimento normal com perda de neurônios motores e sensoriais apenas na idade adulta (Conover e Yancopoulos, 1997). O tratamento de neurônios motores com NT-5 aumentou a sobrevivência e crescimento neurítico (Meyer-Franke et al.,1995). A NT-4/5 se liga ao receptor de baixa afinidade $p 75$ e ao receptor tirosina quinase B com alta especificidade (Klein et al., 1992). Culturas purificadas de microglias de córtex de camundongos neonatos não aumentam a expressão de NT-4/5 após a ativação com LPS, apesar de ter aumentado a expressão de NGF e BDNF, oque indica que o LPS regula diferencialmente essas neurotrofinas nas células microgliais (Elkabes et al, 1998). O tratamento com NT-4/5 em culturas microgliais aumentou sua proliferação sugerindo que ela pode produzir essa neurotrofina de uma forma autócrina ou parácrina (Elkabes et al., 1996; Scarisbrick et al., 2000). Duberley et al. (1997) não observaram diferenças de NT-4/5 em pacientes com ELA esporádica e controle através de imunohistoquímica de neurônios do córtex cerebral. Já em biópsias de músculo de pacientes com ELA foi observado o aumento de RNAm de NTF5 durante a progressão da doença (Kust et al., 2002). Em conjunto, podemos observar que existem indícios de que a baixa expressão de NTF5 precocemente em 40 dias poderia participar de alguma forma com a ELA. Com isso, foi quantificada a expressão gênica de NTF5 nas microglias cultivadas em ambas as idades. Interessantemente pode-se notar uma diminuição precoce dessa expressão nas microglias TG $\mathrm{P} 1$, o que poderia colaborar com a sinalização parácrina neuronal, diminuindo o suporte trófico microglial para esses neurônios, podendo ser uma nova indicação de alvo terapêutico.

Os resultados dos PCR em tempo real de um modo geral sugerem dados que apontam evidências precoces nas microglias P1. A ausência de evidências das microglias $P 60$ sugere que essas células podem ter perdido $O$ 
estímulo que tinham quando em contato com neurônios no modelo in vivo. Esse fato pode ter ocorrido já que essas células demoram mais para se adaptar e proliferar em ambiente de cultura quando comparadas aquelas cultivadas a partir da medula espinal de camundongos com 1 dia, o que atarsa o processo de purificação e estímulo com LPS. Esse tempo em cultura, que é em média de 6 semanas, pode ter estabilizado a microglia que por sua vez perdeu o estímulo do ambiente tóxico que se encontrava no animal e ganhou um ambiente totalmente controlado em condições normais de cultivo. Assim, o LPS pode não ter sido capaz de re-estimular essas células no ponto de vista de expressão de RNA.

De uma forma geral, as evidências desse estudo sugerem que o diálogo entre os neurônios motores e a microglia se inicia com perda de neuroproteção (Appel et al., 2011) com menor expressão de NTF5, menor capacidade de migração pela $A K A P 13$ e maior proliferaçao com diminuição de HIPK3. No entanto, esse resultado ainda não é capaz de refletir nos prolongamentos neuronais como foi visto nas quantificações do experimento do tratamento de meio condicionado. Com o aumento do estresse oxidativo e a presença da SOD1m nas células microgliais de animais adultos, essa neuroproteção é perdida e a microglia, por sua vez, para de produzir substâncias anti-inflamatórias e começa a secretar substâncias próinflamatórias como IL-6, TNFa e NGF em excesso, facilitando a morte neuronal.

Um melhor entendimento da sinalização bidirecional entre os neurônios motores e a microglia pode alcançar novas terapias para restaurar esse desequilíbrio entre a neuroproteção e a neurotoxicidade. Sendo assim, esse estudo esclarece um pouco melhor essa sinalização e aponta para possíveis novos alvos de estudo e até futuramente terapêuticos no contexto da ELA. 


\section{Conclusões}

- A obtenção de culturas purificadas de microglia retiradas da medula espinal de camundongos WT e TG pode contribuir para o estudo da fisiopatologia da ELA pela utilização delas em experimento in vitro.

- A microglia sem ativação do LPS não foi capaz de causar a diminuição nos prolongamentos neuronais de qualquer genótipo.

- Após a ativação com LPS, as microglias TG P60 não foram capazes de promover a arborização neuronal observada nos neurônios tratados com meio condicionado de microglia WT P60.

- O tratamento com meio condicionado microglial após a ativação com LPS não foi capaz de promover a morte neuronal.

- Em co-cultura, as microglias TG (P1 e P60) promoveram maior morte aos neurônios WT evento não observado para os neurônios TG.

- A citotoxicidade da microglia TG ao neurônio motor na ELA pode estar relacionada ao aumento da secreção de moléculas como TNFa, IL-6 e NGF, porém os mecanismos relacionados aindam precisam ser elucidados.

- O estudo da expressão gênica nas culturas de microglia provenientes de camundongos SOD1 ${ }^{\mathrm{G} 93 \mathrm{~A}}$ mostrou que, se expandido, pode trazer subsídios adicionais sobre os mecanismos da participação da microglia na ELA. 


\section{Referências Bibliográficas}

Akassoglou K, Probert L, Kontogeorgos G, Kollias G. Astrocyte-specific but not neuron-specific transmembrane TNF triggers inflammation and degeneration in the central nervous system of transgenic mice. $J$ Immunol. 1997 Jan 1;158(1):438-45.

Alexianu ME, Kozovska M, Appel SH. Immune reactivity in a mouse model of familial ALS correlates with disease progression. Neurology. 2001 Oct 9;57(7):1282-9.

Almer G, Teismann P, Stevic Z, Halaschek-Wiener J, Deecke L, Kostic V, et al. Increased levels of the pro-inflammatory prostaglandin PGE2 in CSF from ALS patients. Neurology. 2002 Apr 23;58(8):1277-9.

Alves CJ, de Santana LP, dos Santos AJ, de Oliveira GP, Duobles T, Scorisa $\mathrm{JM}$, et al. Early motor and electrophysiological changes in transgenic mouse model of amyotrophic lateral sclerosis and gender differences on clinical outcome. Brain Res. 2011 Jun 7;1394:90-104.

Anand P, Parrett A, Martin J, Zeman S, Foley P, Swash M, et al. Regional changes of ciliary neurotrophic factor and nerve growth factor levels in post mortem spinal cord and cerebral cortex from patients with motor disease. Nat Med. 1995 Feb;1(2):168-72.

Anderson KN, Potter AC, Piccenna LG, Quah AK, Davies KE, Cheema SS. Isolation and culture of motor neurons from the newborn mouse spinal cord. Brain Res Brain Res Protoc. 2004 Feb;12(3):132-6.

Appel SH. A unifying hypothesis for the cause of amyotrophic lateral sclerosis, parkinsonism, and Alzheimer disease. Ann Neurol. 1981 Dec;10(6):499-505.

Appel SH, Stewart SS, Appel V, Harati Y, Mietlowski W, Weiss W, et al.A double-blind study of the effectiveness of cyclosporine in amyotrophic lateral sclerosis.Archives of neurology. 1988 Apr;45(4):381-6.

Appel SH, Zhao W, Beers DR, Henkel JS.The microglial-motoneuron dialogue in ALS.Acta Myol. 2011 Jun;30(1):4-8.

Arai T, Hasegawa M, Akiyama $\mathrm{H}$, Ikeda $\mathrm{K}$, Nonaka T, Mori $\mathrm{H}$, et al. TDP-43 is a component of ubiquitin-positive tau-negative inclusions in frontotemporal lobar degeneration and amyotrophic lateral sclerosis. Biochem Biophys Res Commun. 2006 Dec 22;351(3):602-11. 
Bach LA, Headey SJ, Norton RS. IGF-binding proteins--the pieces are falling into place. Trends Endocrinol Metab. 2005 Jul;16(5):228-34.

Balosso S, Ravizza T, Perego C, Peschon J, Campbell IL, De Simoni MG, et al. Tumor necrosis factor-alpha inhibits seizures in mice via p75 receptors. Ann Neurol. 2005 Jun;57(6):804-12.

Banfield MJ, Naylor RL, Robertson AG, Allen SJ, Dawbarn D, Brady RL. Specificity in Trk receptor:neurotrophin interactions: the crystal structure of TrkB-d5 in complex with neurotrophin-4/5. Structure. 2001 Dec;9(12):1191-9.

Barnes K, Turner AJ. The endothelin system and endothelin-converting enzyme in the brain: molecular and cellular studies. Neurochem Res. 1997 Aug;22(8):1033-40.

Barone FC, Willette RN, Yue TL, Feurestein G. Therapeutic effects of endothelin receptor antagonists in stroke. Neurol Res. 1995 Aug;17(4):259-64.

Beers DR, Henkel JS, Xiao Q, Zhao W, Wang J, Yen AA, et al. Wild-type microglia extend survival in PU.1 knockout mice with familial amyotrophic lateral sclerosis. Proc Natl Acad Sci U S A. 2006 Oct 24;103(43):16021-6.

Beilharz EJ, Russo VC, Butler G, Baker NL, Connor B, Sirimanne ES, et al. Co-ordinated and cellular specific induction of the components of the IGF/IGFBP axis in the rat brain following hypoxic-ischemic injury. Brain Res Mol Brain Res. 1998 Aug 31;59(2):119-34.

Bellini MJ, Herenu CB, Goya RG, Garcia-Segura LM.Insulin-like growth factor-I gene delivery to astrocytes reduces their inflammatory response to lipopolysaccharide. J Neuroinflammation. 2011;8:21.

Bendotti C, Carri MT. Lessons from models of SOD1-linked familial ALS. Trends Mol Med. 2004 Aug;10(8):393-400.

Bezzi P, Domercq M, Brambilla L, Galli R, Schols D, De Clercq E, et al. CXCR4-activated astrocyte glutamate release via TNFalpha: amplification by microglia triggers neurotoxicity. Nat Neurosci. 2001 Jul;4(7):702-10.

Block ML, Hong JS. Microglia and inflammation-mediated neurodegeneration: multiple triggers with a common mechanism. Prog Neurobiol. 2005 Jun;76(2):77-98.

Boer K, Troost D, Spliet WG, van Rijen PC, Gorter JA, Aronica E. Cellular distribution of vascular endothelial growth factor $A$ (VEGFA) and $B$ 
(VEGFB) and VEGF receptors 1 and 2 in focal cortical dysplasia type IIB. Acta Neuropathol. 2008 Jun;115(6):683-96.

Boillee S, Vande Velde C, Cleveland DW. ALS: a disease of motor neurons and their nonneuronal neighbors. Neuron. 2006 Oct 5;52(1):39-59.

Brakebusch $\mathrm{C}$, Fassler $\mathrm{R}$. beta 1 integrin function in vivo: adhesion, migration and more. Cancer Metastasis Rev. 2005 Sep;24(3):403-11.

Brentani RR, Carraro DM, Verjovski-Almeida S, Reis EM, Neves EJ, de Souza SJ, et al. Gene expression arrays in cancer research: methods and applications. Crit Rev Oncol Hematol. 2005 May;54(2):95-105.

Brockington A, Wharton SB, Fernando M, Gelsthorpe CH, Baxter L, Ince PG, et al. Expression of vascular endothelial growth factor and its receptors in the central nervous system in amyotrophic lateral sclerosis. J Neuropathol Exp Neurol. 2006 Jan;65(1):26-36.

Browne SE, Yang L, DiMauro JP, Fuller SW, Licata SC, Beal MF. Bioenergetic abnormalities in discrete cerebral motor pathways presage spinal cord pathology in the G93A SOD1 mouse model of ALS. Neurobiol Dis. 2006 Jun;22(3):599-610.

Bruijn LI, Becher MW, Lee MK, Anderson KL, Jenkins NA, Copeland NG, et al. ALS-linked SOD1 mutant G85R mediates damage to astrocytes and promotes rapidly progressive disease with SOD1-containing inclusions. Neuron. 1997 Feb;18(2):327-38.

Bruijn LI, Miller TM, Cleveland DW. Unraveling the mechanisms involved in motor neuron degeneration in ALS. Annu Rev Neurosci. 2004;27:72349.

Brustle A, Heink S, Huber M, Rosenplanter C, Stadelmann C, Yu P, et al. The development of inflammatory $\mathrm{T}(\mathrm{H})-17$ cells requires interferonregulatory factor 4. Nat Immunol. 2007 Sep;8(9):958-66.

Carmeliet P. VEGF gene therapy: stimulating angiogenesis or angiomagenesis? Nat Med. 2000 Oct;6(10):1102-3.

Carro E, Nunez A, Busiguina S, Torres-Aleman I. Circulating insulin-like growth factor I mediates effects of exercise on the brain. J Neurosci. 2000 Apr 15;20(8):2926-33.

Cereda C, Baiocchi C, Bongioanni P, Cova E, Guareschi S, Metelli MR, et al. TNF and sTNFR1/2 plasma levels in ALS patients. Journal of neuroimmunology. 2008 Feb;194(1-2):123-31. 
Cernak I, Stoica B, Byrnes KR, Di Giovanni S, Faden Al. Role of the cell cycle in the pathobiology of central nervous system trauma. Cell cycle (Georgetown, Tex. 2005 Sep;4(9):1286-93.

Chao CC, Hu S, Molitor TW, Shaskan EG, Peterson PK. Activated microglia mediate neuronal cell injury via a nitric oxide mechanism.J Immunol. 1992 Oct 15;149(8):2736-41.

Chung MJ, Suh YL. Ultrastructural changes of mitochondria in the skeletal muscle of patients with amyotrophic lateral sclerosis. Ultrastruct Pathol. 2002 Jan-Feb;26(1):3-7.

Chung $\mathrm{YH}$, Joo KM, Shin $\mathrm{CM}$, Lee $\mathrm{YJ}$, Shin $\mathrm{DH}$, Lee $\mathrm{KH}$, et al. Immunohistochemical study on the distribution of insulin-like growth factor I (IGF-I) receptor in the central nervous system of SOD1(G93A) mutant transgenic mice. Brain Res. 2003 Dec 24;994(2):253-9.

Clement AM, Nguyen MD, Roberts EA, Garcia ML, Boillee S, Rule M, et al. Wild-type nonneuronal cells extend survival of SOD1 mutant motor neurons in ALS mice. Science. 2003 Oct 3;302(5642):113-7.

Colafrancesco V, Villoslada P. Targeting NGF pathway for developing neuroprotective therapies for multiple sclerosis and other neurological diseases. Arch Ital Biol. 2011 Jun;149(2):183-92.

Conlon I, Raff M. Size control in animal development.Cell. 1999 Jan 22;96(2):235-44.

Conover JC, Yancopoulos GD. Neurotrophin regulation of the developing nervous system: analyses of knockout mice. Rev Neurosci. 1997 JanMar;8(1):13-27.

Corbo M, Lunetta C, Magni P, Dozio E, Ruscica M, Adobbati L, et al. Free insulin-like growth factor (IGF)-1 and IGF-binding proteins-2 and -3 in serum and cerebrospinal fluid of amyotrophic lateral sclerosis patients. Eur J Neurol. 2010 Mar;17(3):398-404.

Crosio C, Valle C, Casciati A, laccarino C, Carri MT. Astroglial inhibition of NF-kappaB does not ameliorate disease onset and progression in a mouse model for amyotrophic lateral sclerosis (ALS). PLoS One. 2011;6(3):e17187.

Cudkowicz ME, Shefner JM, Schoenfeld DA, Zhang H, Andreasson KI, Rothstein JD, et al. Trial of celecoxib in amyotrophic lateral sclerosis. Ann Neurol. 2006 Jul;60(1):22-31. 
Curtin JF, Cotter TG. JNK regulates HIPK3 expression and promotes resistance to Fas-mediated apoptosis in DU 145 prostate carcinoma cells. J Biol Chem. 2004 Apr 23;279(17):17090-100.

Das KP, McMillian MK, Bing G, Hong JS. Modulatory effects of [Met5]enkephalin on interleukin-1 beta secretion from microglia in mixed brain cell cultures. Journal of neuroimmunology. 1995 Oct;62(1):9-17.

De Vos KJ, Chapman AL, Tennant ME, Manser C, Tudor EL, Lau KF, et al. Familial amyotrophic lateral sclerosis-linked SOD1 mutants perturb fast axonal transport to reduce axonal mitochondria content. Hum Mol Genet. 2007 Nov 15;16(22):2720-8.

DeJesus-Hernandez M, Mackenzie IR, Boeve BF, Boxer AL, Baker M, Rutherford $\mathrm{NJ}$, et al. Expanded GGGGCC hexanucleotide repeat in noncoding region of C9ORF72 causes chromosome 9p-linked FTD and ALS. Neuron. 2011 Oct 20;72(2):245-56.

Dibaj P, Steffens H, Zschuntzsch J, Kirchhoff F, Schomburg ED, Neusch C. In vivo imaging reveals rapid morphological reactions of astrocytes towards focal lesions in an ALS mouse model. Neuroscience letters. 2011 Jun 22;497(2):148-51.

Diviani D, Dodge-Kafka KL, Li J, Kapiloff MS. A-kinase anchoring proteins: scaffolding proteins in the heart. Am J Physiol Heart Circ Physiol. 2011 Nov;301(5):H1742-53.

Drachman DB, Frank K, Dykes-Hoberg M, Teismann P, Almer G, Przedborski $S$, et al. Cyclooxygenase 2 inhibition protects motor neurons and prolongs survival in a transgenic mouse model of ALS. Ann Neurol. 2002 Dec;52(6):771-8.

Droppelmann CA, Keller BA, Campos-Melo D, Volkening K, Strong MJ. Rho guanine nucleotide exchange factor is an NFL mRNA destabilizing factor that forms cytoplasmic inclusions in amyotrophic lateral sclerosis. Neurobiol Aging. 2013 Jan;34(1):248-62.

Duberley RM, Johnson IP, Anand P, Leigh PN, Cairns NJ. Immunocytochemical studies of neurotrophins in cerebral motor cortex in Amyotrophic Lateral Sclerosis. Brain Res. 1997 Jul 25;763(2):25963.

Duobles T, Lima Tde S, Levy Bde F, Chadi G. S100beta and fibroblast growth factor-2 are present in cultured Schwann cells and may exert paracrine actions on the peripheral nerve injury. Acta Cir Bras. 2008 Nov-Dec;23(6):555-60. 
Ekegren T, Grundstrom E, Lindholm D, Aquilonius SM. Upregulation of Bax protein and increased DNA degradation in ALS spinal cord motor neurons. Acta Neurol Scand. 1999 Nov;100(5):317-21.

Elkabes S, DiCicco-Bloom EM, Black IB. Brain microglia/macrophages express neurotrophins that selectively regulate microglial proliferation and function. J Neurosci. 1996 Apr 15;16(8):2508-21

Elkabes S, Peng L, Black IB. Lipopolysaccharide differentially regulates microglial trk receptor and neurotrophin expression. J Neurosci Res. 1998 Oct 1;54(1):117-22.

Elliott JL. Cytokine upregulation in a murine model of familial amyotrophic lateral sclerosis. Brain Res Mol Brain Res. 2001 Nov 1;95(1-2):172-8.

Erta M, Quintana A, Hidalgo J. Interleukin-6, a major cytokine in the central nervous system. Int J Biol Sci. 2012;8(9):1254-66.

Ezzi SA, Urushitani M, Julien JP. Wild-type superoxide dismutase acquires binding and toxic properties of ALS-linked mutant forms through oxidation. J Neurochem. 2007 Jul;102(1):170-8.

Fellin T, Sul JY, D'Ascenzo M, Takano $H$, Pascual O, Haydon PG. Bidirectional astrocyte-neuron communication: the many roles of glutamate and ATP. Novartis Found Symp. 2006;276:208-17; discussion 17-21, 33-7, 75-81.

Feng X, Guo Z, Nourbakhsh M, Hauser H, Ganster R, Shao L, et al. Identification of a negative response element in the human inducible nitric-oxide synthase (hiNOS) promoter: The role of NF-kappa Brepressing factor (NRF) in basal repression of the hiNOS gene. Proc Natl Acad Sci U S A. 2002 Oct 29;99(22):14212-7.

Ferraiuolo L, Kirby J, Grierson AJ, Sendtner M, Shaw PJ. Molecular pathways of motor neuron injury in amyotrophic lateral sclerosis. Nat Rev Neurol. 2011 Nov;7(11):616-30.

Ferri A, Cozzolino M, Crosio C, Nencini M, Casciati A, Gralla EB, et al. Familial ALS-superoxide dismutases associate with mitochondria and shift their redox potentials. Proc Natl Acad Sci U S A. 2006 Sep 12;103(37):13860-5.

Filipovich T, Fleisher-Berkovich S. Regulation of glial inflammatory mediators synthesis: possible role of endothelins. Peptides. 2008 Dec;29(12):2250-6. 
Floden AM, Combs CK. Microglia repetitively isolated from in vitro mixed glial cultures retain their initial phenotype. Journal of neuroscience methods. 2007 Aug 30;164(2):218-24.

Friedlander RM, Brown RH, Gagliardini V, Wang J, Yuan J. Inhibition of ICE slows ALS in mice. Nature. 1997 Jul 3;388(6637):31.

Fukushima A, Sumi T, Ishida W, Yamada J, Iwakura Y, Ueno H. Endogenous IL-17 does not play a significant role in the development of experimental murine allergic conjunctivitis. Int Arch Allergy Immunol. 2008;147(3):206-12.

Garcia-Galloway E, Arango C, Pons S, Torres-Aleman I. Glutamate excitotoxicity attenuates insulin-like growth factor-I prosurvival signaling. Mol Cell Neurosci. 2003 Dec;24(4):1027-37.

Gehrmann J, Matsumoto Y, Kreutzberg GW. Microglia: intrinsic immuneffector cell of the brain. Brain Res Brain Res Rev. 1995 Mar;20(3):269-87

Gomide VC, Chadi G. The trophic factors S-100beta and basic fibroblast growth factor are increased in the forebrain reactive astrocytes of adult callosotomized rat. Brain Res. 1999 Jul 24;835(2):162-74.

Gong YH, Parsadanian AS, Andreeva A, Snider WD, Elliott JL. Restricted expression of G86R Cu/Zn superoxide dismutase in astrocytes results in astrocytosis but does not cause motoneuron degeneration. J Neurosci. 2000 Jan 15;20(2):660-5.

Gordon PH, Moore DH, Miller RG, Florence JM, Verheijde JL, Doorish C, et al. Efficacy of minocycline in patients with amyotrophic lateral sclerosis: a phase III randomised trial. Lancet neurology. 2007 Dec;6(12):1045-53.

Gowing G, Dequen F, Soucy G, Julien JP. Absence of tumor necrosis factoralpha does not affect motor neuron disease caused by superoxide dismutase 1 mutations. J Neurosci. 2006 Nov 1;26(44):11397-402.

Graber DJ, Hickey WF, Harris BT. Progressive changes in microglia and macrophages in spinal cord and peripheral nerve in the transgenic rat model of amyotrophic lateral sclerosis.J Neuroinflammation. Jan 28;7(1):8.

Gudi V, Skuljec J, Yildiz O, Frichert K, Skripuletz T, Moharregh-Khiabani D, et al. Spatial and temporal profiles of growth factor expression during CNS demyelination reveal the dynamics of repair priming. PLoS One. 2011;6(7):e22623. 
Guegan C, Vila M, Rosoklija G, Hays AP, Przedborski S. Recruitment of the mitochondrial-dependent apoptotic pathway in amyotrophic lateral sclerosis. J Neurosci. 2001 Sep 1;21(17):6569-76.

Gunther A, Kuppers-Tiedt L, Schneider PM, Kunert I, Berrouschot J, Schneider D, et al. Reduced infarct volume and differential effects on glial cell activation after hyperbaric oxygen treatment in rat permanent focal cerebral ischaemia. The European journal of neuroscience. 2005 Jun;21(11):3189-94.

Gurney ME, Pu H, Chiu AY, Dal Canto MC, Polchow CY, Alexander DD, et al. Motor neuron degeneration in mice that express a human $\mathrm{Cu}, \mathrm{Zn}$ superoxide dismutase mutation. Science. 1994 Jun 17;264(5166):1772-5.

Hall ED, Oostveen JA, Gurney ME. Relationship of microglial and astrocytic activation to disease onset and progression in a transgenic model of familial ALS.Glia. $1998 \mathrm{Jul} ; 23(3): 249-56$.

Hallbook F, Ibanez CF, Persson $\mathrm{H}$. Evolutionary studies of the nerve growth factor family reveal a novel member abundantly expressed in Xenopus ovary. Neuron. 1991 May;6(5):845-58.

Hanisch UK. Microglia as a source and target of cytokines.Glia. 2002 Nov;40(2):140-55.

Hanisch UK, Kettenmann $\mathrm{H}$. Microglia: active sensor and versatile effector cells in the normal and pathologic brain. Nat Neurosci. 2007 Nov;10(11):1387-94

Haydon PG. GLIA: listening and talking to the synapse. Nat Rev Neurosci. $2001 \mathrm{Mar} ; 2(3): 185-93$.

Haydon PG, Carmignoto G. Astrocyte control of synaptic transmission and neurovascular coupling. Physiol Rev. 2006 Jul;86(3):1009-31.

He BP, Wen W, Strong MJ.Activated microglia (BV-2) facilitation of TNFalpha-mediated motor neuron death in vitro.Journal of neuroimmunology. 2002 Jul;128(1-2):31-8.

Heese K, Hock C, Otten U. Inflammatory signals induce neurotrophin expression in human microglial cells. J Neurochem. 1998 Feb;70(2):699-707.

Henderson CE, Bloch-Gallego E, Camu W. Purified embryonic motorneurons. In: Cohen, J.; Wilkin, G.P. Neural Cell Culture. A pratical approach. Londres: ILR Press; 2002. 69-81. 
Henkel JS, Beers DR, Siklos L, Appel SH. The chemokine MCP-1 and the dendritic and myeloid cells it attracts are increased in the mSOD1 mouse model of ALS. Mol Cell Neurosci. 2006 Mar;31(3):427-37.

Henkel JS, Beers DR, Zhao W, Appel SH. Microglia in ALS: the good, the bad, and the resting. J Neuroimmune Pharmacol. 2009 Dec;4(4):38998.

Henkel JS, Engelhardt JI, Siklos L, Simpson EP, Kim SH, Pan T, et al. Presence of dendritic cells, MCP-1, and activated microglia/macrophages in amyotrophic lateral sclerosis spinal cord tissue. Ann Neurol. 2004 Feb;55(2):221-35.

Hensley K, Abdel-Moaty H, Hunter J, Mhatre M, Mou S, Nguyen K, et al. Primary glia expressing the G93A-SOD1 mutation present a neuroinflammatory phenotype and provide a cellular system for studies of glial inflammation. J Neuroinflammation. 2006;3:2.

Higgins CM, Jung C, Xu Z. ALS-associated mutant SOD1G93A causes mitochondrial vacuolation by expansion of the intermembrane space and by involvement of SOD1 aggregation and peroxisomes. BMC Neurosci. 2003 Jul 15;4:16.

Howland DS, Liu J, She Y, Goad B, Maragakis NJ, Kim B, et al. Focal loss of the glutamate transporter EAAT2 in a transgenic rat model of SOD1 mutant-mediated amyotrophic lateral sclerosis (ALS). Proc Natl Acad Sci U S A. 2002 Feb 5;99(3):1604-9.

Ignarro LJ, Byrns RE, Buga GM, Wood KS. Endothelium-derived relaxing factor from pulmonary artery and vein possesses pharmacologic and chemical properties identical to those of nitric oxide radical. Circ Res. 1987 Dec;61(6):866-79.

llieva $H$, Polymenidou M, Cleveland DW. Non-cell autonomous toxicity in neurodegenerative disorders: ALS and beyond. J Cell Biol. 2009 Dec 14;187(6):761-72.

Ince PG, Tomkins J, Slade JY, Thatcher NM, Shaw PJ. Amyotrophic lateral sclerosis associated with genetic abnormalities in the gene encoding $\mathrm{Cu} / \mathrm{Zn}$ superoxide dismutase: molecular pathology of five new cases, and comparison with previous reports and 73 sporadic cases of ALS. J Neuropathol Exp Neurol. 1998 Oct;57(10):895-904.

Johnson ES.Protein modification by SUMO. Annu Rev Biochem. 2004;73:355-82. 
Jones RJ, Brunton VG, Frame MC. Adhesion-linked kinases in cancer; emphasis on src, focal adhesion kinase and PI 3-kinase. Eur $\mathrm{J}$ Cancer. 2000 Aug;36(13 Spec No):1595-606.

Julien JP. Amyotrophic lateral sclerosis.unfolding the toxicity of the misfolded.Cell. 2001 Feb 23;104(4):581-91.

Julien JP, Kriz J. Transgenic mouse models of amyotrophic lateral sclerosis. Biochim Biophys Acta. 2006 Nov-Dec;1762(11-12):1013-24.

Kawamata T, Akiyama H, Yamada T, McGeer PL. Immunologic reactions in amyotrophic lateral sclerosis brain and spinal cord tissue. Am J Pathol. 1992 Mar;140(3):691-707.

Kawamura MF, Yamasaki R, Kawamura N, Tateishi T, Nagara Y, Matsushita $\mathrm{T}$, et al. Impaired recruitment of neuroprotective microglia and $\mathrm{T}$ cells during acute neuronal injury coincides with increased neuronal vulnerability in an amyotrophic lateral sclerosis model. Experimental neurology. 2012 Apr;234(2):437-45.

Keizman D, Rogowski O, Berliner S, Ish-Shalom M, Maimon N, Nefussy B, et al. Low-grade systemic inflammation in patients with amyotrophic lateral sclerosis. Acta Neurol Scand. 2009 Jun;119(6):383-9.

Keller AF, Gravel M, Kriz J. Treatment with minocycline after disease onset alters astrocyte reactivity and increases microgliosis in SOD1 mutant mice. Experimental neurology. Dec 17.

Kihira T, Suzuki A, Kubo T, Miwa $H$, Kondo T. Expression of insulin-like growth factor-II and leukemia inhibitory factor antibody immunostaining on the ionized calcium-binding adaptor molecule 1-positive microglias in the spinal cord of amyotrophic lateral sclerosis patients. Neuropathology. 2007 Jun;27(3):257-68.

Kim J, Cantwell CA, Johnson PF, Pfarr CM, Williams SC. Transcriptional activity of CCAAT/enhancer-binding proteins is controlled by a conserved inhibitory domain that is a target for sumoylation. $\mathrm{J}$ Biol Chem. 2002 Oct 11;277(41):38037-44.

Kim SH, Henkel JS, Beers DR, Sengun IS, Simpson EP, Goodman JC, et al. PARP expression is increased in astrocytes but decreased in motor neurons in the spinal cord of sporadic ALS patients. J Neuropathol Exp Neurol. 2003 Jan;62(1):88-103.

Kim SH, Serezani CH, Okunishi K, Zaslona Z, Aronoff DM, Peters-Golden M. Distinct protein kinase $A$ anchoring proteins direct prostaglandin E2 
modulation of Toll-like receptor signaling in alveolar macrophages. $J$ Biol Chem. 2011 Mar 18;286(11):8875-83.

Klein R, Lamballe F, Bryant S, Barbacid M. The trkB tyrosine protein kinase is a receptor for neurotrophin-4. Neuron. 1992 May;8(5):947-56.

Klivenyi P, Kiaei M, Gardian G, Calingasan NY, Beal MF. Additive neuroprotective effects of creatine and cyclooxygenase 2 inhibitors in a transgenic mouse model of amyotrophic lateral sclerosis. $J$ Neurochem. 2004 Feb;88(3):576-82.

Kong J, Xu Z. Massive mitochondrial degeneration in motor neurons triggers the onset of amyotrophic lateral sclerosis in mice expressing a mutant SOD1. J Neurosci. 1998 May 1;18(9):3241-50.

Kostic V, Jackson-Lewis V, de Bilbao F, Dubois-Dauphin M, Przedborski S. Bcl-2: prolonging life in a transgenic mouse model of familial amyotrophic lateral sclerosis. Science. 1997 Jul 25;277(5325):559-62.

Kretz-Remy C, Mehlen P, Mirault ME, Arrigo AP. Inhibition of I kappa B-alpha phosphorylation and degradation and subsequent NF-kappa B activation by glutathione peroxidase overexpression. J Cell Biol. 1996 Jun;133(5):1083-93.

Kreutzberg GW. Microglia: a sensor for pathological events in the CNS. Trends Neurosci. 1996 Aug;19(8):312-8.

Kriz J, Nguyen MD, Julien JP. Minocycline slows disease progression in a mouse model of amyotrophic lateral sclerosis. Neurobiol Dis. 2002 Aug;10(3):268-78.

Kust BM, Copray JC, Brouwer N, Troost D, Boddeke HW. Elevated levels of neurotrophins in human biceps brachii tissue of amyotrophic lateral sclerosis. Experimental neurology. 2002 Oct;177(2):419-27.

Kwiatkowski TJ, Jr., Bosco DA, Leclerc AL, Tamrazian E, Vanderburg CR, Russ C, et al. Mutations in the FUS/TLS gene on chromosome 16 cause familial amyotrophic lateral sclerosis. Science. 2009 Feb 27;323(5918):1205-8.

Lambrechts D, Storkebaum E, Morimoto M, Del-Favero J, Desmet F, Marklund SL, et al. VEGF is a modifier of amyotrophic lateral sclerosis in mice and humans and protects motoneurons against ischemic death. Nat Genet. 2003 Aug;34(4):383-94. 
Lee ME, de la Monte SM, Ng SC, Bloch KD, Quertermous T. Expression of the potent vasoconstrictor endothelin in the human central nervous system. J Clin Invest. 1990 Jul;86(1):141-7.

Leonardo CC, Eakin AK, Ajmo JM, Collier LA, Pennypacker KR, Strongin AY, et al. Delayed administration of a matrix metalloproteinase inhibitor limits progressive brain injury after hypoxia-ischemia in the neonatal rat. J Neuroinflammation. 2008;5:34.

Levy, FAB. "Efeitos das células de Schwann cultivadas e tratadas com o PEDF no trofismo de neurônios medulares cultivados e na recuperação motora de ratos submetidos ao trauma contuso da medula espinal pelo Impactor" Dissertação do instituto de Psicologia da Universidade de São Paulo. 2008.

Li M, Ona VO, Guegan C, Chen M, Jackson-Lewis V, Andrews LJ, et al. Functional role of caspase- 1 and caspase-3 in an ALS transgenic mouse model. Science. 2000 Apr 14;288(5464):335-9.

Ling EA, Leblond CP. Investigation of glial cells in semithin sections. II. Variation with age in the numbers of the various glial cell types in rat cortex and corpus callosum. The Journal of comparative neurology. 1973 May 1;149(1):73-81.

Lobsiger CS, Cleveland DW. Glial cells as intrinsic components of non-cellautonomous neurodegenerative disease. Nat Neurosci. 2007 Nov;10(11):1355-60.

Lorenzl S, Narr S, Angele B, Krell HW, Gregorio J, Kiaei M, et al. The matrix metalloproteinases inhibitor Ro 28-2653 [correction of Ro 26-2853] extends survival in transgenic ALS mice. Experimental neurology. 2006 Jul;200(1):166-71.

Lunetta C, Serafini M, Prelle A, Magni P, Dozio E, Ruscica M, et al. Impaired expression of insulin-like growth factor-1 system in skeletal muscle of amyotrophic lateral sclerosis patients. Muscle Nerve. 2012 Feb;45(2):200-8.

Lunn JS, Hefferan MP, Marsala M, Feldman EL. Stem cells: comprehensive treatments for amyotrophic lateral sclerosis in conjunction with growth factor delivery. Growth Factors. 2009 Jun;27(3):133-40.

Ma Q, Kinneer K. Chemoprotection by phenolic antioxidants. Inhibition of tumor necrosis factor alpha induction in macrophages. J Biol Chem. 2002 Jan 25;277(4):2477-84. 
MacCumber MW, Ross CA, Snyder SH. Endothelin in brain: receptors, mitogenesis, and biosynthesis in glial cells. Proc Natl Acad Sci U S A. 1990 Mar;87(6):2359-63.

Martin LJ. Mitochondrial pathobiology in ALS.J Bioenerg Biomembr. 2011 Dec;43(6):569-79.

Martin LJ, Liu Z, Chen K, Price AC, Pan Y, Swaby JA, et al. Motor neuron degeneration in amyotrophic lateral sclerosis mutant superoxide dismutase-1 transgenic mice: mechanisms of mitochondriopathy and cell death. The Journal of comparative neurology. 2007 Jan $1 ; 500(1): 20-46$.

Marriott, D.R.; Hirst, W.D.; Ljungberb, C. Astrocytes. In: Neural Cell Culture A practical approach.; ed: Cohen J.; Wilkin.1996. 85:96.

Maruyama $\mathrm{H}$, Morino $\mathrm{H}$, Ito $\mathrm{H}$, Izumi $\mathrm{Y}$, Kato $\mathrm{H}$, Watanabe $\mathrm{Y}$, et al. Mutations of optineurin in amyotrophic lateral sclerosis. Nature. 2010 May 13;465(7295):223-6.

Matsumoto M, Funami K, Tanabe M, Oshiumi H, Shingai M, Seto $\mathrm{Y}$, et al. Subcellular localization of Toll-like receptor 3 in human dendritic cells. J Immunol. 2003 Sep 15;171(6):3154-62.

Mattiazzi M, D'Aurelio M, Gajewski CD, Martushova K, Kiaei M, Beal MF, et al. Mutated human SOD1 causes dysfunction of oxidative phosphorylation in mitochondria of transgenic mice. J Biol Chem. 2002 Aug 16;277(33):29626-33.

Mattson MP, Camandola S. NF-kappaB in neuronal plasticity and neurodegenerative disorders. J Clin Invest. 2001 Feb;107(3):247-54.

Mayers CM, Wadell J, McLean K, Venere M, Malik M, Shibata T, et al. The Rho guanine nucleotide exchange factor AKAP13 (BRX) is essential for cardiac development in mice. J Biol Chem. 2010 Apr 16;285(16):12344-54.

Mazzanti M, Sul JY, Haydon PG. Glutamate on demand: astrocytes as a ready source. Neuroscientist. 2001 Oct;7(5):396-405.

Mazzini L, Mareschi K, Ferrero I, Vassallo E, Oliveri G, Nasuelli N, et al. Stem cell treatment in Amyotrophic Lateral Sclerosis. J Neurol Sci. 2008 Feb 15;265(1-2):78-83.

Mendonca DM, Chimelli L, Martinez AM. Quantitative evidence for neurofilament heavy subunit aggregation in motor neurons of spinal 
cords of patients with amyotrophic lateral sclerosis. Braz J Med Biol Res. 2005 Jun;38(6):925-33.

Menzies FM, Ince PG, Shaw PJ. Mitochondrial involvement in amyotrophic lateral sclerosis. Neurochem Int. 2002 May;40(6):543-51.

Meyer-Franke A, Kaplan MR, Pfrieger FW, Barres BA. Characterization of the signaling interactions that promote the survival and growth of developing retinal ganglion cells in culture. Neuron. 1995 Oct;15(4):805-19.

Miana-Mena FJ, Munoz MJ, Yague G, Mendez M, Moreno M, Ciriza J, et al. Optimal methods to characterize the G93A mouse model of ALS.Amyotroph Lateral Scler Other Motor Neuron Disord. 2005 Mar;6(1):55-62.

Miller JM, McAllister JP, 2nd. Reduction of astrogliosis and microgliosis by cerebrospinal fluid shunting in experimental hydrocephalus. Cerebrospinal fluid research. 2007;4:5.

Miller TM, Johnston SC. Should the Babinski sign be part of the routine neurologic examination? Neurology. 2005 Oct 25;65(8):1165-8.

Miller TM, Smith RA, Cleveland DW.Amyotrophic lateral sclerosis and gene therapy. Nat Clin Pract Neurol. 2006 Sep;2(9):462-3.

Moreau C, Devos D, Brunaud-Danel V, Defebvre L, Perez T, Destee A, et al. Elevated IL-6 and TNF-alpha levels in patients with ALS: inflammation or hypoxia? Neurology. 2005 Dec 27;65(12):1958-60.

Morgenstern DA, Asher RA, Fawcett JW. Chondroitin sulphate proteoglycans in the CNS injury response. Prog Brain Res. 2002;137:313-32.

Morioka T, Kalehua AN, Streit WJ.The microglial reaction in the rat dorsal hippocampus following transient forebrain ischemia.J Cereb Blood Flow Metab. 1991 Nov;11(6):966-73.

Moussaud S, Draheim HJ. A new method to isolate microglia from adult mice and culture them for an extended period of time.Journal of neuroscience methods. 2010 Mar 30;187(2):243-53.

Mudter J, Amoussina L, Schenk M, Yu J, Brustle A, Weigmann B, et al. The transcription factor IFN regulatory factor-4 controls experimental colitis in mice via T cell-derived IL-6. J Clin Invest. 2008 Jul;118(7):2415-26.

Nagai M, Re DB, Nagata T, Chalazonitis A, Jessell TM, Wichterle $H$, et al. Astrocytes expressing ALS-linked mutated SOD1 release factors 
selectively toxic to motor neurons. Nat Neurosci. 2007 May;10(5):61522.

Nakamura Y, Si QS, Kataoka K. Lipopolysaccharide-induced microglial activation in culture: temporal profiles of morphological change and release of cytokines and nitric oxide. Neurosci Res. 1999 Nov;35(2):95-100.

Neusch C, Bahr M, Schneider-Gold C. Glia cells in amyotrophic lateral sclerosis: new clues to understanding an old disease? Muscle Nerve. 2007 Jun;35(6):712-24.

Nguyen KT, Garcia-Chacon LE, Barrett JN, Barrett EF, David G. The Psi $(m)$ depolarization that accompanies mitochondrial $\mathrm{Ca} 2+$ uptake is greater in mutant SOD1 than in wild-type mouse motor terminals. Proc Natl Acad Sci U S A. 2009 Feb 10;106(6):2007-11.

Nguyen MD, D'Aigle T, Gowing G, Julien JP, Rivest S. Exacerbation of motor neuron disease by chronic stimulation of innate immunity in a mouse model of amyotrophic lateral sclerosis.J Neurosci. 2004 Feb $11 ; 24(6): 1340-9$.

Nourbakhsh M, Hauser $\mathrm{H}$. Constitutive silencing of IFN-beta promoter is mediated by NRF (NF-kappaB-repressing factor), a nuclear inhibitor of NF-kappaB. EMBO J. 1999 Nov 15;18(22):6415-25.

O'Donnell SL, Frederick TJ, Krady JK, Vannucci SJ, Wood TL. IGF-I and microglia/macrophage proliferation in the ischemic mouse brain.Glia. 2002 Jul;39(1):85-97.

Ono S, Hu J, Shimizu N, Imai T, Nakagawa H. Increased interleukin-6 of skin and serum in amyotrophic lateral sclerosis. J Neurol Sci. 2001 Jun 15;187(1-2):27-34.

Panov AV, Kubalik N, Zinchenko N, Ridings DM, Radoff DA, Hemendinger R, et al. Metabolic and functional differences between brain and spinal cord mitochondria underlie different predisposition to pathology. Am J Physiol Regul Integr Comp Physiol. 2011 Apr;300(4):R844-54.

Papadimitriou D, Le Verche V, Jacquier A, Ikiz B, Przedborski S, Re DB. Inflammation in ALS and SMA: Sorting out the good from the evil. Neurobiol Dis. 2009 Oct 13.

Perlson E, Jeong GB, Ross JL, Dixit R, Wallace KE, Kalb RG, et al. A switch in retrograde signaling from survival to stress in rapid-onset neurodegeneration.J Neurosci. 2009 Aug 5;29(31):9903-17. 
Petri S, Kiaei M, Damiano M, Hiller A, Wille E, Manfredi G, et al. Cellpermeable peptide antioxidants as a novel therapeutic approach in a mouse model of amyotrophic lateral sclerosis. J Neurochem. 2006 Aug;98(4):1141-8.

Philips T, Robberecht W. Neuroinflammation in amyotrophic lateral sclerosis: role of glial activation in motor neuron disease. Lancet neurology. 2011 Mar;10(3):253-63.

Poloni M, Facchetti D, Mai R, Micheli A, Agnoletti L, Francolini G, et al. Circulating levels of tumour necrosis factor-alpha and its soluble receptors are increased in the blood of patients with amyotrophic lateral sclerosis. Neuroscience letters. 2000 Jun 30;287(3):211-4.

Pontieri FE, Ricci A, Pellicano C, Benincasa D, Buttarelli FR. Minocycline in amyotrophic lateral sclerosis: a pilot study. Neurol Sci. 2005 Oct;26(4):285-7.

Pradat PF, Dib M. Biomarkers in amyotrophic lateral sclerosis: facts and future horizons. Mol Diagn Ther. 2009;13(2):115-25.

Przedborski S, Mitsumoto H, Rowland LP. Recent advances in amyotrophic lateral sclerosis research. Curr Neurol Neurosci Rep. 2003 Jan;3(1):70-7.

Qin Y, Xu J, Aysola K, Begum N, Reddy V, Chai Y, et al. Ubc9 mediates nuclear localization and growth suppression of BRCA1 and BRCA1a proteins. J Cell Physiol. 2011 Dec;226(12):3355-67.

Ralph GS, Radcliffe PA, Day DM, Carthy JM, Leroux MA, Lee DC, et al. Silencing mutant SOD1 using RNAi protects against neurodegeneration and extends survival in an ALS model. Nat Med. 2005 Apr;11(4):429-33.

Raoul C, Buhler E, Sadeghi C, Jacquier A, Aebischer P, Pettmann B, et al. Chronic activation in presymptomatic amyotrophic lateral sclerosis (ALS) mice of a feedback loop involving Fas, Daxx, and FasL. Proc Natl Acad Sci U S A. 2006 Apr 11;103(15):6007-12.

Reis EM, Nakaya HI, Louro R, Canavez FC, Flatschart AV, Almeida GT, et al. Antisense intronic non-coding RNA levels correlate to the degree of tumor differentiation in prostate cancer. Oncogene. 2004 Aug 26;23(39):6684-92.

Renton AE, Majounie E, Waite A, Simon-Sanchez J, Rollinson S, Gibbs JR, et al. A hexanucleotide repeat expansion in C9ORF72 is the cause of 
chromosome 9p21-linked ALS-FTD. Neuron. 2011 Oct 20;72(2):25768.

Rhodes KE, Moon LD, Fawcett JW. Inhibiting cell proliferation during formation of the glial scar: effects on axon regeneration in the CNS.Neuroscience. 2003;120(1):41-56.

Rochat-Steiner V, Becker K, Micheau O, Schneider P, Burns K, Tschopp J. FIST/HIPK3: a Fas/FADD-interacting serine/threonine kinase that induces FADD phosphorylation and inhibits fas-mediated Jun $\mathrm{NH}(2)$ terminal kinase activation. J Exp Med. 2000 Oct 16;192(8):1165-74.

Rohl C, Lucius R, Sievers J. The effect of activated microglia on astrogliosis parameters in astrocyte cultures. Brain Res. 2007 Jan 19;1129(1):4352.

Rosen DR. Mutations in $\mathrm{Cu} / \mathrm{Zn}$ superoxide dismutase gene are associated with familial amyotrophic lateral sclerosis. Nature. $1993 \mathrm{Jul}$ 22;364(6435):362.

Sako W, Ito H, Yoshida M, Koizumi H, Kamada M, Fujita K, et al. Nuclear factor kappa B expression in patients with sporadic amyotrophic lateral sclerosis and hereditary amyotrophic lateral sclerosis with optineurin mutations. Clin Neuropathol. 2012 Nov-Dec;31(6):418-23.

Salman H, Bergman M, Bessler H, Wolloch Y, Punsky I, Djaldetti M. Effect of colon carcinoma cell supernatants on cytokine production and phagocytic capacity.Cancer Lett. 2000 Oct 31;159(2):197-203.

Santello M, Volterra A. TNFalpha in synaptic function: switching gears. Trends Neurosci. 2012 Oct;35(10):638-47.

Sargsyan SA, Blackburn DJ, Barber SC, Grosskreutz J, De Vos KJ, Monk $\mathrm{PN}$, et al. A comparison of in vitro properties of resting SOD1 transgenic microglia reveals evidence of reduced neuroprotective function. BMC Neurosci. 2011;12:91.

Sargsyan SA, Monk PN, Shaw PJ. Microglia as potential contributors to motor neuron injury in amyotrophic lateral sclerosis.Glia. 2005 Sep;51(4):241-53.

Sasaki S, Iwata M. Mitochondrial alterations in the spinal cord of patients with sporadic amyotrophic lateral sclerosis. J Neuropathol Exp Neurol. 2007 Jan;66(1):10-6.

Sasaki Y, Hori S, Oda K, Okada T, Takimoto M. Both ET(A) and ET(B) receptors are involved in mitogen-activated protein kinase activation 
and DNA synthesis of astrocytes: study using $\mathrm{ET}(\mathrm{B})$ receptor-deficient rats (aganglionosis rats). The European journal of neuroscience. 1998 Sep;10(9):2984-93.

Saura J, Tusell JM, Serratosa J. High-yield isolation of murine microglia by mild trypsinization. Glia. 2003 Dec;44(3):183-9.

Saxena S, Cabuy E, Caroni P.A role for motoneuron subtype-selective ER stress in disease manifestations of FALS mice. Nat Neurosci. 2009 May;12(5):627-36.

Scarisbrick IA, Asakura K, Rodriguez M. Neurotrophin-4/5 promotes proliferation of oligodendrocyte-type-2 astrocytes (O-2A). Brain Res Dev Brain Res. 2000 Sep 30;123(1):87-90.

Schmuck G, Kahl R.The use of Fluoro-Jade in primary neuronal cell cultures.Archives of toxicology. 2009 Apr;83(4):397-403.

Scorisa JM, Duobles T, Oliveira GP, Maximino JR, Chadi G. The review of the methods to obtain non-neuronal cells to study glial influence on Amyotrophic Lateral Sclerosis pathophysiology at molecular level in vitro.Acta Cir Bras. 2010 Jun;25(3):281-9.

Seeler JS, Dejean A. Nuclear and unclear functions of SUMO. Nat Rev Mol Cell Biol. 2003 Sep;4(9):690-9.

Shaw BF, Lelie HL, Durazo A, Nersissian AM, Xu G, Chan PK, et al. Detergent-insoluble aggregates associated with amyotrophic lateral sclerosis in transgenic mice contain primarily full-length, unmodified superoxide dismutase-1. J Biol Chem. 2008 Mar 28;283(13):8340-50.

Skene JP, Cleveland DW.Hypoxia and Lou Gehrig.Nat Genet.2001 Jun;28(2):107-8.

Spalloni A, Albo F, Ferrari F, Mercuri N, Bernardi G, Zona C, et al. Cu/Znsuperoxide dismutase (GLY93-->ALA) mutation alters AMPA receptor subunit expression and function and potentiates kainate-mediated toxicity in motor neurons in culture. Neurobiol Dis. 2004 Mar;15(2):340-50.

Spooren WP, Hengerer B. DNA laddering and caspase 3-like activity in the spinal cord of a mouse model of familial amyotrophic lateral sclerosis. Cell Mol Biol (Noisy-le-grand). 2000 Feb;46(1):63-9.

Stommel EW, Graber D, Montanye J, Cohen JA, Harris BT. Does treating schizophrenia reduce the chances of developing amyotrophic lateral sclerosis? Medical hypotheses. 2007;69(5):1021-8. 
Streit WJ, Walter SA, Pennell NA.Reactive microgliosis. Prog Neurobiol. 1999 Apr;57(6):563-81.

Strong MJ. The evidence for altered RNA metabolism in amyotrophic lateral sclerosis (ALS). J Neurol Sci. 2010 Jan 15;288(1-2):1-12.

Stuerenburg HJ, Kunze K. Tissue nerve growth factor concentrations in neuromuscular diseases. Eur J Neurol. 1998 Sep;5(5):487-90.

Sullivan PG, Rabchevsky AG, Keller JN, Lovell M, Sodhi A, Hart RP, et al. Intrinsic differences in brain and spinal cord mitochondria: Implication for therapeutic interventions. The Journal of comparative neurology. 2004 Jul 5;474(4):524-34.

Sun $\mathrm{H}$, Leverson JD, Hunter T. Conserved function of RNF4 family proteins in eukaryotes: targeting a ubiquitin ligase to SUMOylated proteins. EMBO J. 2007 Sep 19;26(18):4102-12.

Suzuki S, Tanaka K, Nogawa S, Dembo T, Kosakai A, Fukuuchi Y. Expression of interleukin- 6 is suppressed by inhibition of voltagesensitive $\mathrm{Na}+/ \mathrm{Ca} 2+$ channels after cerebral ischemia. Neuroreport. 2000 Aug 3;11(11):2565-9.

Suzuki T, Hide I, Ido K, Kohsaka S, Inoue K, Nakata Y. Production and release of neuroprotective tumor necrosis factor by P2X7 receptoractivated microglia. J Neurosci. 2004 Jan 7;24(1):1-7.

Tanaka F, Ikenaka K, Sobue G. [Role of axonal transport in ALS]. Rinsho Shinkeigaku. 2011 Nov;51(11):1189-91.

Terenghi F, Allaria S, Nobile-Orazio E. Circulating levels of cytokines and their modulation by intravenous immunoglobulin in multifocal motor neuropathy. J Peripher Nerv Syst. 2006 Mar;11(1):67-71.

Tovar-y-Romo LB, Tapia R. Delayed administration of VEGF rescues spinal motor neurons from death with a short effective time frame in excitotoxic experimental models in vivo. ASN Neuro. 2012;4(2).

Tracey WR, Linden J, Peach MJ, Johns RA. Comparison of spectrophotometric and biological assays for nitric oxide (NO) and endothelium-derived relaxing factor (EDRF): nonspecificity of the diazotization reaction for $\mathrm{NO}$ and failure to detect EDRF. J Pharmacol Exp Ther. 1990 Mar;252(3):922-8.

Troost D, Claessen N, van den Oord JJ, Swaab DF, de Jong JM.Neuronophagia in the motor cortex in amyotrophic lateral sclerosis. Neuropathol Appl Neurobiol. 1993 Oct;19(5):390-7. 
Tsang MC, Lo AC, Cheung PT, Chung SS, Chung SK. Perinatal hypoxia/ischemia-induced endothelin-1 mRNA in astrocyte-like and endothelial cells. Neuroreport. 2001 Jul 20;12(10):2265-70.

Turner MR, Cagnin A, Turkheimer FE, Miller CC, Shaw CE, Brooks DJ, et al. Evidence of widespread cerebral microglial activation in amyotrophic lateral sclerosis: an [11C](R)-PK11195 positron emission tomography study. Neurobiol Dis. 2004 Apr;15(3):601-9.

Turpaev K, Litvinov D, Dubovaya V, Panasyuk A, Ivanov D, Prassolov V. Induction of vascular endothelial growth factor by nitric oxide in cultured human articular chondrocytes. Biochimie. 2001 Jun;83(6):515-22.

Urushitani M, Sik A, Sakurai T, Nukina N, Takahashi R, Julien JP. Chromogranin-mediated secretion of mutant superoxide dismutase proteins linked to amyotrophic lateral sclerosis. Nat Neurosci. 2006 Jan;9(1):108-18.

Uzunova K, Gottsche K, Miteva M, Weisshaar SR, Glanemann C, Schnellhardt M, et al. Ubiquitin-dependent proteolytic control of SUMO conjugates. J Biol Chem. 2007 Nov 23;282(47):34167-75.

Van Damme P. The role of AMPA receptors and VEGF in ALS. Verh K Acad Geneeskd Belg. 2009;71(4):241-50.

Van Den Bosch L, Storkebaum E, Vleminckx V, Moons L, Vanopdenbosch L, Scheveneels W, et al. Effects of vascular endothelial growth factor (VEGF) on motor neuron degeneration. Neurobiol Dis. 2004 Oct;17(1):21-8.

Vance C, Rogelj B, Hortobagyi T, De Vos KJ, Nishimura AL, Sreedharan J, et al. Mutations in FUS, an RNA processing protein, cause familial amyotrophic lateral sclerosis type 6. Science. 2009 Feb 27;323(5918):1208-11.

Veglianese P, Lo Coco D, Bao Cutrona M, Magnoni R, Pennacchini D, Pozzi $B$, et al. Activation of the p38MAPK cascade is associated with upregulation of TNF alpha receptors in the spinal motor neurons of mouse models of familial ALS. Mol Cell Neurosci. 2006 Feb;31(2):21831.

Venters HD, Tang Q, Liu Q, VanHoy RW, Dantzer R, Kelley KW. A new mechanism of neurodegeneration: a proinflammatory cytokine inhibits receptor signaling by a survival peptide. Proc Natl Acad Sci U S A. 1999 Aug 17;96(17):9879-84. 
Wang HH, Hsieh HL, Yang CM. Nitric oxide production by endothelin-1 enhances astrocytic migration via the tyrosine nitration of matrix metalloproteinase-9. J Cell Physiol. 2011 Sep;226(9):2244-56.

Wang J, Slunt H, Gonzales V, Fromholt D, Coonfield M, Copeland NG, et al. Copper-binding-site-null SOD1 causes ALS in transgenic mice: aggregates of non-native SOD1 delineate a common feature. Hum Mol Genet. 2003 Nov 1;12(21):2753-64.

Wang L, Sharma K, Grisotti G, Roos RP. The effect of mutant SOD1 dismutase activity on non-cell autonomous degeneration in familial amyotrophic lateral sclerosis. Neurobiol Dis. 2009 Aug;35(2):234-40.

Watanabe M, Dykes-Hoberg M, Culotta VC, Price DL, Wong PC, Rothstein JD. Histological evidence of protein aggregation in mutant SOD1 transgenic mice and in amyotrophic lateral sclerosis neural tissues. Neurobiol Dis. 2001 Dec;8(6):933-41.

Werdelin L, Boysen G, Jensen TS, Mogensen P. Immunosuppressive treatment of patients with amyotrophic lateral sclerosis. Acta Neurol Scand. 1990 Aug;82(2):132-4.

West M, Mhatre M, Ceballos A, Floyd RA, Grammas P, Gabbita SP, et al. The arachidonic acid 5-lipoxygenase inhibitor nordihydroguaiaretic acid inhibits tumor necrosis factor alpha activation of microglia and extends survival of G93A-SOD1 transgenic mice. J Neurochem. 2004 Oct;91(1):133-43.

Weydt P, Hong SY, Kliot M, Moller T. Assessing disease onset and progression in the SOD1 mouse model of ALS. Neuroreport. 2003 May 23;14(7):1051-4.

Weydt P, Yuen EC, Ransom BR, Moller T. Increased cytotoxic potential of microglia from ALS-transgenic mice.Glia. 2004 Nov 1;48(2):179-82.

Wilczak N, de Vos RA, De Keyser J. Free insulin-like growth factor (IGF)-I and IGF binding proteins 2, 5, and 6 in spinal motor neurons in amyotrophic lateral sclerosis. Lancet. 2003 Mar 22;361(9362):100711.

Williamson TL, Cleveland DW. Slowing of axonal transport is a very early event in the toxicity of ALS-linked SOD1 mutants to motor neurons. Nat Neurosci. 1999 Jan;2(1):50-6.

Wilms H, Sievers J, Rickert U, Rostami-Yazdi M, Mrowietz U, Lucius R. Dimethylfumarate inhibits microglial and astrocytic inflammation by suppressing the synthesis of nitric oxide, IL-1beta, TNF-alpha and IL-6 
in an in-vitro model of brain inflammation. J Neuroinflammation. 2010;7:30.

Wong NK, He BP, Strong MJ. Characterization of neuronal intermediate filament protein expression in cervical spinal motor neurons in sporadic amyotrophic lateral sclerosis (ALS). J Neuropathol Exp Neurol. 2000 Nov;59(11):972-82.

Wong PC, Pardo CA, Borchelt DR, Lee MK, Copeland NG, Jenkins NA, et al. An adverse property of a familial ALS-linked SOD1 mutation causes motor neuron disease characterized by vacuolar degeneration of mitochondria. Neuron. 1995 Jun;14(6):1105-16.

Wong PC, Waggoner D, Subramaniam JR, Tessarollo L, Bartnikas TB, Culotta VC, et al. Copper chaperone for superoxide dismutase is essential to activate mammalian $\mathrm{Cu} / \mathrm{Zn}$ superoxide dismutase. Proc Natl Acad Sci U S A. 2000 Mar 14;97(6):2886-91.

Wu CY, Kaur C, Lu J, Cao Q, Guo CH, Zhou Y, et al. Transient expression of endothelins in the amoeboid microglial cells in the developing rat brain.Glia. 2006 Nov 1;54(6):513-25.

Wu CY, Kaur C, Sivakumar V, Lu J, Ling EA. Kv1.1 expression in microglia regulates production and release of proinflammatory cytokines, endothelins and nitric oxide. Neuroscience. 2009 Feb 18;158(4):15008.

Xiao Q, Zhao W, Beers DR, Yen AA, Xie W, Henkel JS, et al. Mutant SOD1(G93A) microglia are more neurotoxic relative to wild-type microglia. J Neurochem. 2007 Sep;102(6):2008-19.

Xu J, Watkins T, Reddy A, Reddy ES, Rao VN. A novel mechanism whereby BRCA $1 / 1 \mathrm{a} / 1 \mathrm{~b}$ fine tunes the dynamic complex interplay between SUMO-dependent/independent activities of Ubc9 on E2-induced ERalpha activation/repression and degradation in breast cancer cells. Int J Oncol. 2009 Apr;34(4):939-49.

Yamanaka K, Chun SJ, Boillee S, Fujimori-Tonou N, Yamashita H, Gutmann $\mathrm{DH}$, et al. Astrocytes as determinants of disease progression in inherited amyotrophic lateral sclerosis. Nat Neurosci. 2008 Mar;11(3):251-3.

Yamashita K, Niwa M, Kataoka Y, Shigematsu K, Himeno A, Tsutsumi K, et al. Microglia with an endothelin ETB receptor aggregate in rat hippocampus CA1 subfields following transient forebrain ischemia. $\mathrm{J}$ Neurochem. 1994 Sep;63(3):1042-51. 
Yan J, Zhou X, Guo JJ, Mao L, Wang YJ, Sun J, et al. Nogo-66 inhibits adhesion and migration of microglia via GTPase Rho pathway in vitro. J Neurochem. 2012 Mar;120(5):721-31.

Yiangou Y, Facer P, Durrenberger P, Chessell IP, Naylor A, Bountra C, et al. COX-2, CB2 and P2X7-immunoreactivities are increased in activated microglial cells/macrophages of multiple sclerosis and amyotrophic lateral sclerosis spinal cord. BMC Neurol. 2006;6:12.

Yoshihara T, Ishigaki S, Yamamoto M, Liang Y, Niwa J, Takeuchi H, et al. Differential expression of inflammation- and apoptosis-related genes in spinal cords of a mutant SOD1 transgenic mouse model of familial amyotrophic lateral sclerosis. J Neurochem. 2002 Jan;80(1):158-67.

Yoshimoto S, Ishizaki Y, Kurihara H, Sasaki T, Yoshizumi M, Yanagisawa M, et al. Cerebral microvessel endothelium is producing endothelin. Brain Res. 1990 Feb 5;508(2):283-5.

Zhang D, Hu X, Qian L, O'Callaghan JP, Hong JS. Astrogliosis in CNS pathologies: is there a role for microglia? Molecular neurobiology. Jun;41(2-3):232-41.

Zhang Q, Haydon PG. Roles for gliotransmission in the nervous system. J Neural Transm. 2005 Jan;112(1):121-5.

Zhao W, Beers DR, Henkel JS, Zhang W, Urushitani M, Julien JP, et al. Extracellular mutant SOD1 induces microglial-mediated motoneuron injury. Glia. Jan 15;58(2):231-43.

Zhao W, Xie W, Le W, Beers DR, He Y, Henkel JS, et al. Activated microglia initiate motor neuron injury by a nitric oxide and glutamate-mediated mechanism. J Neuropathol Exp Neurol. 2004 Sep;63(9):964-77.

Zoccolella S, Santamato A, Lamberti P. Current and emerging treatments for amyotrophic lateral sclerosis. Neuropsychiatr Dis Treat. 2009;5:57795.

Zona C, Pieri M, Carunchio I. Voltage-dependent sodium channels in spinal cord motor neurons display rapid recovery from fast inactivation in a mouse model of amyotrophic lateral sclerosis. J Neurophysiol. 2006 Dec;96(6):3314-22. 


\section{ANEXO A- Aprovação do Comitê de ética em pesquisa}

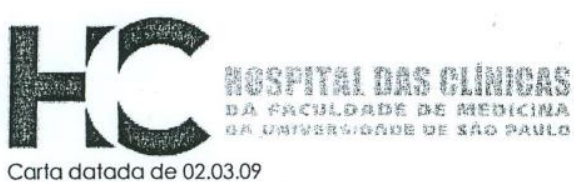

Ao

Departamento de Neurologia

O Presidente da Comissão de Ética para Análise de Projetos de Pesquisa - CAPPesq da Diretoria Clínica do Hospital das Clínicas e da Faculdade de Medicina da Universidade de São Paulo, em 17.03.09, tomou conhecimento que o Protocolo de Pesquisa $n^{\circ}$ 0113/08, intitulado: "Análise de novos mecanismos envolvidos na neurodegeneração da esclerose lateral amiotrófica. Estudo molecular no modelo experimental da doença e avaliação preliminar da possível relação com a clínica" contempla o sub-projeto intitulado: "Análise da influência da microglia mutante na sobrevida do neurônio motor no modelo in vitro da esclerose lateral amiotrófica utilizando camundongos transgênicos para SODI humana" que será tese de doutorado de IATIANA DOUBLES, tendo como orientador o PROF. DR. GERSON CHADI.

CAPPesq, em 17 de março de 2009

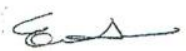

PROF. DR. EDUARDO MASSAD

Presidente da Comissão Ética para Análise

de Projetos de Pesquisa

\footnotetext{
Comissão de Ética para Análise de Projetos de Pesquisa do HCFMUSP e da FMUSP

Diretoria Clínica do Hospital das Clínicas da Faculdade de Medicina da Universidade de São Paulo Rua Ovídio Pires de Campos. 225, $5^{\circ}$ andar - CEP 05430010 - São Paulo - SP Fone: 011 - 30696442 fax : 011 - 30696492 - e-mail : cappesq@hcnet.usp.br / secretariacappesq2@hcnet.usp.br
} 


\section{ANEXO B-Moléculas selecionadas a partir dos resultados do microarray para quantificação no MC microglial}

\begin{tabular}{|c|c|c|c|}
\hline $\begin{array}{l}\text { Molécula/ } \\
\text { Função }\end{array}$ & $\begin{array}{c}\text { Gene } \\
\text { relacionado/ } \\
\text { Função }\end{array}$ & $\begin{array}{c}\text { Fold na medula } \\
\text { espinal } \\
\text { SOD3A } / \text { idade }\end{array}$ & Trabalhos relacionados/ldéias principais \\
\hline \multirow[t]{2}{*}{$\begin{array}{l}\text { NGF } \\
\text { anti-apoptótico no } \\
\text { desenvolvimento } \\
\quad \text { neuronal } \\
\text { (Colafranscesco e } \\
\text { Villoslada, 2011), } \\
\text { age também nos } \\
\text { neurônios } \\
\text { maduros. Ao Se } \\
\text { ligar no receptor } \\
\text { p75 sinaliza } \\
\text { diretamente para } \\
\text { morte celular } \\
\text { (Turner et al., } \\
\text { 2004). }\end{array}$} & $\begin{array}{c}\text { NTRK1: } \\
\text { Envolvido no } \\
\text { desenvolvimento } \\
\text { e maturação de } \\
\text { neurônios } \\
\text { centrais e } \\
\text { periféricos, } \\
\text { regulação da } \\
\text { proliferação, } \\
\text { diferenciação e } \\
\text { sobrevivência } \\
\text { neuronal. }\end{array}$ & $\downarrow 2,43$ em 40 dias & \multirow[t]{2}{*}{$\begin{array}{l}\text { - Aumento de NGF na medula espinal (Anand et al.,1995) e em músculos } \\
\text { de pacientes com ELA (Stuerenburg and Kunze, 1998; Kust et al., 2002) } \\
\text { - O tratamento com antagonista do receptor p75 em culturas de células } \\
\text { bloqueou o efeito de morte neuronal, porém não mostrou efeitos } \\
\text { estatisticamente diferentes quando reproduziu o experimento in vivo } \\
\text { (Turner et al., 2004); } \\
\text { - Ferraiolo et al. (2011) mostraram que o astrócito TG secreta mais pró- } \\
\text { NGF que faz com que aumente a expressão de receptores p75 nos } \\
\text { neurônios e aumente a morte neuronal. A inibição do p75 esta } \\
\text { relacionada com diminuição do pró-NGF. Esse trabalho também } \\
\text { observou aumento da expressão do RNAm de p75 na medula espinal de } \\
\text { pacientes com ELA; } \\
\text { - Não há trabalhos que quantificaram a quantidade de NGF secretada pela } \\
\text { microglia na ELA. Heese e colaboradores (1998) mostraram que a } \\
\text { secreção microglial de NGF aumenta com a estimulação através do LPS. }\end{array}$} \\
\hline & $\begin{array}{l}\text { p75 ou NGFR: } \\
\text { Receptor de } \\
\text { afinidade } \\
\text { secundária do } \\
\text { NGF. Indutor de } \\
\text { morte celular. }\end{array}$ & $\uparrow 1,75$ em 40 dias & \\
\hline
\end{tabular}




\begin{tabular}{|c|c|c|c|}
\hline $\begin{array}{l}\text { Molécula/ } \\
\text { Função }\end{array}$ & $\begin{array}{c}\text { Gene relacionado/ } \\
\text { Função }\end{array}$ & $\begin{array}{l}\text { Fold na medula } \\
\text { espinal SOD1 } \\
\text { idade }\end{array}$ & Trabalhos relacionados/ldéias principais \\
\hline \multirow[t]{2}{*}{$\begin{array}{c}\text { TNF-a } \\
\text { Em excesso } \\
\text { desencadeia a } \\
\text { morte neuronal; } \\
\text { Citocina pró } \\
\text { inflamatória. }\end{array}$} & $\begin{array}{l}\text { TEAD4: Fator de } \\
\text { transcrição que tem } \\
\text { papel essencial na } \\
\text { homeostase celular: } \\
\text { restrição de proliferação } \\
\text { celular e promoção da } \\
\text { apoptose (Conlon and } \\
\text { Raff, 1999). }\end{array}$ & $\uparrow 6,8$ em 40 dias & \multirow{2}{*}{$\begin{array}{l}\text { - Aumento de TEAD4 resulta em aumento de citocinas pró } \\
\text { inflamatórias (Fukushima et al., 2008); } \\
\text { - As microglias são as principais produtoras de TNF-a (Weydt et al. } \\
\text { 2004); } \\
\text { - Weydt et al (2004) demonstraram um aumento de TNF-a pelas } \\
\text { microglias TG P60 in vitro porém não mostrou dados de pureza da } \\
\text { cultura; } \\
\text { - Santello e Volterra (2012) publicaram que o TNF-a pode se } \\
\text { neuroprotetor ou não dependendo da quantidade e tempo de } \\
\text { exposição das células ao TNF-a. Ainda a ausência de TNF-o } \\
\text { sobrecarrega o sistema de captação de glutamato astrocitário } \\
\text { falha na ativação dos receptores pré-sinápticos NMDA } \\
\text { enfraquecendo a sinapse; } \\
\text { - Não há trabalhos na literatura que quantificaram a quantidade de } \\
\text { TNF-apelos astrócitos in vitro na ELA. }\end{array}$} \\
\hline & $\begin{array}{l}\text { NGFR: receptor de } \\
\text { afinidade primária ao } \\
\text { TNFA e de afinidade } \\
\text { secundária ao NGF } \\
\text { (p75). }\end{array}$ & $\begin{array}{c}\uparrow 1,75 \text { em } 40 \\
\text { dias }\end{array}$ & \\
\hline
\end{tabular}




\begin{tabular}{|c|c|c|c|}
\hline Molécula/ Função & $\begin{array}{c}\text { Gene relacionado/ } \\
\text { Função }\end{array}$ & $\begin{array}{l}\text { Fold na medula } \\
\text { espinal SOD1 }{ }^{\mathrm{G} 93 \mathrm{~A}} / \\
\text { idade }\end{array}$ & Trabalhos relacionados/ldéias principais \\
\hline $\begin{array}{c}\text { IL-6 } \\
\text { Citocina pró } \\
\text { inflamatória (Salman } \\
\text { et al., 2000) }\end{array}$ & $\begin{array}{l}\text { IRF-4: Requerido } \\
\text { para a ativação da } \\
\text { resposta imune. } \\
\text { Ativação das } \\
\text { células } \\
\text { imunocompetentes. }\end{array}$ & $\downarrow 3,76$ em 80 dias & $\begin{array}{l}\text { - Camundongos com deficiência em IRF-4 tem menor produção de } \\
\text { IL-6 (Mudter et al., 2008) e outras citocinas pró inflamatórias e são } \\
\text { resistentes a esclorese multipla experimental (Brustle et al., } \\
2007 \text { ); } \\
\text { - IRF-4- Não está descrito no contexto da ELA; } \\
\text { - Foi descrito o aumento de IL-6 no líquor (Terenghi et al., 2006), } \\
\text { soro (Moreau et al., 2005) e pele (Ono et al., 2001) de pacientes } \\
\text { com ELA; } \\
\text { - Weydt et al (2004) demonstraram uma diminuição da secreção de } \\
\text { IL-6 pelas microglias transgênicas P60 in vitro. Discutiram como } \\
\text { um resultado surpreendente e usaram o diálogo microglia } \\
\text { ativando astrócito através do TNFa e secretando IL-6 como } \\
\text { hipótese. }\end{array}$ \\
\hline $\begin{array}{c}\text { Endotelina-1 } \\
\text { São peptídeos } \\
\text { responsáveis pelo } \\
\text { tônus vascular } \\
\text { cerebral e são } \\
\text { produzidas por células } \\
\text { endoteliais, } \\
\text { neurônios,astrócitos e } \\
\text { microglias. Também } \\
\text { moduladora da } \\
\text { inflamação (Barnes e } \\
\text { Turner, 1997). }\end{array}$ & $\begin{array}{c}\text { EDNRA:Receptor } \\
\text { de endotelina-1 } \\
(\mathrm{ET}-1) .\end{array}$ & $\uparrow 2,26$ em 40 dias & $\begin{array}{l}\text { - No trabalho de Filipovich et al. (2008) foi demonstrado que as } \\
\text { endotelinas aumentaram a síntese de NO e prostaglandina nas } \\
\text { células gliais; } \\
\text { - Os efeitos deletérios da ET-1 no SNC incluem distúrbio na } \\
\text { homeostase de água e integridade da Barreira Hematoencefálica } \\
\text { (Wang et al., 2011); } \\
\text { - Altos níveis de endotelina podem induzir a ativação e proliferação } \\
\text { de astrócitos (Sasaki et al., 1998) e a regulação da secreção de } \\
\text { citocinas (Filipovich et al., 2008). }\end{array}$ \\
\hline
\end{tabular}




\begin{tabular}{|c|c|c|c|}
\hline Molécula/ Função & Gene/ Função & $\begin{array}{l}\text { Fold na medula } \\
\text { espinal SOD1 }_{\text {G93A }} \\
\text { idade }\end{array}$ & Trabalhos relacionados/ldéias principais \\
\hline $\begin{array}{c}\text { IGF } \\
\text { Fator de } \\
\text { crescimento que } \\
\text { pode agir durante o } \\
\text { desenvolvimento e } \\
\text { na } \\
\text { neurodegeneração, } \\
\text { fornecendo suporte } \\
\text { trófico aos neurônios } \\
\text { motores (Corbo et } \\
\text { al., 2010). }\end{array}$ & $\begin{array}{l}\text { IGFBP4: Codifica } \\
\text { a proteína } \\
\text { IGFBP4. Nos } \\
\text { fluídos biológicos, } \\
\text { o IGF se liga às } \\
\text { IGF-binding } \\
\text { proteins (IGFBP), } \\
\text { que agem como } \\
\text { transportadores } \\
\text { de IGF, } \\
\text { prolongando sua } \\
\text { meia vida e } \\
\text { modulando sua } \\
\text { atividade (Bach et } \\
\text { al., 2005). }\end{array}$ & $\downarrow 1,64$ em 80 dias & $\begin{array}{l}\text { - Corbo et al (2010) demontraram uma correlação entre o IGF livre } \\
\text { e a maior severidade da doença, com diminuição das IGFBPS no } \\
\text { liquor e no soro de pacientes com ELA esporádica; } \\
\text { - Kawamura et al. (2012) demonstraram em um experimento in vivo } \\
\text { uma menor imunoreatividade e expressão gênica de IGF nas } \\
\text { microglias transgênicas em relação as wild types após axotomia } \\
\text { do nervo hipoglossal lesionado do camundongo modelo da ELA } \\
\text { de } 70 \text { dias, evidenciando um potencial neuroprotetor diminuído } \\
\text { nessas células; } \\
\text { - Bellini et al. (2011) mostraram que o tratamento com IGF-I em } \\
\text { culturas de astrócitos diminuiu a expressão dos TLR4 reduzindo a } \\
\text { resposta inflamatória astrocitária e aumentando a produção de } \\
\text { IGF, evidenciando a terapia com IGF como relevante para } \\
\text { controlar a gliose reativa; } \\
\text { - A produção de IGF-I está aumentada na microglia ativada após } \\
\text { lesão no SNC (Beilharz et al., 1998; Gudi et al., 2011). Em cultura, } \\
\text { o IGF-I aumenta a proliferação microglial e astrocitária (O'Donnell } \\
\text { et al., 2002). }\end{array}$ \\
\hline
\end{tabular}




\begin{tabular}{|c|c|c|c|}
\hline $\begin{array}{l}\text { Molécula/ } \\
\text { Função }\end{array}$ & $\begin{array}{l}\text { Gene relacionado/ } \\
\text { Função }\end{array}$ & $\begin{array}{l}\text { Fold na medula } \\
\text { espinal SOD1 }{ }_{\text {G93A }} \\
\text { idade }\end{array}$ & Trabalhos relacionados/ldéias principais \\
\hline \multirow{2}{*}{$\begin{array}{c}\text { VEGF } \\
\text { Angiogênese, } \\
\text { permeabilidade } \\
\text { vascular e } \\
\text { proliferação glial, } \\
\text { e recentemente } \\
\text { outras funções } \\
\text { como } \\
\text { neuroproteção e } \\
\text { neurogênese } \\
\text { (Carmeliet, 2000). }\end{array}$} & $\begin{array}{c}\text { VEGFA: importante } \\
\text { para a formação de } \\
\text { vasos sanguíneos e } \\
\text { durante o } \\
\text { desenvolvimento. }\end{array}$ & $\downarrow 1,08$ em 40 dias & \multirow{2}{*}{$\begin{array}{l}\text { - Durante o processo de neurodegeneração aumenta a proliferação } \\
\text { astroglial e microglial através da sinalização dos receptores VEGFR- } \\
\text { 1(Boer et al., 2008); } \\
\text { - VEGF retarda a degeneração dos neurônios motores em ratos com } \\
\text { ELA (Van Damme, 2009); } \\
\text { - A expressão VEGF é diminuída nos neurônios sobreviventes na } \\
\text { ELA (Brockington et al., 2006) e seus níveis são reduzidos em } 50 \% \\
\text { no soro de pacientes com ELA (Lambrechts et al., 2003); } \\
\text { - Tovar-y-Romo e Tapia (2012) mostraram que a administração do } \\
\text { VEGF antes ou após o início dos sintomas da doença foi capaz de } \\
\text { prevenir a morte neuronal; } \\
\text { - Camundongos SOD1 }{ }^{\text {G93A }} \text { com inibição do VEGFA apresentaram } \\
\text { animais com degeneração de motoneurônios mais graves e com } \\
\text { curta expectativa de vida (Lambrechts et al., 2003); } \\
\text { - Camundongos com VEGFA silenciado são modelos experimentais } \\
\text { para ELA (Lambrechts et al., 2003); } \\
\text { - Ainda não há registros na literatura que quantificaram VEGF } \\
\text { secretado pelos astrócitos ou microglias na ELA. }\end{array}$} \\
\hline & $\begin{array}{l}\text { VEGFB: Apresenta } \\
\text { função na formação e } \\
\text { manutenção de novos } \\
\text { vasos sanguíneos } \\
\text { durante processos } \\
\text { patológicos, tem } \\
\text { importância na proteção } \\
\text { de diversos tipos de } \\
\text { neurônios como retina, } \\
\text { córtex e neurônios } \\
\text { motores na ELA (Zhang } \\
\text { et al., 2009). }\end{array}$ & $\downarrow 1,31$ em 80 dias & \\
\hline
\end{tabular}




\section{ANEXO C- Genes selecionados a partir dos resultados do microarray para quantificação da expressão gênica nas}

microglias

\begin{tabular}{|c|c|c|}
\hline Gene/ Função & $\begin{array}{l}\text { Fold na medula espinal } \\
\text { SOD } 1 \text { / idade }\end{array}$ & Trabalhos relacionados/ldéias principais \\
\hline $\begin{array}{c}\text { NKRF } \\
\text { codifica para a } \\
\text { proteína NKRF, } \\
\text { repressora do NF-K } \beta \\
\text { (Feng et al., 2002). }\end{array}$ & $\uparrow 4,96$ em 80 dias & 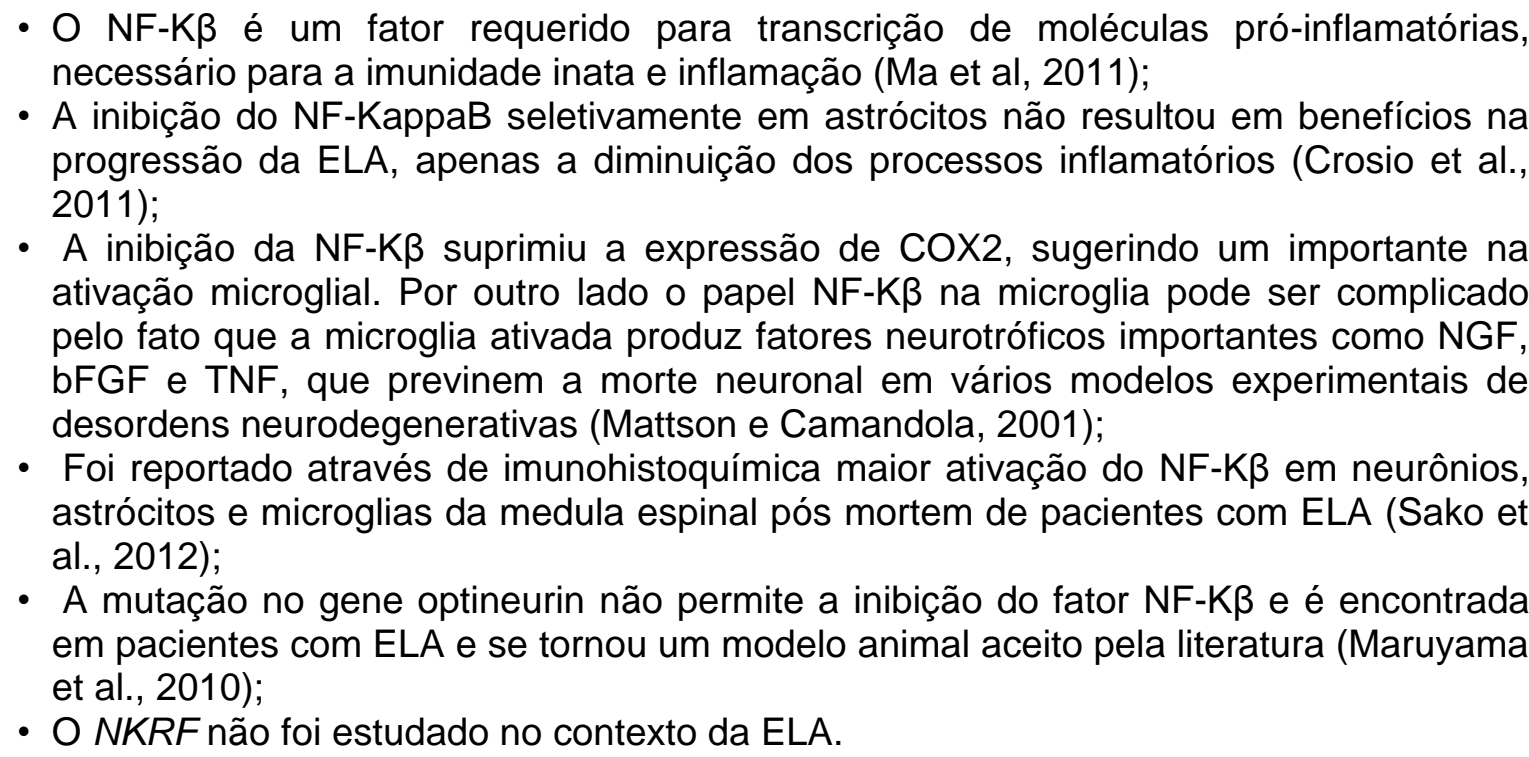 \\
\hline $\begin{array}{c}\text { HIPK3 } \\
\text { Regula a fosforilação } \\
\text { da FADD, fator } \\
\text { essencial para } \\
\text { ativação da } \\
\text { apoptose; confere } \\
\text { resistência a } \\
\text { apoptose (Curtin e } \\
\text { Cotter, 2004). }\end{array}$ & $\uparrow 2,37 \mathrm{em} 80$ dias & $\begin{array}{l}\text { - Alta expressão de HIPK3 em células cancerígenas resistentes à morte por diferentes } \\
\text { drogas (Curtin e Cotter, 2004); } \\
\text { - Rochat-Steiner e colaboradores (2000) identificaram uma nova proteína quinase de } \\
\text { interação Fas chamada FIST/HIPK3. Fas é o receptor de morte neuronal que sinaliza } \\
\text { para apoptose e está associada à FADD. O FIST/HIPK3 fosforila a FADD, porém essa } \\
\text { fosforilação parece não regular a apoptose. Apesar do ligante da Fas (FasL) ser um } \\
\text { importante indutor de apoptose, o FIST/HIPK3 ativo impede a ativação JNK pelas FasL } \\
\text { e confere resistência à apoptose; } \\
\text { - A superexpressão de HIPK3 inibe a ativação de JNK e diminui a apoptose via } \\
\text { regulação da Fas (Curtin e Cotter, 2003); } \\
\text { - Ainda não foi explorado no contexto da ELA. }\end{array}$ \\
\hline
\end{tabular}




\begin{tabular}{|c|c|c|}
\hline Gene/ Função & $\begin{array}{c}\text { Fold na medula } \\
\text { espinal SOD1 } \\
\text { idade }\end{array}$ & Trabalhos relacionados/ldéias principais \\
\hline $\begin{array}{c}\text { UBE2I } \\
\text { participa do processo } \\
\text { de sumoilação que é } \\
\text { visto como uma } \\
\text { pequena } \\
\text { ubiquitinização levando } \\
\text { à alteração na } \\
\text { atividade protéica (Xu } \\
\text { et al., 2009). } \\
\text { Relacionada com } \\
\text { regulação da } \\
\text { proliferação e morte } \\
\text { celular (Qin et al., } \\
\text { 2011). }\end{array}$ & $\begin{array}{r}\uparrow 2,04 \text { em } 80 \text { dias } \\
\uparrow 1,03 \text { em } 40 \text { dias }\end{array}$ & $\begin{array}{l}\text { - O silenciamento do UBE2I por RNAi resultou em uma retenção citoplasmática da } \\
\text { - FCRA1, causando uma intensa proliferação celular (Qin et al., 2011); } \\
\text { Foi descrito por Akar e Feinstein (2009) que a sumoilação regula a expressão de } \\
\text { NOS2 nos astrócitos. Foi demonstrado que a SUMO-Ubc9 reduz a ativação do } \\
\text { promotor NOS2 nos astrócitos, portanto a diminuição da expressão de UBE2I nessas } \\
\text { células aumenta a expressão de NOS2 e outros fatores inflamatórios tóxicos aos } \\
\text { neurônios; } \\
\text { - A produção de radicais superóxidos por macrófagos e microglia regula a sumoilação } \\
\text { (Bossis e Melchior, 2006); } \\
\text { - Não foi explorado no contexto da ELA. }\end{array}$ \\
\hline $\begin{array}{c}\text { NTF5 } \\
\text { Codifica a NT-5. } \\
\text { Sinalização pelos } \\
\text { receptores p75 e } \\
\text { TRKB (Banfield et al., } \\
\text { 2001). }\end{array}$ & $\downarrow 2,11$ em 40 dias & $\begin{array}{l}\text { - Todas as NT 3,4/5 apresentam mesma afinidade para se ligarem aos receptores p75. } \\
\text { Porém, apresentam diferentes afinidades aos receptores Trk, e o receptor Trkb é o que } \\
\text { apresenta maior afinidade para NT4/5. Ainda, as neurotrofinas podem se ligar } \\
\text { simultaneamente aos receptores Trk e p75 (Banfield et al., 2001); } \\
\text { - Duberley et al. (1997) analisaram secções cerebrais de neurônios corticais de } \\
\text { pacientes pós mortem com sALS e não observaram diferenças entre a intensidade de } \\
\text { NTF5 em relação aos controles; } \\
\text { - Outro estudo mais recente mostrou aumento nos níveis de RNAm NT-4/5 no tecido } \\
\text { muscular de pacientes com ELA durante a progressão da doença (Küst et al., 2002). }\end{array}$ \\
\hline
\end{tabular}




\begin{tabular}{|c|c|c|}
\hline Gene/ Função & $\begin{array}{l}\text { Fold na medula } \\
\text { espinal SOD1 }{ }^{\mathrm{G} 93 \mathrm{~A}} / \\
\text { idade }\end{array}$ & Trabalhos relacionados/ldéias principais \\
\hline $\begin{array}{c}\text { AKAP13 } \\
\text { é induzida pelo TLR2 } \\
\text { para ativar a via NF- } \\
\text { K } \text { e direcionar o } \\
\text { local e a resposta } \\
\text { imunológica } \\
\text { específica (Kim et al., } \\
\text { 2011); coordena a } \\
\text { via da Rho (Diviani et } \\
\text { al., 2001). }\end{array}$ & $\begin{array}{l}\uparrow 1,55 \text { em } 40 \text { dias } \\
\uparrow 2.62 \text { em } 80 \text { dias }\end{array}$ & $\begin{array}{l}\text { - Há pouca informação na literatura sobre a expressão de AKAP13 em microglia, } \\
\text { astrócitos e macrófagos; } \\
\text { - AKAP13 está diretamente relacionada com inflamação. Receptores toll like (TLR) são } \\
\text { reguladores essenciais da imunidade inata, iniciando uma cascata cumulativa na } \\
\text { ativação do fator de transcrição do NF-Kß (Matsumoto et al., 2003). Estudos recentes } \\
\text { têm mostrado que a AKAP13, uma proteína quinase, é induzida por um TLR específico } \\
\text { conhecido como TLR2 para ativar a via NF-Kß e direcionar o local e a resposta } \\
\text { imunológica específica (Kim et al., 2011); } \\
\text { - Outra função conhecida da AKAP13 é de ser uma proteína que coordena a via da Rho } \\
\text { (Diviani et al., 2001). Essa via é composta principalmente pelas moléculas Cdc42, } \\
\text { Rac1 e RhoA. Tais moléculas participam da organização do citoesqueleto e da adesão } \\
\text { célula/matriz extracelular (Jones et al., 2000), participando da mobilidade celular. A } \\
\text { AKAP13 é ativada por moléculas extracelulares como proteínas G para regular a } \\
\text { actina e o citoesqueleto, se tornando essencial para induzir a migração celular (Mayers } \\
\text { et al., } 2010 \text { ); } \\
\text { - A AKAP13 é ativada por moléculas extracelulares e regula a actina e o citoesqueleto, } \\
\text { se tornando essencial pata induzir a migração celular (Mayers et al., 2010); } \\
\text { - AKAP13 não foi explorada no contexto da ELA. }\end{array}$ \\
\hline
\end{tabular}




\section{ANEXO D- Paper submetido para a BMC neuroscience \\ Research Report}

Analysis of glial cell toxicity on spinal cord motor neurons in the SOD1 ${ }^{\text {G93A }}$ ALS mouse model: a possible involvement of NGF and TNFa signaling

Duobles T, Scorisa JM, De Oliveira GP, Maximino JR, Chadi G*

Neuroregeneration Center, Department of Neurology, University of São Paulo School of Medicine, São Paulo, Brazil, 01246-903

${ }^{*}$ Corresponding author:

Gerson Chadi, M.D., Ph.D.

Full Professor

Department of Neurology

University of São Paulo

Av. Dr. Arnaldo, 455, 2nd floor, room 2119

01246-903-São Paulo. Brazil

Phone: $55113061-7460$

E-mail address: gerchadi@usp.br 


\section{ABSTRACT}

Microglia and astrocytes seem to be involved in the pathogenesis of Amyotrophic Lateral Sclerosis (ALS). Their effects on motor neurons in the presymptomatic phase of the disease have not been characterized nor the molecules signaling cell toxicity.We evaluated the participation of these two essential glial cells from pre symptomatic ALS animal model $\left(\mathrm{SOD} 1^{\mathrm{G} 93 \mathrm{~A}}\right)$ aged 1 and 60 days through in vitro experiments. Therefore we performed microglia or astrocyte/motor neuron coculture in different cells combinations in order to analyse the. motor neuron death by FluoroJade-C staining. Neuronal cultures were also performed and treated with microglia or astrocytes conditioned medium (CM). The neurotrophism and death were quantified. Additionaly, for the first time were quantified the amount of interleukin 6 (IL-6), tumor necrosis factor-alpha (TNFa) and nerve growth factor (NGF) released by astrocytes and microgliato demonstrate their role in ALS disease.

Neuronal degeneration in CC demonstrated that TG microglia (P1 and P60) lead WT motor neuron to death. Also, TG astrocytes (P1 and P60) increased TG motor neuron death and TG astrocytes (P1) increased WT motor neuron death.

Conditioned medium treatments showed that WT microglia (P60) exerted a trophic effect on WT and TG neuron and did not lead them to death. Additionally, TG astrocytes (P1 and P60) showed decreased TG motor neurons lengths and killed WT and TG motor neurons. NGF released by TG microglia and astrocytes (P60) were increased justifying toxicity in this pre symptomatic phase. Moreover IL-6 and TNFa releasing were increased by TG P60 microglia but decreased in astrocytes.

The present study confirms the involvement of glial cells on ALS pathology playing roles already in specific points of the presymptomatic phases of the disease. Increases of both TNF $\alpha$ and IL-6 in the conditioned medium of P60 TG microglia may be correlated to direct toxic function to motor neurons, while the down regulation of those cytokines in the TG astrocyte conditioned medium might be correlated to defects on neuron-astroglial communication. Such detrimental effects of both astrocyte and microglia could be augmented by the over secretion of NGF activating its death cell receptor.

Keywords: Microglia, astrocytes and amyotrophic lateral sclerosis 


\section{Introduction}

Amyotrophic lateral sclerosis (ALS) is rapid and fatal progressive a degenerative disease characterized by selective loss of lower and upper motor neurons [1-3]. Most of ALS cases are sporadic and $20 \%$ of the rare familial ALS (FALS) cases present an autosomal dominant inheritance of SOD1 mutation [4-6]. Rodents expressing mutant form of human SOD1 are the most currently accepted experimental ALS model [7]. The degeneration of motor neurons in the ALS has mentioned to be linked to glial cell mechanisms, particularly those related to activated microglia and astrocytes [4, 5, 8-12] however the details of the induced toxicity remains to be elucidated. For instance, the details of the cell signaling, what is the period of presymptomatic phase the glial sinaling toxicity is triggered, does it continue in the course of neuronal degeneration, and the events may change during the ALS evolution possibly interfering with the disease progression are necessary knowledge in order to understand better the disease and future development of effective therapeutic target.

Microglial activation has been described in the brain and spinal cord of ALS patients [13-18] and in the spinal cord of mutant SOD1 mice models before developing symptoms [19] .Evidences from in vivo studies showed that microglia overexpressing mutant SOD1 acquired neurotoxic properties following activation [20]. Furthermore, human astrocytes derived from animal model and spinal cord of patients with sporadic and familial ALS can also promote motor neuron death in culture [21]. It seems that the glial toxicity is a complex event involving different type of astroglial/microglial interaction along phases of ALS.

The glutamate exitotoxicity of spinal cord motor neurons is one of the few described glial mechanisms in the ALS up to date, being the degenerating motor neurons surrounded by reactive astrocytes with loss of the glutamate transporter EAAT2 ALS both in the patients and animal model [5, 22-24]. However, recent evidences have put factor-alpha (TNFa) and interleukin-6 (IL-6) in the context of glial mechanisms in ALS [25]. Glial cytokines playing a role in inflammation like TNF $\alpha$ and IL-6 are upregulated in spinal cord and cerebral spinal fluid of both patients and animal model [26-28]. Although TNFa and IL-6 may act as toxic or protective factors (Raivich et al., 1999), the astroglial IL-6 -induced by TNFa [29] might amplify the microglial responses related to inflammation in neurodegenerative 
disorders [30, 31]. On the other hand TNFa acting on its TNFR1 or TNFR2 thus triggering death or survivor actions, respectively [32] might influence the rate of motor neuron degeneration along ALS evolution. Additionally, the increase of microglial TNFa might impair astroglial function on glutamate synaptic transmission $[30,33]$. The influence of TNFa rate of motor neuron degeneration might be modulated by nerve growth factor (NGF) which is also released the astrocytes and microglia, is increased during inflammatory processes is able to induce TNF- $\alpha$ expression in neurons [34, 35]. The double role of NGF, triggering neuronal protection and death by acting, respectively on its high affinity tyrosine kinase receptor type $A($ TrkA) and low affinity p75 receptor $[18,36]$ might prompt ALS neurodegeneration [37] when motor neurons up regulate $p 75$ receptor expression as described in animal model [18] and patients [38].

This work has evaluated in vitro the toxicity of microglia and astrocytes, obtained from early (post natal day 1, P1) and late (P60) presymptomatic phases of ALS, on postnatal spinal cord motor neurons of mure models of the disease. The results were correlated with the changes in the amount of NGF, TNFa and IL-6 released by those glial in the studied periods.

\section{METHODS}

\section{Animal model}

One day (P1) and 60 days (P60) -old specific pathogen-free SOD1 ${ }^{\text {G93A }}$ mice their age-paired non transgenic controls (wild-type, WT) from University of São Paulo Medical School (São Paulo, Brazil) were used in the experiments. Animals were kept under standardized lighting conditions (lights on at 7:00 $\mathrm{h}$ and off at 19:00 $\mathrm{h}$ ), at a constant temperature of $23^{\circ} \mathrm{C}$ and with free access to food pellets and tap water. The colony was derived from Jackson Laboratories (Bar Harbor, ME, USA) from SOD $1^{\text {G93A }}$ mutant mice with $25 \pm 1.5$ copies of the human SOD1 transgene [7]. Mouse identification (SOD1 ${ }^{\mathrm{G} 93 \mathrm{~A}}$ or WT) in our colony was performed by genotyping [39]. The study was conducted according protocols approved by the Animal Care and Use of Ethic Committee at the University of São Paulo and in accordance with the Guide for Care and Use of Laboratory Animals adopted by the National Institutes of Health. 


\section{Primary cell culture}

\section{Primary microglia, astrocyte and motor neuron cultures from P1 mice}

Protocols used to obtain purified motor neuron, microglia and astrocyte cell cultures from newborn WT and TG mice (P1) were described previously [39] and modified according to our experience. Briefly, for both the glial and motor neuron cultures, animals were decapitated and the skin and muscles overlying the spinal cord were dissected. Spinal cord between mid-cervical and lower lumbar levels was cut and quickly cleaned of meninges in ice-cold Hank's modified balanced salt solution (HBSS) and the tissue from each animal was processed alone in a fresh ice buffer. Neurobasal A medium and B-27 supplement were purchased from Gibco and all other reagents were obtained from Sigma.

In order to obtain the highly purified microglia culture, WT and TG spinal cords were digested with trypsin $0.25 \%$ for 30 minutes at $37^{\circ} \mathrm{C}$ under agitation. Trypsinization was stopped by adding an equal volume of D-10, which consisted of Dulbecco's modified eagle medium (DMEM) containing 10\% fetal bovine serum (FBS) and antibiotics, with $0.02 \%$ deoxyribonuclease I. The solution was pelleted, resuspended in D-10 and plated. Each spinal cord was plated individually in $1 \mathrm{ml}$ into a 6 -well plate and maintained at $37^{\circ} \mathrm{C}$ in humidified $5 \% \mathrm{CO}_{2}$ incubator. Medium was replaced every 2 days. Non purified cultures reached confluency after 14 days in vitro and 3 days later, cells were washed for 1 minute in DMEM and incubated at $37^{\circ} \mathrm{C}$ with trypsin $0.06 \%$ until intact layer is detached. This purification step takes about 4 hours. The process continues by adding D-10 and discarting the layer of detached cells. Microglial adherent cells could be grown [40]. New trypsinization was performed to replace cells onto coverslips that were used for imunohistochemical and biochemical analyses, or into a 96 well, when were used to obtain the conditioned medium.

In order to obtain the highly purified astrocyte culture, spinal cords from WT and TG mice were triturated with a 20G needle in D-10. Each resuspended spinal cord was plated individually in a 12-well plate. After 2 weeks, cells were agitated overnight in a $200 \mathrm{rpm}$ rotation to eliminate ameboid microglia and oligodendrocytes. After that, astrocytes were detached by mild trypsinization letting the ramified microglia attached [40]. Purified astrocytes were plated onto coverslips pre treated with Poly-L-Lysine in order to inhibit further microglial proliferation [41]. 
In order to obtain the highly purified motor neuron culture, spinal cords from WT and TG newborn mice were digested with trypsin diluted in PBS to a final concentration $0.025 \%$ and incubated at $37^{\circ} \mathrm{C}$ for 10 minutes. Immediately after incubation, the tissue was transferred to a new tube with L-15 medium, 4\% BSA and DNAse $(1 \mathrm{mg} / \mathrm{ml})$ and agitated vigorously by hand until tissue fragments were disaggregated. The visible fragments were transferred to another new tube with fresh solution in order to dissociate all the tissue. The solution of each spinal cord was centrifuged through a $4 \%$ BSA cushion. The pellet of cells obtained at this step was suspended and purified. The purification process of motor neurons was carried out by a centrifugation of the cell suspension through a 6\% OptiPrep cushion. After centrifugation at $800 \mathrm{~g}$ for 15 minutes with no break, a sharp band (motor neuron fraction) on the top and a pellet (glial fraction) were obtained. Motor neuron fraction was centrifuged for 7 minutes at $700 \mathrm{~g}$ and resuspended and plated at a density of $10^{5}$ into 124 -well plates pre-coated with poly-D-ornithin and laminin. Cultures were maintained with complete neuronal medium: neurobasal A medium, B27 (2\%), $0.5 \mathrm{mM}$ L-glutamine, horse serum (2\%), $25 \mu \mathrm{M}$ 2-mercaptoethanol, $25 \mu \mathrm{M}$ glutamate, penicillin and streptomycin (1\%), and $10 \mathrm{ng} / \mathrm{ml}$ BDNF. The medium was changed every 2 days. Motor neuron identity was confirmed with the presence of ChAT immunoreactivity in the vast majority of neuronal cells in the cultures (Figure 1).

\section{Primary microglia and astrocyte cultures from P60 mice}

Glial cell cultures were also obtained from spinal cord of pre-symptomatic P60 adult ALS mice. Briefly, mixed glial cultures were obtained prior purification of individual glial cell cultures. P60 WT and TG mice were perfused with saline solution to eliminate blood cells from samples. Spinal cords were removed and cleaned out meninges with fine forceps previously sterilized. Spinal cord fragments were cut and dissociated with a 19G needle in Earle's balanced salt solution. After, the tissue was pelleted by centrifugation at $700 \mathrm{~g}$ for 5 minutes and ressuspended in DMEM suplemented with $0.1 \mathrm{mg} / \mathrm{ml}$ of I-valin, $10 \%$ SFB and antibiotics. Each spinal cord was plated individually in a 6 -well, that was maintained at $37^{\circ} \mathrm{C}$ in humidified $5 \%$ $\mathrm{CO}_{2}$ incubator. After, astrocyte or microglia purification was performed as described above for P1 cultures. 


\section{Co-cultures of spinal cord motor neurons with microglia or astrocytes}

Culture of WT and TG motor neurons were performed and plated on $35 \mathrm{~mm}$ coverslips as described above. One day after plating, short neuronal lengths could be seen. WT or TG microglia or astrocyte purified cultures from P1 or P60 mice were trypsinized and plated at the density of $2.5 \times 10^{4}$ and $5 \times 10^{4}$, respectively, onto the neuronal cultures in neuronal medium. The co-culture system was established as soon as the glial cell get attached to the plate. The combination of cell types and genotypes can be found in Table 1 .

\section{Neuronal degeneration in co-cultures}

The quantifification of neuronal degeneration in co-culture $(n=3$ in each group) system was performed on day $5^{\text {th }}$. Co-cultures onto coverslips were fixed and stained with FluoroJade-C (Millipore, USA), a specific marker of neuronal degeneration. Briefly, wells were washed in PBS and fixed with $4 \%$ paraformaldehyde. After, culture cells were washed with distilled water, permeabilized with $0.2 \%$ Triton and exposed to Fluoro-Jade $\mathrm{C}$ at $0.0001 \%$ final concentration for 30 minutes in the dark. After that period, cells onto coverslips were washed 3 times with distilled water during 5 minutes and then placed on slides with mounting medium containing DAPI (Montex; Vector, USA). Six images (equidistant each other) were obtained of each coverslip/animal under fluorescent microscopy (20x magnification) and the neuronal degeneration was quantified by means of stereological methods of a point intercept frame (frame 432 points with $30 \mu m^{2}$ ). All points reaching FluoroJade-C profiles possessing a nuclei marked with DAPI were counted [42] and the mean of the 6 analyzed fields was obtained for each animal. The values of WT and TG neurons co-cultured with TG microglia or astrocytes were expressed as percentage of WT or TG neurons co-cultured with WT astrocytes or microglia. 
Table 1: Experimental groups

\begin{tabular}{c|c|c}
\hline & $\begin{array}{c}\text { WT Microglia } \\
\text { or Astrocyte }\end{array}$ & $\begin{array}{c}\text { TG Microglia } \\
\text { or Astrocyte }\end{array}$ \\
\hline \multirow{2}{*}{ WT motor neuron } & $\mathrm{P} 1$ & $\mathrm{P} 1$ \\
& $\mathrm{P} 60$ & $\mathrm{P} 60$ \\
\hline \multirow{2}{*}{ TG motor neuron } & $\mathrm{P} 1$ & $\mathrm{P} 1$ \\
& $\mathrm{P} 60$ & $\mathrm{P} 60$ \\
\hline
\end{tabular}

Experimental groups of the work were performed by co-culturing spinal cord motor neurons with spinal cord astrocytes or microglia of WT or TG SOD $1^{\mathrm{G} 93 \mathrm{~A}}$ mice or treating the cultured neurons with the conditioned medium $(\mathrm{CM})$ of the glial cell cultures. Quantification of neuronal damage or soluble factors in the glial $\mathrm{CM}$ experiments were performed using microglia and astrocytes extracted from post natal day 1 (P1) and day 60 (P60) mice. $n=3$ for each group.

\section{Neuronal degeneration after treatment with conditioned medium of glial cells}

The conditioned medium from WT and TG microglia or astrocytes from P1 and P60 were collected in order to verify the effects of factors released by microglia and astrocytes on neuronal degeneration. Astrocyte conditioned medium was collected 4 days after reaching the confluence. Microglia from both genotypes and ages were transferred to a 96 well plate and activated with $1 \mu \mathrm{g} / \mathrm{ml}$ LPS for 48 hours. After, media were collected, centrifuged $(500 \mathrm{~g}$ for 10 minutes to eliminate cells in suspension) and stored at $-70^{\circ} \mathrm{C}$. Before using, both astrocyte and microglia conditioned media were supplemented with antibiotics and also $10 \mathrm{ng} / \mathrm{ml}$ of ciliary neurotrophic factor (CNTF) and glial cell-derived neurotrophic factor (GDNF). WT and TG motor neuron cultures were submitted to a daily replacement of $20 \%$ of their media by a correspondent volume of either one of P1/P60 astrocyte or microglia conditioned medium. This procedure was repeated every day for 5 days. Furthermore, a control group of neuronal cell culture received the same type of treatment with regular neuronal medium, instead of glial conditioned medium. Stereological analyses were also performed in order to quantify FluoroJade-C positive neuronal degeneration and the neuronal length. The neuronal cultures submitted to the conditioned medium treatments were photographed before and at the day $5^{\text {th }}$ of treatment under an inverted phase contrast microscopy $(40 \mathrm{x}$ magnification) in order to quantify the neuronal lengths by means of stereological 
method employing the point intercept frame (675 points with a defined area of $4.9 \times 10^{5} \mu \mathrm{m}^{2}$ ). Six microphotographs were taken equidistant from each other. Images were superimposed to the frame and all neuronal lengths that reached the points of the frame were counted. The measurements were made on neuronal lengths that were clearly connected to the motor neuron perikarya. The sum of points scored in each image was divided by the number of neurons of that image.

\section{ELISA Immunoassay}

Samples of activated microglia and astrocytes conditioned media from both genotypes and ages were centrifugated, collected and stored at $-70^{\circ} \mathrm{C}$ until use. Briefly, samples, calibrators and standard curve were incubated in wells pre sensibilized with the antigen of interest. NGF, TNF $\alpha$ and IL-6 kits (Millipore) were used. Next, wells were incubated with the enzyme conjugated. Between the incubations were made some washes to remove non reactive components and unbound antibodies. After that, TMB substract were incubated which reacts with enzymatic conjugate producing color which was measured by spectrophotometer after the addition of the stop solution. Then, the optical density of each well was determined by spectrophotometer with a $\lambda$ of $450 \mathrm{~nm}$ (BioTek). Reading was performed based on a standard curve that was done with the specific antibody of each kit and expressed in $\mathrm{pg} / \mathrm{ml}$ were measured. 


\section{RESULTS}

\section{Motor neuron degeneration}

The analyses of the toxic effects of molecules released by astrocytes and microglia of P1 and P60 transgenic mice and present in the conditioned media of those glial cells on WT or TG spinal cord motor neurons are shown in the Figures 2 and 3. The presence of FluoroJade-C labeling in the cytoplasm of degenerating motor neurons which nuclei were stained with DAPI in the neuronal cultures treated with the conditioned medium of microglia and astrocyte is illustrated in the figure $2 \mathrm{C}$ and D, respectively. FluoroJade-C labeling/DAPI nuclei were counted by means of stereological quantification of neuronal degeneration.

Microglial CM of P1 and P60 TG mice did not increased the death of cultured motor neurons of WT and TG mice (Figure 3A). The analysis of astroglial CM on FluoroJade-C marker of motor neuron degeneration revealed that TG P1 and P60 astrocytes triggered an elevated rate of death of cultured spinal cord neurons of both WT and TG mice compared to the effects of astrocytes CM on WT motor $(p<0.05$; Figure 3B).

The analysis of the spinal cord motor neuron death was also evaluated in the co-culture experiments of neuron/microglia and neuron/astrocytes cells (Figures $3 A, B)$. WT motor neurons co-cultured with $P 1$ and P60 TG microglia underwent higher death compared to the co-cultures of TG neurons with either P1 or P60 WT microglia $(p<0.05$; Figure $3 A)$. Also, no increased motor neuron death was found in the co-cultures of TG neurons/P1 or P60 TG microglia comparing to the co-cultures of TG neurons with P1 or P60 WT microglia (Figure 3A).

Regarding the effects astrocytes on co-cultured spinal cord motor neurons, it was found that TG P1 and TG P60 astrocytes increased TG motor neuron death compared to the effects of P1 or P60 WT astrocytes on WT motor neurons $(p<0.05$; Figure 3B). 


\section{Neuronal length analysis}

The effects of conditioned medium of microglia and astrocytes on the length of motor neurons were also analyzed. The neuronal lengths were quantified stereologically on the day 5 of conditioned medium treatments and data were expressed as percentage of the values obtained on the day before the beginning of the treatment (pre treatment) in order to demonstrate the rate of neuronal length growth (Figure 4). Effects of respective glial media on WT and TG neuronal length were also compared to neuronal length of respective WT and TG motor neurons treated with normal neuronal medium throughout period of analysis.

The treatment with the conditioned media of WT and TG P1 microglia cultures promoted no effects on the rate of length growth of WT and TG motor neuron (Figure 4A). Furthermore, the conditioned medium of WT P60 microglia culture increased neuronal length growth rate of the both WT and TG neurons compared to respective WT and TG neurons treated with their normal neuronal media used as a controls, according to one way ANOVA $(p<0.05$; Figure 4B; also illustrated in Figure 5). Those effects of WT P60 microglia conditioned medium described above were not found after the treatment with the conditioned medium of TG P60 microglia (Figure 5B). Furthermore, statistical analyses have also shown that treatments with conditioned media of the both TG P1 and P60 astrocyte cultures are able to decrease the neuronal length growth rate of the TG neurons compared to TG neurons treated with normal neuronal medium, used as control $(p<0.05$; Figure 5C,D; also illustrated in Figure 5), effects that were not obtained by the WT neurons treated with conditioned media of P1 or P60 microglia cultures (Figure 5 C,D).

\section{TNFa, IL-6 and NGF in glial conditionated medium}

The cytokines released by microglia and astrocytes were quantified in the respective conditioned medium by means of ELISA sandwich. A higher level TNFa (37.9\%) was found in the conditioned medium of TG P60 microglia culture compared to that found in the conditioned medium of WT P60 microglia culture $(p<0.01$; Figure 6A). No change in the level of TNFa was detected in the comparison of $W T$ and TG P1 microglia conditioned media $(p<0.01$; Figure $6 A)$. 
Furthermore, a lower level TNFa was found in the conditioned medium of TG P60 astrocyte culture (89.3\%) compared to that found in the conditioned medium of WT P60 astrocyte culture $(p<0.01$; Figure $6 A)$. No change in the level of TNFa was detected in the comparison of WT and TG P1 astrocytic conditioned media, however the level of the cytokine was higher in the conditioned medium of WT P60 (90.7\%) compared to that found in the WT P1 astrocyte cultures $(p<0.01$; Figure $6 A)$.

The quantification of IL- 6 in the conditioned media of microglia and astrocyte cultures obtained from the spinal cord of the WT and TG mice of P1 and P60 showed an interesting similar fashion to that found to TNFa in the corresponded media. A higher level IL-6 (94.9\%) was found in the conditioned medium of TG P60 microglia culture compared to that found in the conditioned medium of WT P60 microglia culture $(p<0.05$; Figure $6 C)$. No change in the level of IL-6 was detected in the comparison of WT and TG P1 microglia conditioned media, however the level of the cytokine was higher in the microglial conditioned medium of TG P60 (91.6\%) compared to that found in the TG P1 microglia cultures $(p<0.01$; Figure $6 C)$. Furthermore, a lower level IL-6 was found in the conditioned medium of TG P60 astrocyte culture (363\%) compared to that found in the conditioned medium of WT P60 astrocyte culture $(p<0.01$; Figure $6 D)$. No change in the level of IL-6 was detected in the comparison of WT and TG P1 astrocyte conditioned media, however the level of the cytokine was higher in the conditioned medium of WT P60 (1068\%) compared to that found in the WT P1 astrocyte cultures $(p<0.05$; Figure $6 D)$.

The levels of NGF were also quantified in the conditioned media of microglia and astrocyte cultures of the experimental groups analyzed in this work. Despite of the regulation of the NGF levels was in the same direction to that observed for TNF $\alpha$ and IL-6 in the conditioned medium of the P60 TG microglia culture a down regulation in the level of NGF was in the opposite direction to that described for TNFa and IL-6 P60 TG microglia culture obtained from the spinal cord of the WT and TG mice of P1 and P60. In fact, a higher level NGF (128.4\%) was found in the conditioned medium of TG P60 microglia culture compared to that found in the conditioned medium of WT P60 microglia culture ( $p<0.05$; Figure $6 \mathrm{E})$. No change in the level of NGF was detected in the comparison of WT and TG P1 microglia conditioned media, however the level of the cytokine was higher in the microglial conditioned medium of WT P60 (71.8\%) compared to that found in the WT P1 
microglia cultures $(p<0.001$; Figure $6 E$ ). Furthermore, a higher level NGF was found in the conditioned medium of TG P60 astrocyte culture (255.3\%) compared to that found in the conditioned medium of WT P60 astrocyte culture $(p<0.001$; Figure 6F). No change in the level of NGF was detected in the comparison of WT and TG P1 astrocyte conditioned media (Figure 6F).

\section{Discussion}

Increased evidences have pointed out the motor neuron death in ALS as a non-cell autonomous process [8, 41, 43]. Selective ubiquitously expression of mutant SOD1 in the spinal cord motor neurons in the ALS mouse model do not lead per si the degeneration of motor neurons [44-46]. Furthermore, selective mutant SOD1 expression in astrocytes or microglia also seems to do not trigger motor neuron degeneration in the animal model in vivo [47, 48]. Despites the necessity of the presence of SOD1 in motor neurons, its co-expression in the neighboring noneuronal cells may play a role in motor-neuron degeneration. In fact, the current knowledge indicates that surrounding glial cells may interfere with the course of neuronal degeneration in ALS [49] however, the exact mechanisms of the toxic cellular communication remain uncertain. Moreover, diminished expression of mutant SOD1 in microglial or astrocytes significantly slowed the clinical disease progression rather than onset in murine models [4, 49]. Conversely, experiments employing chimeric mice in which only some cells expressed mutant SOD1 and experiments with SOD1 mice that expressed mutant SOD1 that could be deleted in a cell specific way, and also analysis on selective motor neuron delivery of interfering RNA against human SOD1 have correlated the presence of mutant SOD1 in the motor neurons with the disease onset without modifying the disease course $[4,8,49]$.

Remarkably, early pathological events in ALS are the activation of astrocytes and microglia in the ventral horn of the spinal cord. Microglia and astrocytes become activated before motor neurons disappear from the lumbar spinal cord of asymptomatic mutant SOD1 ${ }^{\mathrm{G} 93 \mathrm{~A}}$ transgenic mice [50]. Astroglia/microglia activation increases further until the end stage of disease [50, 51]. By knowing that glial activation orchestrates mechanisms related to neuronal maintenance/trophism and 
clearance, the impairment of those actions triggered by an unknown event in the nervous tissue at some point of presymptomatic phase of ALS might promote a cumulative toxic state to motor neurons that will die later. Conversely, once motor neuron degeneration has been started, which coincides with the onset of classical clinical symptoms, the continued process of astrocyte and microglia activation might influence the disease course by a distinct mechanism. The hypothesis may be of substantial importance since it highlights the glial mechanisms as potential therapeutical targets in different phases of the ALS disease [4, 8]. Thus, a possible toxicity of astrocytes and microglia at early presymptomatic phase of ALS is a matter of investigation.

In order to determine whether microglia or astrocytes might exert toxic effects to spinal cord motor neurons at pre-symptomatic phases of ELA, we have used co-culture system of glial cells/neurons and also analyzed the effects of conditioned medium of glial cells to neurons of the SOD1 ${ }^{\text {G93A }}$ mouse model, employing glial cells obtained from spinal cord of P1 and P60 presymptomatic animals. The in vitro studies performed in this work showed TG microglia and astrocytes can induce apoptosis in motor neuron cultures by means of FluoroJade-C stained.

Despite the motor neurons of WT and TG mice became the target of TG microglia and astrocyte toxicity, the co-culture system evidenced that P1 and P60 TG astrocytes clearly induced motor neuron degeneration in TG neurons and that P1 and P60 TG microglia led a higher degeneration to WT motor neurons. Furthermore, the toxic signaling of transgenic glia may involve the secretion of soluble factors that are able to spread the deleterious action because the treatments with the conditioned medium of TG microglia and astrocyte added new toxic events to motor neurons. It should be also noticed that the glial toxicity was not restricted to glial cultures from P60 SOD1G93A mice but also from neonatal P1 animals. All in all, the glial toxicity to motor neurons might be a chronic event leading to motor neuron degeneration when protective mechanisms fail. Our results in vitro have detailed the analysis of the toxicity promoted by TG microglia described previously using in vivo methodology [8] and are in agreement to co-culture studies that have shown motor neurons death in the presence astrocytes from SOD1 animal model and patients with ALS [21, 41] extended the analysis by detailing the toxicity 
promoted by TG microglia in vitro and astrocytes from different presymptomatic phases. Our findings on effects of conditioned medium of glial cells also agree similar to previous results of in vitro experiments with motor neurons submitted to treatment with conditionated medium from TG astrocytes from SOD1 ${ }^{\text {G93A }}$ [41] or astrocytes from familial and sporadic ALS patients [21] showing an increased neuronal death compared with healthy astrocytes conditionated medium. However, the basis of astrocyte toxicity and failure of motor neuron support remain uncertain.

In fact, the complex microglial signaling led motor neuron protection or injury in ALS, despite the triggering for both is still unknown [4, 47, 52]. WT microglia are less toxic to TG motor neurons than their TG counterpart and also might drive neuroprotective effect by expressing neurotrophic molecules able to extend survival of ALS mice, being the behavior of TG microglia in the opposite direction in this context [53,54]. Al in all, our results emphasize TG microglia and astrocytes as participates of neuropathology of ALS. The knowledge of molecular signaling governing glial toxicity in ALS is the next step to understand better the physiopathology of the disease and future development of effective therapy.

Initial findings on that concern are already available. For instance, integrin down regulation TG microglia [20] might play a role by impairing the normal microglial function of cell adhesion and motility which are important mechanisms in the neurotrophic surveillance. Furthermore, microglia lacking mutante SOD1 triggered motoneuron protection and extended the TG mouse survival [47].

We have added knowledge in the mechanisms of glial toxicity in ALS by measuring the levels of TNFa, IL-6 and NGF in the conditioned medium of cultured microglia and astrocytes from spinal cord of SOD $1^{\text {G93A }}$ ALS mouse model the two studied pre-symptomatic phases of disease. Those cytokines were chosen because their play specific signaling on glial actions to neurons in physiological state and pathological conditions [55]. The conditioned medium of TG microglia of P60 mice accumulated increased levels of TNFa compared to their WT control. Conversely, the conditioned medium of TG astrocytes of P60 mice accumulated lower levels of TNFa compared to their WT control. In fact, despite microglia are the main producers of TNFa in the central nervous system [25], TNFa is a pro-inflammatory cytokine released more abundantly by reactive astrocytes and microglia in neuropathological conditions. Increased levels of TNFa were found in the serum of 
ALS patients and in SOD1 ${ }^{\text {G93A }}$ spinal cord [27]. Furthermore, TNFR1 and TNFR2 receptors are also upregulated in ALS, event that was correlated to the disease severity [26]. The inflammatory cytokines, TNF- $\alpha$ in especial, are able to trigger neuronal excitotoxicity by disrupting the ion balance and the expression of neuronal ion channels and neurotransmitter ionotropic receptors [56]. As TNF- $\alpha$ also regulates constitutively the glutamate release in astrocytes (Santello and Volterra, 2012), the increases of TNFa release by SOD $1^{\text {G93A }}$ microglia seen in our conditioned medium experiments, which is in accordance to previously description [25] in vivo, might be responsible for motor neuronal death in vitro due increased neuroexcitability.

Furthermore, stromal-cell-derived factor (SDF1) is another cytokine that belongs to the CXC subfamily and is the only known ligand for the membrane-bound G-protein-coupled receptor CXCR4 [57]. SDF1/CXCR4 signaling is the main pathway of TNFa production astrocytes and it is impaired in SOD1 ${ }^{\text {G93A }}$ mice [58]. The low level of TNFa in the conditioned medium of TG P60 astrocytes described here may be related, opening up de possibility of that signaling play actions on astrocyte toxicity in ELA.

Here, we also demonstrated P60 TG higher and lower levels of IL-6 in the conditioned media of TG P60 microglia and astrocytes, respectively, and such regulation might play actions in the mechanisms of microglial/astroglial toxicicity in ALS. In fact, despites abundant IL-6 be present in the healthy nervous tissue [59], it has been described that transgenic mice overexpressing IL-6 develop progressive neuronal loss and it is persistently increased in neurologic diseases like ALS [60]. Additionally, as TNFa modulates the IL-6 secretion [61], the results of the differential contents of those cytokines in the both glial conditioned media obtained in this work emphasize TNF $\alpha$ and IL-6 as important candidates for the glial toxicity in ALS.

ELISA sandwich also showed increased amounts of NGF in the conditioned media of both P60 TG microglia and P60 TG astrocyte compared to WT controls, suggesting a mechanism of direct contribution to neuronal death because ALS motor neurons express high levels of p75, a receptor death of NGF [43]. In fact, the neurotrophic actions of NGF acting thought its high affinity TrkA [62] could be shifted towards neuronal death after an over expression of its low affinity NGF receptor, p75 $[63,64]$. NGF signaling is in the context of neurodegenerative diseases $[1,65]$, 
including ALS. Increased NGF levels were reported in the lateral column of ALS spinal cord [66], in skeletal muscles of sporadic ALS patients [67] and in ALS mice spinal cord [68]. Recent studies have shown an increase of NGF in CSF of ALS patients, as well as over-expression of p75 mRNA in spinal motoneurons [43]. Moreover, NGF released in culture medium by SOD1 mutant astrocytes triggered apoptosis in cultured motor neurons [68]. Additionally, cultured motor neurons in contact with SOD $1^{\mathrm{G} 93 \mathrm{~A}}$ astrocytes express $\mathrm{p} 75$ receptor not only on the cell body, but also in axons and dendrites [43]. Our work contributed to this issue by describing a possible increased release of NGF by TG microglia emphasizing the importance of the modulatory actions between those glial cell populations in the mechanisms of ALS [47-49].

\section{Conclusion}

The present study confirms the involvement of glial cells on ALS pathology playing roles already in specific points of the presymptomatic phases of the disease. In general, TG microglia and TG astrocytes of P1 and P60 led to toxicity to both WT and TG neurons depending on the type of in vitro analyses. Increases of both TNFa and IL- 6 in the conditioned medium of P60 TG microglia may be correlated to direct toxic function to motor neurons, while the down regulation of those cytokines in the TG astrocyte conditioned medium might be correlated to defects on neuronastroglial communication. Such detrimental effects of both astrocyte and microglia could be increased by the over secretion of NGF activating its death cell receptor.

Acknowledgement. The study was supported by grants from FAPESP, Sao Paulo, and CNPq, Brasilia, Brazil. 


\section{Figures Captions}

Figure 1. Co-culture immunostaining. Microphotographs of co-cultures of motor neurons with microglia $(A)$ or astrocytes $(B)$ from spinal cord of SOD1 ${ }^{\mathrm{G} 93 \mathrm{~A}}$ neonatal mice. Motor neurons, microglia and astrocytes were imunnostained by ChAT (reddish color), CD11b (greenish color) and GFAP (greenish color), respectively. Nuclei were stained with DAPI (bluish color). Photographs were obtained after 5 days of co-culture. See text for details. Scale bars $=100 \mu \mathrm{m}(\mathrm{A})$ and $10 \mu \mathrm{m}(\mathrm{B})$.

Figure 2: FluoroJade-C staining of motor neuron death. Microphotographs illustrating the presence of FluoroJade-C positive neurons (greenish color, pointed by arrows) used to count the cells in the process of death when co-cultured with microglia $(A)$ or astrocytes $(B)$ or treated with the conditioned media of microglia $(C)$ or astrocyte (D). Motor neurons, astrocytes and microglia were obtained from spinal cord of SOD $1^{\mathrm{G} 93 \mathrm{~A}}$ neonatal mice. Nuclei were stained with DAPI (blue color). Scale bars $=100 \mu \mathrm{m}$.

Figure 3: Motor neuron death promoted by glial cells after conditioned media (CM) treatment or co-culture (CC). Graphs showing the proportion of motor neuron death promoted by $\mathrm{P} 1$ or $\mathrm{P} 60$ microglia $(\mathrm{A})$ and astrocyte $(\mathrm{B})$ after $\mathrm{CM}$ treatment or CC. Wild-type (WT) neurons treated or co-cultured with WT microglia or astrocyte were used as control and correspond to the $100 \%$ line. (A) P1 and P60 transgenic (TG) microglia co-cultured with WT neurons showed increased motor neuron death compared to control. (B) P1 and P60 TG astrocytes co-cultured with TG neurons showed increased motor neuron death compared to respective control. Also, WT neurons treated with P1 and P60 TG astrocyte CM showed increased motor neuron death compared to respective control. * $p<0,05$, one-way ANOVA, followed by Bonferroni post-test. Means \pm SEM. 
Figure 4: Motor neurons under phase contrast microscopy. Microphotographs illustrating the effects of treatment of the $\mathrm{CM}$ of microglia or astrocytes on the length of motor neuron processes of SOD1 ${ }^{\mathrm{G} 93 \mathrm{~A}}$ spinal cord transgenic (TG) mice in relation to treatments of $\mathrm{CM}$ of glial cell obtained from wild-type (WT) mice or regular neuronal medium. WT microglia CM $(A)$ increased motor neuron length in relation to control medium (E) and TG microglia CM (C). The TG astrocyte CM (B) led to a retraction of the TG motor neuron lengths compared to control medium (E) or WT astrocyte $\mathrm{CM}$ treatments $(\mathrm{B})$. Scale barrs $=5 \mu \mathrm{m}$

Figure 5: Motor neuron length. Graphs showing the percentage of the amount of motor neuron length of cultured spinal cord motor neurons from wild-type (WT) and SOD1 ${ }^{\text {G93A }}$ (TG) neonatal mice after P1 or P60 microglia and astrocyte conditioned media (CM) treatments. Neuronal medium was also used as control (M). (A) No statistical difference between groups was observed in motor neuron length after $\mathrm{P1}$ microglia CM treatment. (B) P60 WT microglia showed increased motor neuron length compared to neurons treated with their own medium (M). (C-D) Both P1 and P60 transgenic (TG) astrocytes promoted decrease TG in motor neuron length compared to $M$. * $\mathrm{p}<0,05$, one-way ANOVA, followed by Bonferroni post-test. Means \pm SEM.

Figure 6: IL-6, TNFa and NGF secretion in microglia and astrocyte conditioned media (CM). Graphs showing amount of TNFa (A-B), IL-6 (C-D) and NGF (E-F) released in $\mathrm{P} 1$ or $\mathrm{P} 60$ microglia and astrocyte $\mathrm{CM}$, respectively. The cells were obtained from the spinal cord of $\mathrm{P} 1$ or P60 wild-type (WT) and SOD1 ${ }^{\text {G93A }}$ (TG) neonatal mice. ${ }^{*} p<0,05,{ }^{* *} p<0,01$ and ${ }^{* * *} p<0,001$ one-way ANOVA, followed by Bonferroni post-test. And \# $p<0,05$, \# \# $p<0,01$ and \# \# \# $p<0,001$ Student t-test. Means \pm SEM. 
References

1. Allen SJ, Dawbarn D: Clinical relevance of the neurotrophins and their receptors. Clin Sci (Lond) 2006, 110(2):175-191.

2. Naganska E, Matyja E: Amyotrophic lateral sclerosis - looking for pathogenesis and effective therapy. Folia Neuropathol 2011, 49(1):1-13.

3. Van Den Bosch L, Robberecht W: Crosstalk between astrocytes and motor neurons: what is the message? Exp Neurol 2008, 211(1):1-6.

4. Boillee S, Vande Velde C, Cleveland DW: ALS: a disease of motor neurons and their nonneuronal neighbors. Neuron 2006, 52(1):39-59.

5. Bruijn LI, Miller TM, Cleveland DW: Unraveling the mechanisms involved in motor neuron degeneration in ALS. Annu Rev Neurosci 2004, 27:723749.

6. Ince PG, Tomkins J, Slade JY, Thatcher NM, Shaw PJ: Amyotrophic lateral sclerosis associated with genetic abnormalities in the gene encoding $\mathrm{Cu} / \mathrm{Zn}$ superoxide dismutase: molecular pathology of five new cases, and comparison with previous reports and 73 sporadic cases of ALS. $J$ Neuropathol Exp Neurol 1998, 57(10):895-904.

7. Gurney ME: Transgenic-mouse model of amyotrophic lateral sclerosis. N Engl J Med 1994, 331(25):1721-1722.

8. Clement AM, Nguyen MD, Roberts EA, Garcia ML, Boillee S, Rule M, McMahon AP, Doucette W, Siwek D, Ferrante RJ et al: Wild-type nonneuronal cells extend survival of SOD1 mutant motor neurons in ALS mice. Science 2003, 302(5642):113-117.

9. Fischer LR, Culver DG, Tennant P, Davis AA, Wang M, Castellano-Sanchez A, Khan J, Polak MA, Glass JD: Amyotrophic lateral sclerosis is a distal axonopathy: evidence in mice and man. Exp Neurol 2004, 185(2):232240.

10. Lobsiger CS, Boillee S, Cleveland DW: Toxicity from different SOD1 mutants dysregulates the complement system and the neuronal regenerative response in ALS motor neurons. Proc Natl Acad Sci U S A 2007, 104(18):7319-7326.

11. Neusch C, Bahr M, Schneider-Gold C: Glia cells in amyotrophic lateral sclerosis: new clues to understanding an old disease? Muscle Nerve 2007, 35(6):712-724.

12. Saxena S, Cabuy E, Caroni P: A role for motoneuron subtype-selective ER stress in disease manifestations of FALS mice. Nat Neurosci 2009, 12(5):627-636.

13. Engelhardt $\mathrm{Jl}$, Appel SH: IgG reactivity in the spinal cord and motor cortex in amyotrophic lateral sclerosis. Arch Neurol 1990, 47(11):12101216.

14. Henkel JS, Engelhardt JI, Siklos L, Simpson EP, Kim SH, Pan T, Goodman JC, Siddique T, Beers DR, Appel SH: Presence of dendritic cells, MCP-1, and activated microglia/macrophages in amyotrophic lateral sclerosis spinal cord tissue. Ann Neurol 2004, 55(2):221-235. 
15. Kawamata $\mathrm{T}$, Akiyama $\mathrm{H}$, Yamada $\mathrm{T}$, McGeer PL: Immunologic reactions in amyotrophic lateral sclerosis brain and spinal cord tissue. $A m \mathrm{~J}$ Pathol 1992, 140(3):691-707.

16. McGeer PL, McGeer EG, Kawamata T, Yamada T, Akiyama H: Reactions of the immune system in chronic degenerative neurological diseases. Can J Neurol Sci 1991, 18(3 Suppl):376-379.

17. Troost D, Claessen N, van den Oord JJ, Swaab DF, de Jong JM: Neuronophagia in the motor cortex in amyotrophic lateral sclerosis. Neuropathol Appl Neurobiol 1993, 19(5):390-397.

18. Turner BJ, Murray SS, Piccenna LG, Lopes EC, Kilpatrick TJ, Cheema SS: Effect of p75 neurotrophin receptor antagonist on disease progression in transgenic amyotrophic lateral sclerosis mice. J Neurosci Res 2004, 78(2):193-199.

19. Henkel JS, Beers DR, Siklos L, Appel SH: The chemokine MCP-1 and the dendritic and myeloid cells it attracts are increased in the mSOD1 mouse model of ALS. Mol Cell Neurosci 2006, 31(3):427-437.

20. Sargsyan SA, Blackburn DJ, Barber SC, Monk PN, Shaw PJ: Mutant SOD1 G93A microglia have an inflammatory phenotype and elevated production of MCP-1. Neuroreport 2009, 20(16):1450-1455.

21. Haidet-Phillips AM, Hester ME, Miranda CJ, Meyer K, Braun L, Frakes A, Song S, Likhite S, Murtha MJ, Foust KD et al: Astrocytes from familial and sporadic ALS patients are toxic to motor neurons. Nat Biotechnol 2011, 29(9):824-828.

22. Almer G, Vukosavic S, Romero N, Przedborski S: Inducible nitric oxide synthase up-regulation in a transgenic mouse model of familial amyotrophic lateral sclerosis. J Neurochem 1999, 72(6):2415-2425.

23. Hirano A: Neuropathology of ALS: an overview. Neurology 1996, 47(4 Suppl 2):S63-66.

24. Howland DS, Liu J, She Y, Goad B, Maragakis NJ, Kim B, Erickson J, Kulik $J$, DeVito L, Psaltis $G$ et al: Focal loss of the glutamate transporter EAAT2 in a transgenic rat model of SOD1 mutant-mediated amyotrophic lateral sclerosis (ALS). Proc Natl Acad Sci U S A 2002, 99(3):1604-1609.

25. Weydt P, Yuen EC, Ransom BR, Moller T: Increased cytotoxic potential of microglia from ALS-transgenic mice. Glia 2004, 48(2):179-182.

26. Cereda C, Baiocchi C, Bongioanni P, Cova E, Guareschi S, Metelli MR, Rossi B, Sbalsi I, Cuccia MC, Ceroni M: TNF and sTNFR1/2 plasma levels in ALS patients. $J$ Neuroimmunol 2008, 194(1-2):123-131.

27. Moreau C, Devos D, Brunaud-Danel V, Defebvre L, Perez T, Destee A, Tonnel AB, Lassalle $P$, Just N: Elevated IL-6 and TNF-alpha levels in patients with ALS: inflammation or hypoxia? Neurology 2005, 65(12):1958-1960.

28. Terenghi F, Allaria S, Nobile-Orazio E: Circulating levels of cytokines and their modulation by intravenous immunoglobulin in multifocal motor neuropathy. J Peripher Nerv Syst 2006, 11(1):67-71. 
29. Sawada M, Suzumura A, Marunouchi T: TNF alpha induces IL-6 production by astrocytes but not by microglia. Brain Res 1992, 583(12):296-299.

30. Bezzi P, Domercq M, Brambilla L, Galli R, Schols D, De Clercq E, Vescovi A, Bagetta G, Kollias G, Meldolesi J et al: CXCR4-activated astrocyte glutamate release via TNFalpha: amplification by microglia triggers neurotoxicity. Nat Neurosci 2001, 4(7):702-710.

31. Sriram K, O'Callaghan JP: Divergent roles for tumor necrosis factoralpha in the brain. J Neuroimmune Pharmacol 2007, 2(2):140-153.

32. McCoy MK, Tansey MG: TNF signaling inhibition in the CNS: implications for normal brain function and neurodegenerative disease. $J$ Neuroinflammation 2008, 5:45.

33. Steinmetz CC, Turrigiano GG: Tumor necrosis factor-alpha signaling maintains the ability of cortical synapses to express synaptic scaling. $J$ Neurosci 2010, 30(44):14685-14690.

34. Takei Y, Laskey R: Interpreting crosstalk between TNF-alpha and NGF: potential implications for disease. Trends Mol Med 2008, 14(9):381-388.

35. Yan M, Xia C, Niu S, Cheng C, Shao X, Shen A: The role of TNF-alpha and its receptors in the production of beta-1,4-galactosyltransferase I mRNA by rat primary type-2 astrocytes. Cell Mol Neurobiol 2008, 28(2):223-236.

36. Montalcini G, Biamino E, Bongiorno P, Caligaris F, Arnaud A: [Pathology related to the presence of a vascular shunt]. Minerva Urol Nefrol 1987, 39(2):185-188.

37. Barbeito LH, Pehar M, Cassina P, Vargas MR, Peluffo H, Viera L, Estevez $A G$, Beckman JS: $A$ role for astrocytes in motor neuron loss in amyotrophic lateral sclerosis. Brain Res Brain Res Rev 2004, 47(1-3):263274.

38. Lowry KS, Murray SS, McLean CA, Talman P, Mathers S, Lopes EC, Cheema SS: A potential role for the p75 low-affinity neurotrophin receptor in spinal motor neuron degeneration in murine and human amyotrophic lateral sclerosis. Amyotroph Lateral Scler Other Motor Neuron Disord 2001, 2(3):127-134.

39. Scorisa JM, Duobles T, Oliveira GP, Maximino JR, Chadi G: The review of the methods to obtain non-neuronal cells to study glial influence on Amyotrophic Lateral Sclerosis pathophysiology at molecular level in vitro. Acta Cir Bras 2010, 25(3):281-289.

40. Saura J, Tusell JM, Serratosa J: High-yield isolation of murine microglia by mild trypsinization. Glia 2003, 44(3):183-189.

41. Nagai $M, \operatorname{Re} D B$, Nagata $T$, Chalazonitis A, Jessell TM, Wichterle $H$, Przedborski S: Astrocytes expressing ALS-linked mutated SOD1 release factors selectively toxic to motor neurons. Nat Neurosci 2007, 10(5):615622. 
42. Gomide VC, Chadi G: The trophic factors S-100beta and basic fibroblast growth factor are increased in the forebrain reactive astrocytes of adult callosotomized rat. Brain Res 1999, 835(2):162-174.

43. Ferraiuolo L, Kirby J, Grierson AJ, Sendtner M, Shaw PJ: Molecular pathways of motor neuron injury in amyotrophic lateral sclerosis. Nat Rev Neurol 2011, 7(11):616-630.

44. Lino MM, Schneider C, Caroni P: Accumulation of SOD1 mutants in postnatal motoneurons does not cause motoneuron pathology or motoneuron disease. J Neurosci 2002, 22(12):4825-4832.

45. Pramatarova A, Laganiere J, Roussel J, Brisebois K, Rouleau GA: Neuronspecific expression of mutant superoxide dismutase 1 in transgenic mice does not lead to motor impairment. J Neurosci 2001, 21(10):33693374.

46. Wang L, Deng HX, Grisotti G, Zhai H, Siddique T, Roos RP: Wild-type SOD1 overexpression accelerates disease onset of a G85R SOD1 mouse. Hum Mol Genet 2009, 18(9):1642-1651.

47. Beers DR, Henkel JS, Xiao Q, Zhao W, Wang J, Yen AA, Siklos L, McKercher SR, Appel SH: Wild-type microglia extend survival in PU.1 knockout mice with familial amyotrophic lateral sclerosis. Proc Natl Acad Sci U S A 2006, 103(43):16021-16026.

48. Gong YH, Parsadanian AS, Andreeva A, Snider WD, Elliott JL: Restricted expression of G86R $\mathrm{Cu} / \mathrm{Zn}$ superoxide dismutase in astrocytes results in astrocytosis but does not cause motoneuron degeneration. $J$ Neurosci 2000, 20(2):660-665.

49. Yamanaka K, Chun SJ, Boillee S, Fujimori-Tonou N, Yamashita H, Gutmann $\mathrm{DH}$, Takahashi $\mathrm{R}$, Misawa $\mathrm{H}$, Cleveland DW: Astrocytes as determinants of disease progression in inherited amyotrophic lateral sclerosis. Nat Neurosci 2008, 11(3):251-253.

50. Alexianu ME, Kozovska $\mathrm{M}$, Appel $\mathrm{SH}$ : Immune reactivity in a mouse model of familial ALS correlates with disease progression. Neurology 2001, 57(7):1282-1289.

51. Gowing G, Philips T, Van Wijmeersch B, Audet JN, Dewil M, Van Den Bosch L, Billiau AD, Robberecht W, Julien JP: Ablation of proliferating microglia does not affect motor neuron degeneration in amyotrophic lateral sclerosis caused by mutant superoxide dismutase. J Neurosci 2008, 28(41):10234-10244.

52. Xiao Q, Zhao W, Beers DR, Yen AA, Xie W, Henkel JS, Appel SH: Mutant SOD1(G93A) microglia are more neurotoxic relative to wild-type microglia. J Neurochem 2007, 102(6):2008-2019.

53. Kawamura MF, Yamasaki R, Kawamura N, Tateishi T, Nagara Y, Matsushita $\mathrm{T}$, Ohyagi $\mathrm{Y}$, Kira J: Impaired recruitment of neuroprotective microglia and $T$ cells during acute neuronal injury coincides with increased neuronal vulnerability in an amyotrophic lateral sclerosis model. Exp Neurol 2012, 234(2):437-445. 
54. Liao B, Zhao W, Beers DR, Henkel JS, Appel SH: Transformation from a neuroprotective to a neurotoxic microglial phenotype in a mouse model of ALS. Exp Neurol 2012, 237(1):147-152.

55. Santello $M$, Volterra A: TNFalpha in synaptic function: switching gears. Trends Neurosci 2012, 35(10):638-647.

56. He BP, Wen W, Strong MJ: Activated microglia (BV-2) facilitation of TNFalpha-mediated motor neuron death in vitro. J Neuroimmunol 2002, 128(1-2):31-38.

57. Oberlin E, Amara A, Bachelerie F, Bessia C, Virelizier JL, ArenzanaSeisdedos F, Schwartz O, Heard JM, Clark-Lewis I, Legler DF et al: The CXC chemokine SDF-1 is the ligand for LESTR/fusin and prevents infection by T-cell-line-adapted HIV-1. Nature 1996, 382(6594):833-835.

58. Luo Y, Xue H, Pardo AC, Mattson MP, Rao MS, Maragakis NJ: Impaired SDF1/CXCR4 signaling in glial progenitors derived from SOD1(G93A) mice. J Neurosci Res 2007, 85(11):2422-2432.

59. Erta M, Quintana A, Hidalgo J: Interleukin-6, a major cytokine in the central nervous system. Int J Biol Sci 2012, 8(9):1254-1266.

60. Campbell IL, Abraham CR, Masliah E, Kemper P, Inglis JD, Oldstone MB, Mucke L: Neurologic disease induced in transgenic mice by cerebral overexpression of interleukin 6. Proc Natl Acad Sci U S A 1993, 90(21):10061-10065.

61. Tanabe K, Matsushima-Nishiwaki R, Yamaguchi S, lida H, Dohi S, Kozawa $\mathrm{O}$ : Mechanisms of tumor necrosis factor-alpha-induced interleukin-6 synthesis in glioma cells. J Neuroinflammation 2010, 7:16.

62. Colafrancesco V, Villoslada P: Targeting NGF pathway for developing neuroprotective therapies for multiple sclerosis and other neurological diseases. Arch Ital Biol 2011, 149(2):183-192.

63. Casaccia-Bonnefil P, Gu C, Khursigara G, Chao MV: p75 neurotrophin receptor as a modulator of survival and death decisions. Microsc Res Tech 1999, 45(4-5):217-224.

64. Meakin SO, Shooter EM: The nerve growth factor family of receptors. Trends Neurosci 1992, 15(9):323-331.

65. Dechant G: Chat in the trophic web: NGF activates Ret by inter-RTK signaling. Neuron 2002, 33(2):156-158.

66. Anand P, Foley P, Navsaria HA, Sinicropi D, Williams-Chestnut RE, Leigh IM: Nerve growth factor levels in cultured human skin cells: effect of gestation and viral transformation. Neurosci Lett 1995, 184(3):157-160.

67. Stuerenburg HJ, Kunze K: Tissue nerve growth factor concentrations in neuromuscular diseases. Eur J Neurol 1998, 5(5):487-490.

68. Pehar M, Cassina P, Vargas MR, Castellanos R, Viera L, Beckman JS, Estevez AG, Barbeito L: Astrocytic production of nerve growth factor in motor neuron apoptosis: implications for amyotrophic lateral sclerosis. J Neurochem 2004, 89(2):464-473. 
Figure 1.

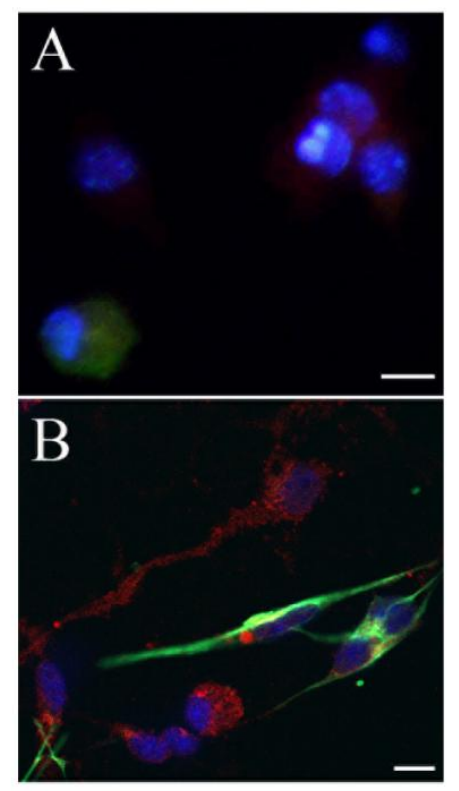


Figure 2.

Microglia

Astrocyte

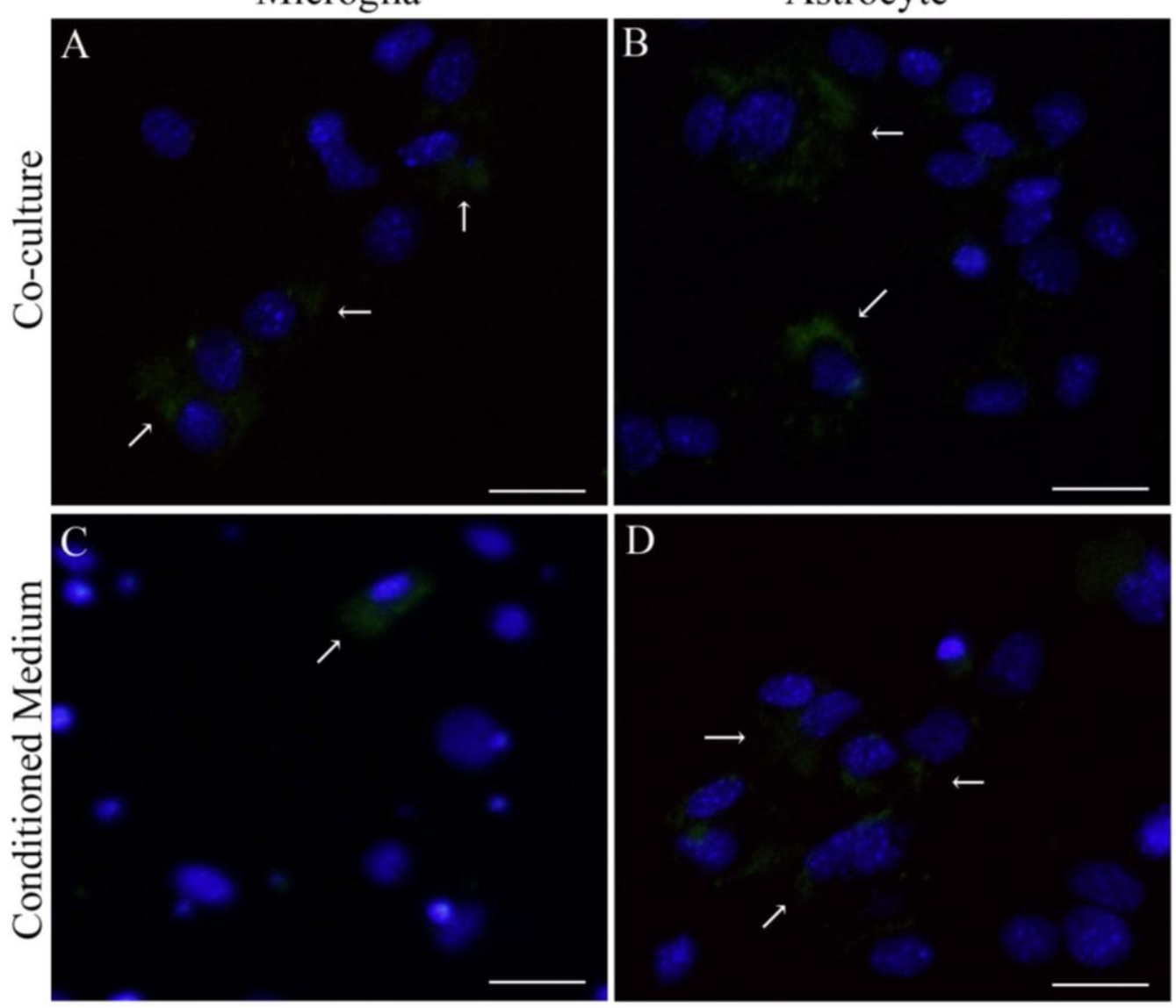


Figure 3.
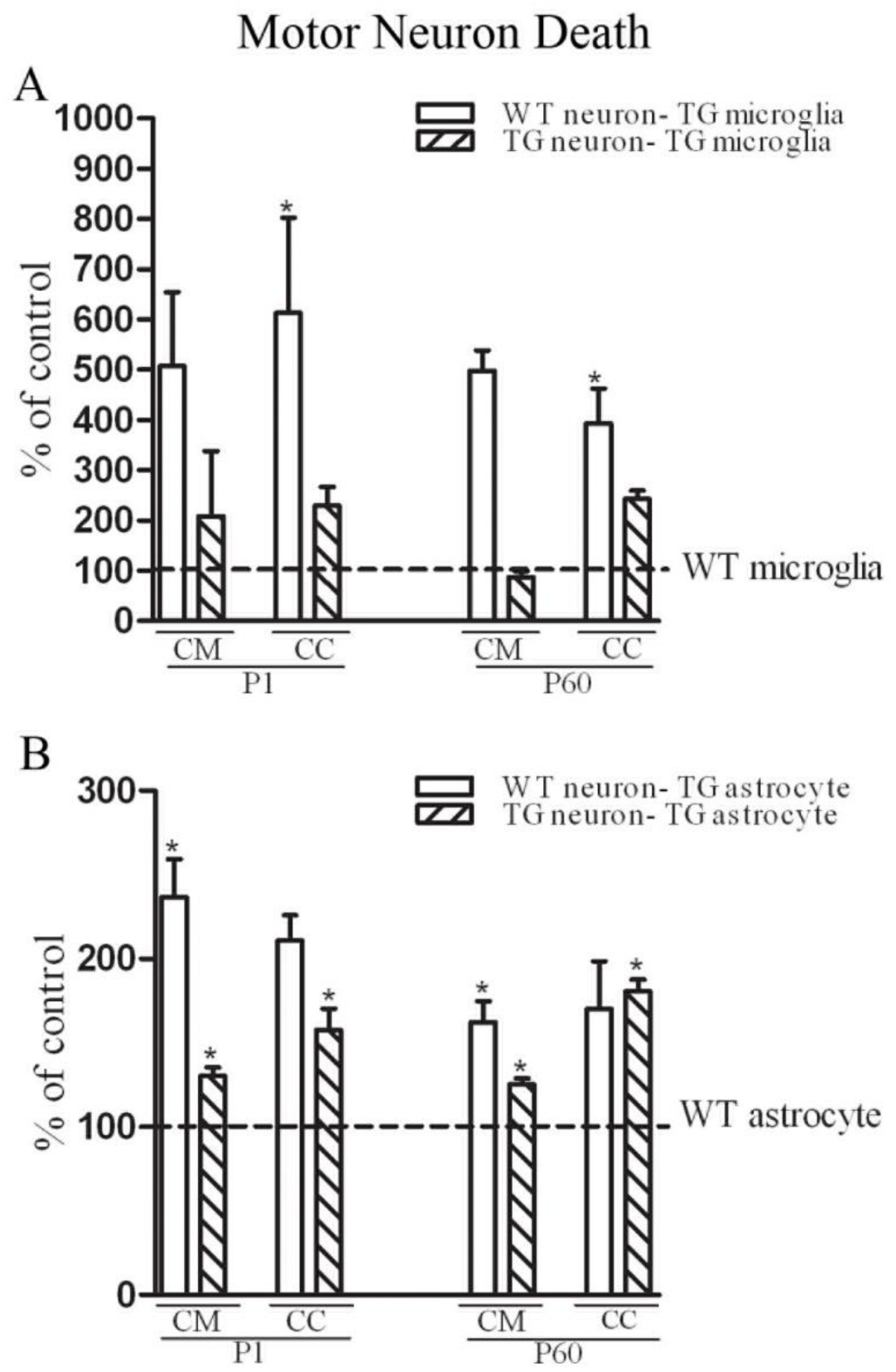
Figure 4.
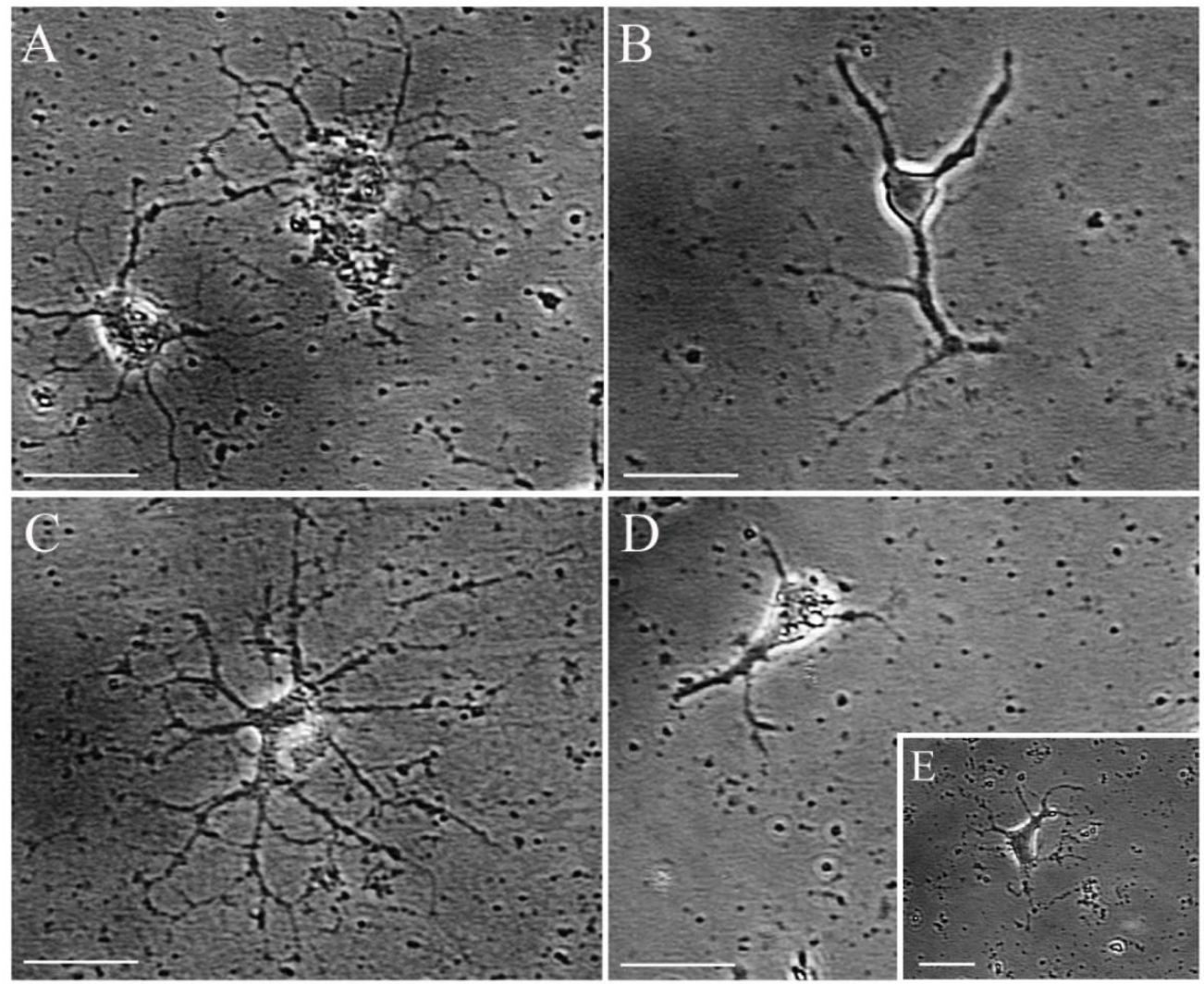
Figure 5.
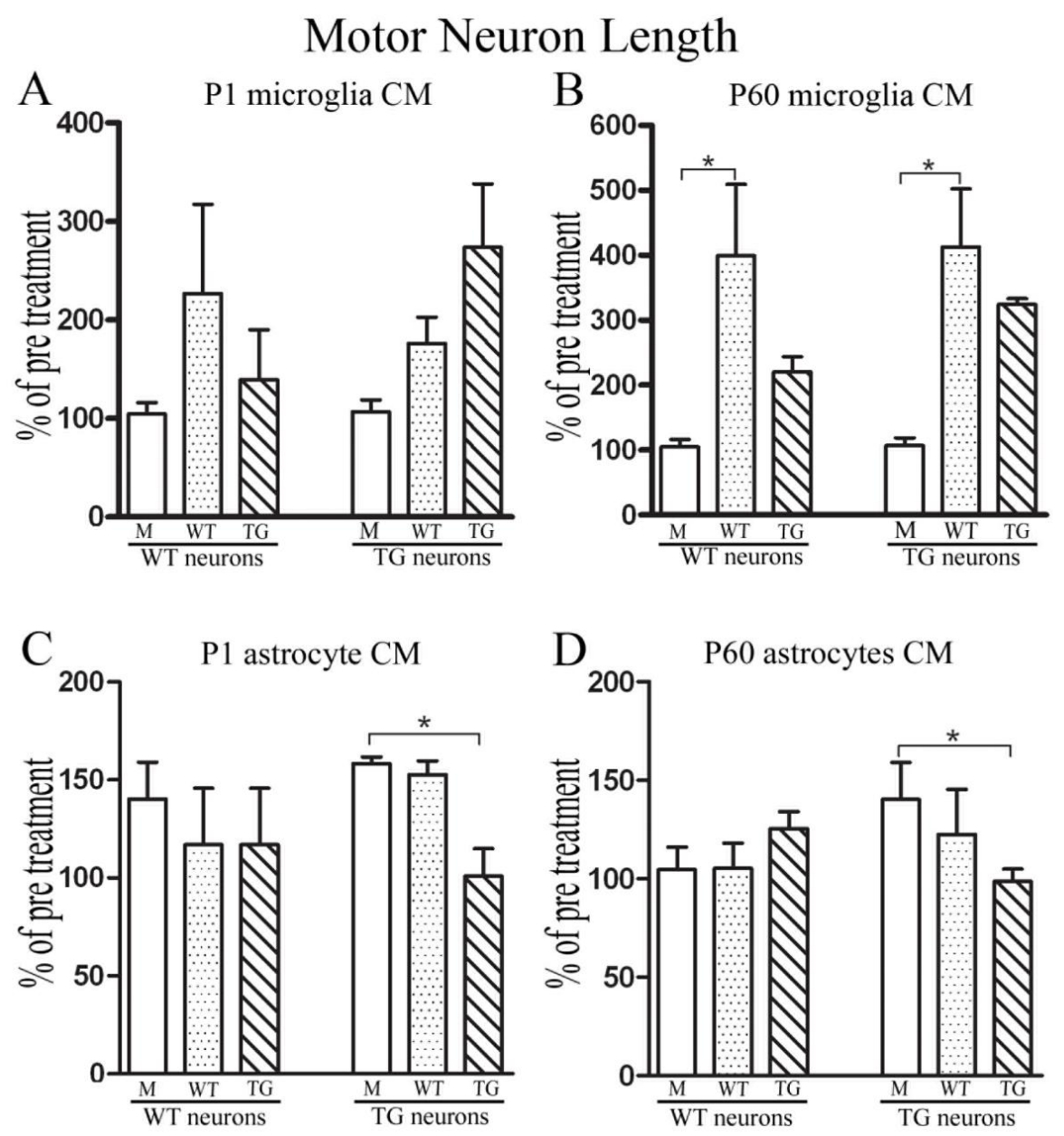
Figure 6.

Microglial conditioned media Astrocytic conditioned media

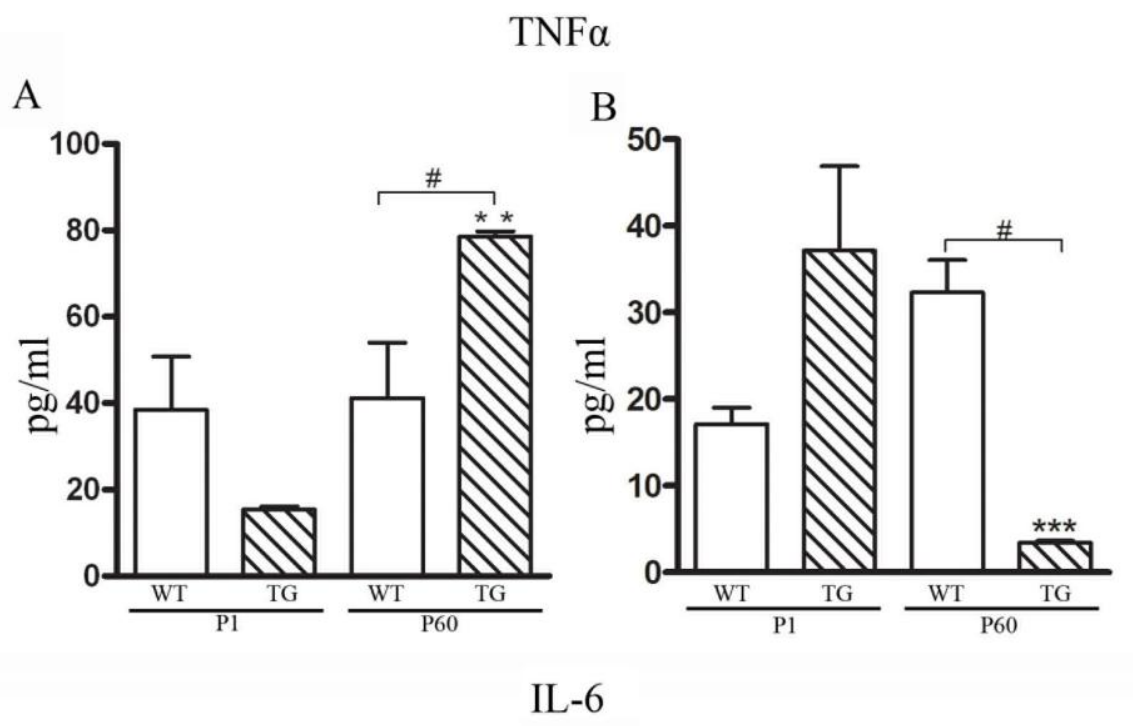

$\mathrm{C}$

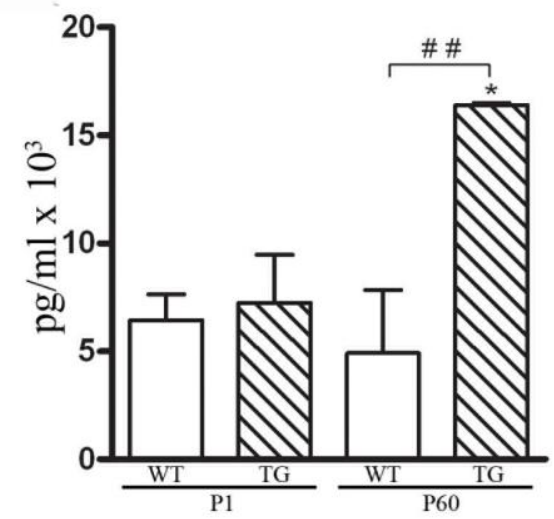

D

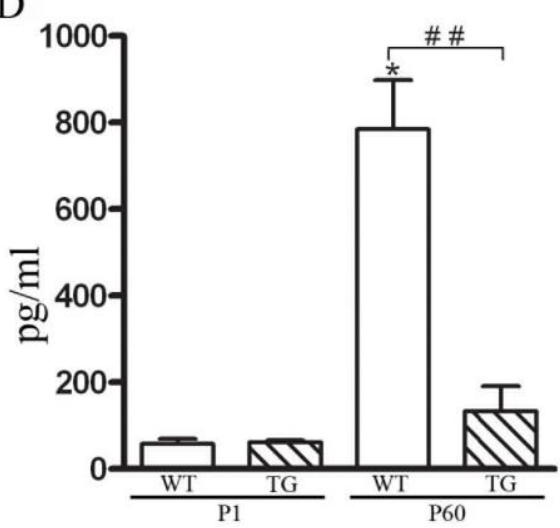

NGF
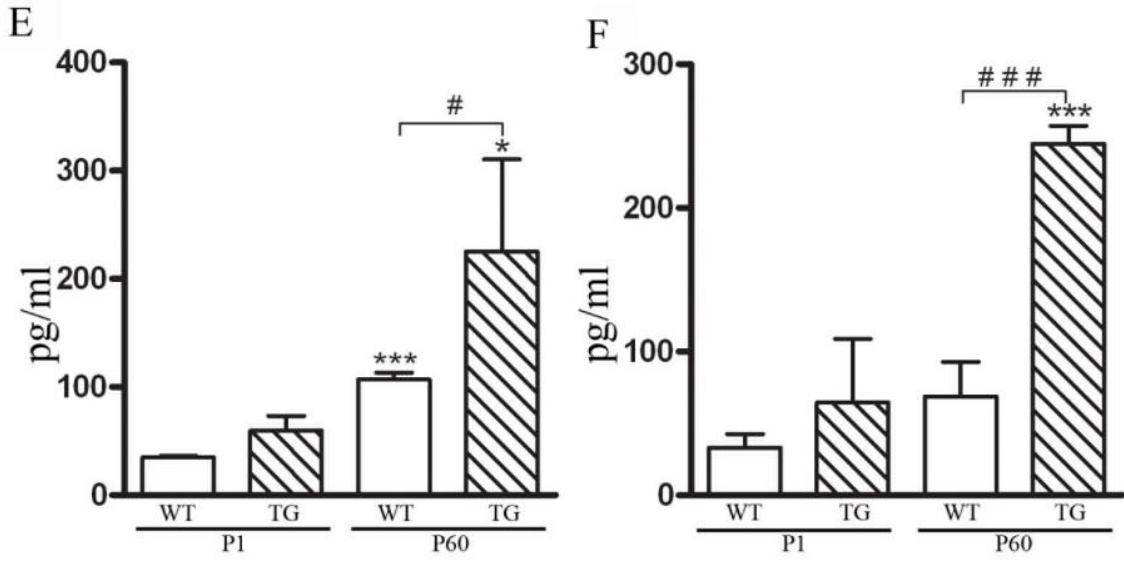